\title{
Angewandte
}

Supporting Information

\section{An Efficient Halogen-Free Electrolyte for Use in Rechargeable Magnesium Batteries**}

Oscar Tutusaus, Rana Mohtadi,* Timothy S. Arthur, Fuminori Mizuno, Emily G. Nelson, and Yulia V. Sevryugina

ange_201412202_sm_miscellaneous_information.pdf 


\section{Contents}

Page \#

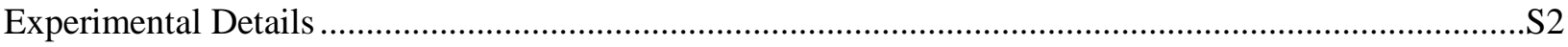

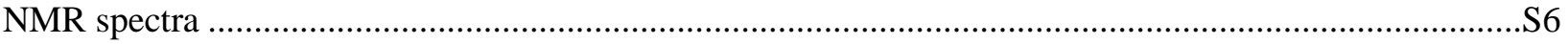

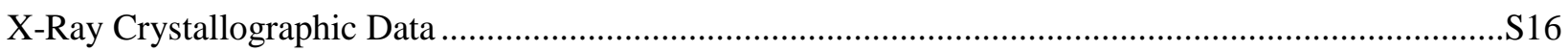

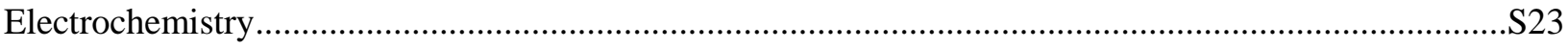

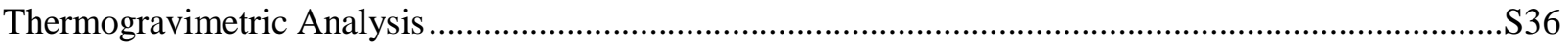

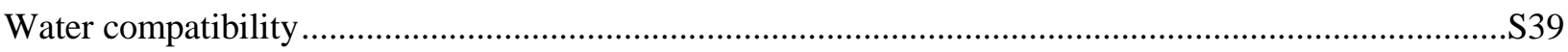

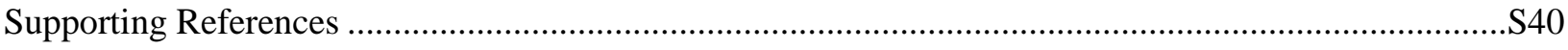




\section{Experimental Details}

\section{General Methods}

All experiments were conducted in an argon filled glovebox, unless otherwise indicated. Acetone, hexane, anhydrous $\mathrm{Et}_{2} \mathrm{O}$, magnesium carbonate trihydrate, Dowex 50WX8 50-100 ion exchange resin, and anhydrous magnesium bromide (99.995\%) were purchased from Sigma Aldrich and used as received. 4-methoxy-2,2,6,6tetramethylpiperidine-1-oxyl radical (4-MeO-TEMPO) was purchased from TCI and used as received. $\mathrm{CsCB}_{11} \mathrm{H}_{12}$ was purchased from Katchem (Czech Republic) and used as received. $\mathrm{AgCB}_{11} \mathrm{H}_{12}$ was prepared according to [1]. Neutral alumina (Brockmann I) was purchased from Sigma Aldrich and was dried for $15 \mathrm{~h}$ at $250{ }^{\circ} \mathrm{C}$ under vacuum before use. Tetrahydrofuran (THF), 1,2-dimethoxyethane (DME) and diglyme (G2) were purchased in anhydrous form from Sigma Aldrich, passed through a column containing $10 \%(\mathrm{v} / \mathrm{v})$ of dry neutral alumina, distilled from Na metal, and stored over activated $3 \AA$ molecular sieves. Triglyme (G3) and tetraglyme (G4) were purchased from Sigma Aldrich, passed through a column containing $10 \%$ (v/v) of dry neutral alumina, distilled from $\mathrm{Na}$ metal, and stirred in the presence of freshly prepared $\mathrm{Mg}$ shavings at $100{ }^{\circ} \mathrm{C}$ for $15 \mathrm{~h}$; solvents were stored with $\mathrm{Mg}$ shavings and filtered right before use. DMSO- $\mathrm{d}_{6}$ was purchased from Cambridge Isotope Labs and stored over activated $3 \AA$ molecular sieves prior to use. NMR analyses were conducted on a Varian MR400 MHz and a Varian vnmrs $700 \mathrm{MHz}$ spectrometers. ${ }^{1} \mathrm{H}$ and ${ }^{13} \mathrm{C}$ NMR spectra were referenced relative to the protic solvent resonance, and ${ }^{11} \mathrm{~B}$ spectra are referenced indirectly based on the ${ }^{1} \mathrm{H}$ spectrum. ${ }^{[2]}$ Scanning Electron Microscopy (SEM) was conducted in a Jeol-JSM-7800F Field Emission Scanning Electron Microscopy equipment FE-SEM that is equipped with an EDAX energy dispersive X-ray spectroscopy (EDS) system. Prior to each SEM/EDS analysis, in Ar glove box, the sample was loaded in an air-tight sample holder to prevent any exposure to ambient air during sample transfer.

\section{Synthetic Protocols}

Synthesis of $\left[\mathrm{Mg}\left(\mathrm{H}_{2} \mathrm{O}\right)_{6}\right]\left(\mathrm{CB}_{11} \mathrm{H}_{12}\right)_{2}(2): \mathrm{CsCB}_{11} \mathrm{H}_{12}(500 \mathrm{mg}, 1.81 \mathrm{mmol})$ was dissolved in $\mathrm{H}_{2} \mathrm{O}(10 \mathrm{~mL})$ under ambient conditions with gentle heating and the warm solution was passed through a cation exchange resin column (acidic form, $2 \times 7 \mathrm{~mL}$ ). The resulting solution of the free acid was neutralized with excess $\mathrm{MgCO}_{3} \cdot 3 \mathrm{H}_{2} \mathrm{O}$ ( $250 \mathrm{mg}, 2 \mathrm{eq}$ ). The suspension was vigorously stirred for 10 minutes and filtered. The filtrate was evaporated to dryness and the white solid was extracted with acetone $(2 \times 10 \mathrm{~mL})$. The solvent was concentrated to $5 \mathrm{~mL}$, then $\mathrm{H}_{2} \mathrm{O}(5 \mathrm{~mL})$ was added and the solution was evaporated to dryness. The white solid was added $\mathrm{H}_{2} \mathrm{O}(5 \mathrm{~mL})$, the resulting cloudy suspension was filtered and evaporated to dryness to provide 2 as a white solid. Yield: $355 \mathrm{mg}$ (94\%). ${ }^{1} \mathrm{H}\left\{{ }^{11} \mathrm{~B}\right\}$ NMR (399.54 MHz, [D $]$ DMSO): 3.37 (s, 6H; $\left.\mathrm{H}_{2} \mathrm{O}\right), 2.38(\mathrm{~s}, 1 \mathrm{H} ; \mathrm{CH}), 1.56$ (s, 6H; BH), $1.41(\mathrm{~s}$, $5 \mathrm{H} ; \mathrm{BH}) ;{ }^{11} \mathrm{~B}$ NMR $\left(128.19 \mathrm{MHz},\left[\mathrm{D}_{6}\right] \mathrm{DMSO}\right):-7.0\left(\mathrm{~d}, 1 \mathrm{~B},{ }^{2} \mathrm{~J}(\mathrm{BH})=135 \mathrm{~Hz}\right),-13.3\left(\mathrm{~d}, 5 \mathrm{~B},{ }^{2} \mathrm{~J}(\mathrm{BH})=135 \mathrm{~Hz}\right),-$ $16.2\left(\mathrm{~d}, 5 \mathrm{~B},{ }^{2} \mathrm{~J}(\mathrm{BH})=150 \mathrm{~Hz}\right) ;{ }^{13} \mathrm{C}\left\{{ }^{1} \mathrm{H}\right\} \mathrm{NMR}\left(100.47 \mathrm{MHz},\left[\mathrm{D}_{6}\right] \mathrm{DMSO}\right): 50.74$ (s, CH); Elemental analysis calculated for $\mathrm{C}_{2} \mathrm{H}_{36} \mathrm{~B}_{22} \mathrm{MgO}_{6}$ : C 5.74, $\mathrm{H}$ 8.67. Found: C 6.52, $\mathrm{H}$ 8.74.

Synthesis of $\left[\mathrm{Mg}(\mathrm{THF})_{6}\right]\left(\mathrm{CB}_{11} \mathrm{H}_{12}\right)_{2}(3)$ : A solution of $\mathrm{AgCB}_{11} \mathrm{H}_{12}(5.04 \mathrm{~g}, 20.1 \mathrm{mmol})$ in $\mathrm{THF}(12 \mathrm{~mL})$ was added to a stirring solution of anhydrous $\mathrm{MgBr}_{2}(1.826 \mathrm{~g}, 9.92 \mathrm{mmol})$ in THF (43 mL). The suspension was stirred for $2.5 \mathrm{~h}$ and the solid was collected by filtration, washed with THF $(2 \times 10 \mathrm{~mL})$ and dried under vacuum. Obtained $10.615 \mathrm{~g}(96 \%)$ of a pale yellow solid composed of a mixture 3:AgBr $(1: 2) .{ }^{1} \mathrm{H}\left\{{ }^{11} \mathrm{~B}\right\} \mathrm{NMR}(399.54$ $\left.\mathrm{MHz},\left[\mathrm{D}_{6}\right] \mathrm{DMSO}\right): 3.60$ (m, 12H; $\left.\mathrm{OCH}_{2}\right), 2.38$ (s, 1H; CH), $1.76\left(\mathrm{~m}, 12 \mathrm{H} ; \mathrm{CH}_{2}\right), 1.56$ (s, 6H; BH), 1.41 (s, 5H; $\mathrm{BH}) ;{ }^{11} \mathrm{~B}$ NMR $\left(128.19 \mathrm{MHz},\left[\mathrm{D}_{6}\right] \mathrm{DMSO}\right):-7.0\left(\mathrm{~d}, 1 \mathrm{~B},{ }^{2} \mathrm{~J}(\mathrm{BH})=133 \mathrm{~Hz}\right),-13.3\left(\mathrm{~d}, 5 \mathrm{~B},{ }^{2} \mathrm{~J}(\mathrm{BH})=135 \mathrm{~Hz}\right),-16.2$ $\left(\mathrm{d}, 5 \mathrm{~B},{ }^{2} \mathrm{~J}(\mathrm{BH})=150 \mathrm{~Hz}\right) ;{ }^{13} \mathrm{C}\left\{{ }^{1} \mathrm{H}\right\} \mathrm{NMR}\left(100.47 \mathrm{MHz},\left[\mathrm{D}_{6}\right] \mathrm{DMSO}\right): 67.01\left(\mathrm{~s}, \mathrm{OCH}_{2}\right), 50.67(\mathrm{~s}, \mathrm{CH}), 25.12(\mathrm{~s}$, $\mathrm{CH}_{2}$ ). 
Synthesis of $\left[\mathrm{Mg}(\mathrm{DME})_{3}\right]\left(\mathrm{CB}_{11} \mathrm{H}_{12}\right)_{2}$ (4): Pale yellow solid containing 3:AgBr (1:2) (10.615 g, $9.49 \mathrm{mmol}$ of 3) was added DME $(100 \mathrm{~mL})$ in a $250 \mathrm{~mL}$ Erlenmeyer flask, and the mixture was stirred while cooled externally with an external acetone $/ \mathrm{CO}_{2}$ bath. After 15 minutes, the mixture reached a temperature of $-15^{\circ} \mathrm{C}$. At that point, the solid was filtered off and washed with cold DME $(2 \times 5 \mathrm{~mL})$. Filtrate and washings were combined and stored at room temperature overnight, during which time some crystals precipitated. The mixture was gently heated to $60{ }^{\circ} \mathrm{C}$ without stirring for $3 \mathrm{~h}$, and more solid crystallized out. The white crystalline solid was collected by filtration, washed with hot DME $(5 \mathrm{~mL}+2 \mathrm{~mL})$ and dried under vacuum. Yield: $4.896 \mathrm{~g}(89 \%) .{ }^{1} \mathrm{H}\left\{{ }^{11} \mathrm{~B}\right\} \mathrm{NMR}$ (399.54 MHz, [D 6 ]DMSO): 3.42 (s, 6H; $\mathrm{CH}_{2}$ ), 3.23 (s, 9H; $\left.\mathrm{CH}_{3}\right), 2.39$ (s, 1H; CH), 1.56 (s, 6H; BH), 1.41 (s, 5H; $\mathrm{BH}) ;{ }^{11} \mathrm{~B}$ NMR $\left(128.19 \mathrm{MHz},\left[\mathrm{D}_{6}\right] \mathrm{DMSO}\right):-7.0\left(\mathrm{~d}, 1 \mathrm{~B},{ }^{2} \mathrm{~J}(\mathrm{BH})=133 \mathrm{~Hz}\right),-13.3\left(\mathrm{~d}, 5 \mathrm{~B},{ }^{2} \mathrm{~J}(\mathrm{BH})=135 \mathrm{~Hz}\right),-16.2$ $\left(\mathrm{d}, 5 \mathrm{~B},{ }^{2} \mathrm{~J}(\mathrm{BH})=148 \mathrm{~Hz}\right) ;{ }^{13} \mathrm{C}\left\{{ }^{1} \mathrm{H}\right\} \mathrm{NMR}\left(100.47 \mathrm{MHz},\left[\mathrm{D}_{6}\right] \mathrm{DMSO}\right): 71.09\left(\mathrm{~s}, \mathrm{CH}_{2}\right), 58.07\left(\mathrm{~s}, \mathrm{CH}_{3}\right), 50.76(\mathrm{~s}, \mathrm{CH})$; Elemental analysis calculated for $\mathrm{C}_{14} \mathrm{H}_{54} \mathrm{~B}_{22} \mathrm{MgO}_{6}$ : C 28.96, $\mathrm{H}$ 9.37. Found: $\mathrm{C} 28.93$, $\mathrm{H}$ 9.96. While the solid yields X-ray quality crystals of $\mathbf{4}$, and appears pure by NMR and elemental analysis, further purification is required for electrochemical grade purity.

Purification of 4 by "Inverse Recrystallization": 4 (3.05 g) was suspended in $20 \mathrm{~mL}$ of DME at room temperature, and the suspension was cooled down with an external acetone $/ \mathrm{CO}_{2}$ bath while stirring. After about 15 minutes, the solid dissolved, even though in some instances small amounts of grey particles remain insoluble. Any insoluble solid was filtered off and the filtrate was immediately heated up to $60{ }^{\circ} \mathrm{C}$. After 45 mins, the suspension was filtered using only gentle suction and filtration was stopped when the solid was still somewhat damp to avoid its redissolution due to cooling. It was then washed with hot DME $(8 \mathrm{~mL})$, and transferred while damp to a flask and connected to vacuum until dry. Obtained $2.96 \mathrm{~g}(97 \%)$ of $\mathbf{4}$ as a white microcrystalline solid.

Synthesis of $\left[\mathrm{Mg}(\mathrm{G} 2)_{2}\right]\left(\mathrm{CB}_{11} \mathrm{H}_{12}\right)_{2} \cdot G 2$ (5): Pale yellow solid containing 3:AgBr (1:2) (76.6 mg, $\left.68.5 \mu \mathrm{mol}\right)$ was extracted with diglyme $(3 \times 1 \mathrm{~mL})$. Hexane $(3 \mathrm{~mL})$ was added to the combined diglyme extracts to precipitate a white solid, which was collected by filtration, washed with excess hexane and dried under vacuum. Yield: 42.1 mg (86\%). ${ }^{1} \mathrm{H}\left\{{ }^{11} \mathrm{~B}\right\}$ NMR (399.54 MHz, [D 6 DMSO): 3.50 (m, 6H; $\left.\mathrm{CH}_{2}\right), 3.42$ (m, 6H; $\left.\mathrm{CH}_{2}\right), 3.24\left(\mathrm{~s}, 9 \mathrm{H} ; \mathrm{CH}_{3}\right)$, 2.39 (s, 1H; CH), 1.56 (s, 6H; BH), 1.41 (s, 5H; BH); ${ }^{11} \mathrm{~B}$ NMR (224.51 MHz, [D 6 DMSO): -7.0 (d, 1B, $\left.{ }^{2} \mathrm{~J}(\mathrm{BH})=131 \mathrm{~Hz}\right),-13.3\left(\mathrm{~d}, 5 \mathrm{~B},{ }^{2} \mathrm{~J}(\mathrm{BH})=133 \mathrm{~Hz}\right),-16.2\left(\mathrm{~d}, 5 \mathrm{~B},{ }^{2} \mathrm{~J}(\mathrm{BH})=148 \mathrm{~Hz}\right) ;{ }^{13} \mathrm{C}\left\{{ }^{1} \mathrm{H}\right\} \mathrm{NMR}(175.97 \mathrm{MHz}$, [D $\mathrm{D}_{6}$ DMSO): $71.28\left(\mathrm{~s}, \mathrm{CH}_{2}\right), 69.57\left(\mathrm{~s}, \mathrm{CH}_{2}\right), 58.05\left(\mathrm{~s}, \mathrm{CH}_{3}\right), 50.70(\mathrm{~s}, \mathrm{CH})$; Elemental analysis calculated for $\mathrm{C}_{20} \mathrm{H}_{66} \mathrm{~B}_{22} \mathrm{MgO}_{9}$ : C 33.70, H 9.33. Found: C 33.51, H 9.42.

\section{Electrochemical Analysis}

All electrochemical experiments were conducted using a Bio-Logic VMP3 multi-channel potentiostat. A fresh electrolyte solution was prepared for each experiment. Working electrodes were Pt (1.6 mm dia.), Al (2 mm dia.), $\mathrm{Ni}$ (3 mm dia.), glassy carbon (GC, $3 \mathrm{~mm}$ dia.), and 316-stainless steel (316SS; $2 \mathrm{~mm}$ dia.) disks, purchased from BASi and were extensively polished between each use. Unless otherwise stated, counter and reference electrodes were magnesium ribbons. Cyclic voltammetry and linear sweep voltammetry experiments were conducted at a scan rate of $5 \mathrm{mV} / \mathrm{sec}$. Oxidation onset potentials and coulombic efficiencies were determined using previously described methods. ${ }^{[3]}$ Cyclic voltammetry experiments of 4-MeO-TEMPO used ferrocene as an internal reference and were carried out in a modified three electrode set-up with a Pt disk working electrode, a Pt wire counter electrode, and a Ag wire quasi-reference electrode. Conductivity measurements were conducted using a Pt electrode symmetrical cell. The cell constant was obtained by cell calibration using potassium chloride and was used to calculate the conductivity of the electrolyte. The $0.2 \mathrm{M}(2: 1) \mathrm{PhMgCl}_{\mathrm{AlCl}} / \mathrm{THF}$ (APC) electrolyte and Chevrel phase $\mathrm{Mo}_{6} \mathrm{~S}_{8}$ cathode were prepared as was described in literature. ${ }^{[4]}$ 
General procedure for the preparation of 0.75 M magnesium monocarborane (MMC) salt solutions in G3 or G4: to obtain approx. $1 \mathrm{~mL}$ of MMC/G3 or MMC/G4 electrolyte solutions, recrystallized 4 (363 mg, $625 \mu \mathrm{mol}) \mathrm{was}$ added G3 or G4 $(833 \mu \mathrm{L})$ and the mixture was stirred for 10 minutes. The clear solution thus obtained was further stirred under vacuum for 10 minutes to remove all DME.

\section{Chronoamperometry experiments}

Chronoamperometry experiments were conducted using a SB-1A (EC Frontier Inc, Japan) battery evaluation cell with a 316SS disk working electrode (19 mm dia.), a Mg disk counter electrode, and a Mg wire as reference electrode. EPMD gaskets (13 mm dia.) were used to limit the area exposed to electrolyte solution on the working and counter electrodes to $1.33 \mathrm{~cm}^{2}$. In a typical test run, a predetermined constant voltage was applied on the 316SS disk for $48 \mathrm{~h}$. The cell was deconstructed and the 316SS disk was washed first with G4, and then with THF. The 316SS disk was then analyzed by SEM, EDS and laser microscope. When $3.5 \mathrm{~V}$ were applied, the electrolyte solution was sampled before and after chronoamperometry experiment to determine $\mathrm{Fe}, \mathrm{Ni}$ and $\mathrm{Cr}$ contents via ICP analysis.

\section{Galvanostatic Deposition}

Galvanostatic deposition of magnesium was conducted using a two electrode cell with a platinum disk working electrode (15 $\mathrm{mm}$ dia.) and a magnesium disk counter electrode (15 mm diameter). A constant current corresponding to a potential of $-0.6 \mathrm{~V}$ (vs. $\mathrm{Mg}$ ) was applied for $40 \mathrm{~h}$, before the cell was deconstructed, and platinum disk was soaked in anhydrous G4, followed by rinsing in anhydrous THF. The deposits on the Pt disk were then analyzed by XRD and SEM to verify the deposition of magnesium.

\section{Powder X-ray Diffraction}

X-ray diffraction was conducted in Rigaku SmartLab® equipped with $\mathrm{Cu} \mathrm{K}$ X-ray source. Prior to the X-ray analysis, the platinum disk obtained following galvanostatic deposition of magnesium was carefully covered with $8 \mu \mathrm{m}$ Kapton film to prevent exposure to air. All experiments were run at $0.3 \% \mathrm{~min}$ scan rate and $0.02^{\circ}$ step size. The ex-situ XRD results shown in figure S45 were run for the pristine, as prepared, Chevrel phase electrode and following the first discharge. The discharged battery was disassembled under Ar in a glove box and the cathode electrode was completely rinsed with THF and dried under vacuum at $25^{\circ} \mathrm{C}$ for 12 hours to remove any residual solvent in the electrode. The discharged electrode was then sealed in an air-free sample holder with beryllium window during the XRD analysis.

\section{Battery Testing}

Battery experiments were conducted in 2032 coin cell using a magnesium disk anode, a glass microfiber filter as separator and either Chevrel phase $\left(\mathrm{Mo}_{6} \mathrm{~S}_{8}\right)$ cathode or $\alpha-\mathrm{MnO}_{2}$ cathode. The $\mathrm{Mg}$ anode with 15 mm in diameter was mechanically polished prior to cell assembly. $100 \mu \mathrm{l}$ of as-made electrolytes (APC or MMC/G4) were immersed in the separator (19 $\mathrm{mm}$ dia. and $435 \mu \mathrm{m}$ in thickness). The cathodes were prepared by mixing $70 \mathrm{wt} \%$ active material, 15-20 wt\% carbon black and 10-15 wt\% poly(tetrafluoroethylene), pressed into a 100-120 $\mu \mathrm{m}$ thick pellet, and vacuum dried at $120{ }^{\circ} \mathrm{C}$ for $12 \mathrm{~h}$. The cathode pellets were cut out from the sheet at $15 \mathrm{~mm}$ diameter. The cell was assembled in the glove box $\left(\mathrm{H}_{2} \mathrm{O}\right.$ and $\left.\mathrm{O}_{2}<0.1 \mathrm{ppm}\right)$ and run at room temperature under a constant current density. 
The TGA experiments were conducted in a STA 409 PC Simultaneous Thermal Analyzer from Netzsch Instruments, operated in an argon-filled glovebox. Experiments used 20-30 mg samples with a heating rate of $2{ }^{\circ} \mathrm{C} / \mathrm{min}$ from ambient to $500{ }^{\circ} \mathrm{C}$ and constant argon flow.

\section{Water Compatibility Experiment}

A 0.75 M MMC/G4 electrolyte solution $(0.5 \mathrm{~mL})$ was placed in a glass shell containing a stir bar and water was added dropwise without stirring. After 35 seconds, an equal volume of water was added, which stayed as an immiscible layer above the MMC/G4 solution. The biphasic mixture was then stirred and quickly became a colorless solution. Mixing was continued overnight. No reaction was observed during addition nor when the solutions mixed. 
NMR spectra

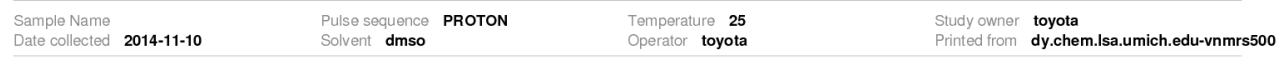

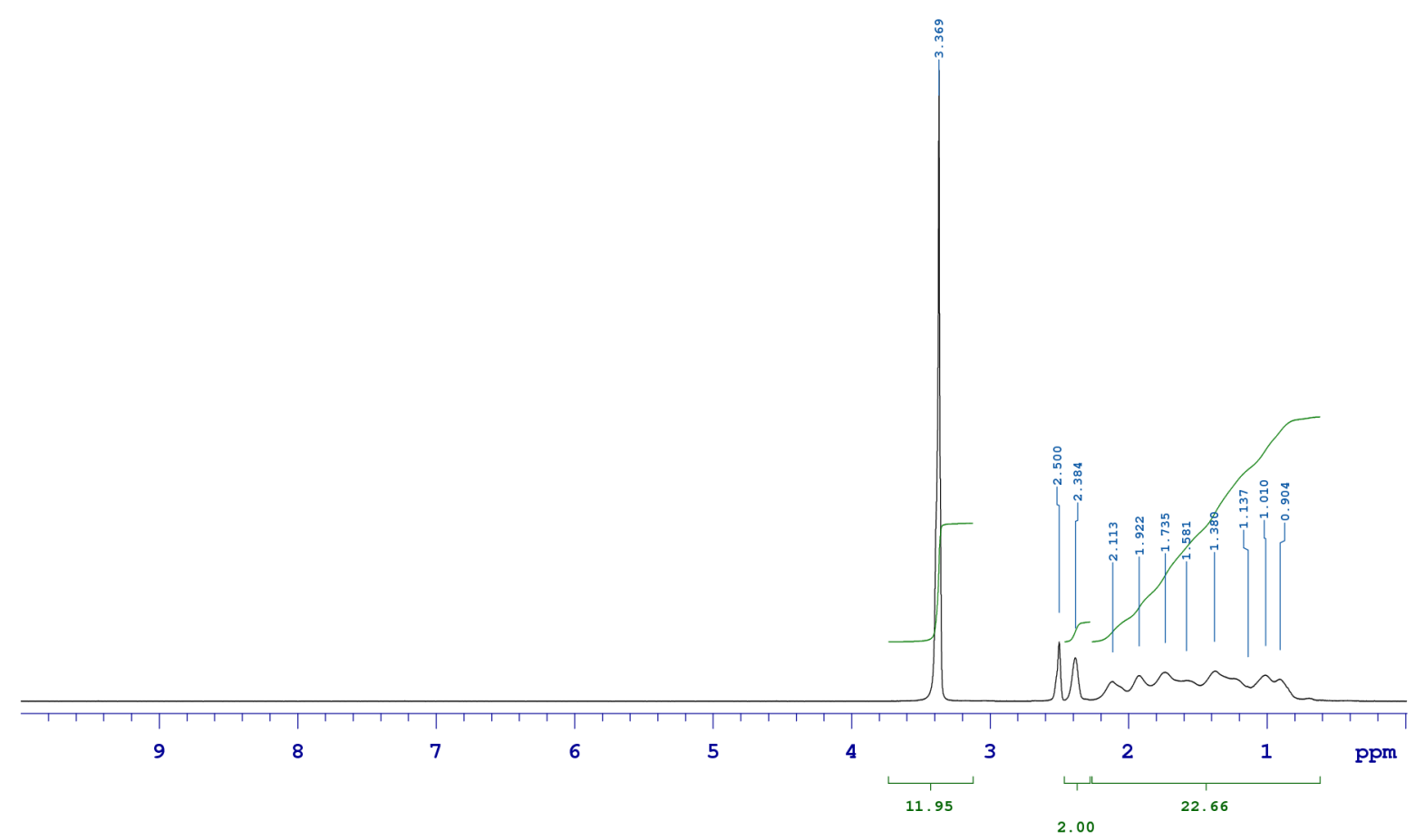

Figure S1. ${ }^{1} \mathrm{H}$ NMR (399.54 MHz, DMSO-d 6 ) of $\left[\mathrm{Mg}\left(\mathrm{H}_{2} \mathrm{O}\right)_{6}\right]\left(\mathrm{CB}_{11} \mathrm{H}_{12}\right)_{2}(2)$.

\begin{tabular}{|c|c|}
\hline $\begin{array}{l}\text { Sample Name } \\
\text { Date collected } \mathbf{2 0 1 4 - 1 1 - 1 0}\end{array}$ & $\begin{array}{l}\text { Pulse sequence PRoton } \\
\text { Solvent dmso }\end{array}$ \\
\hline
\end{tabular}

Study owner toyota

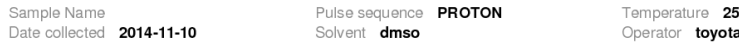

Printed from dy.chem.lsa.umich.edu-vnmrs500

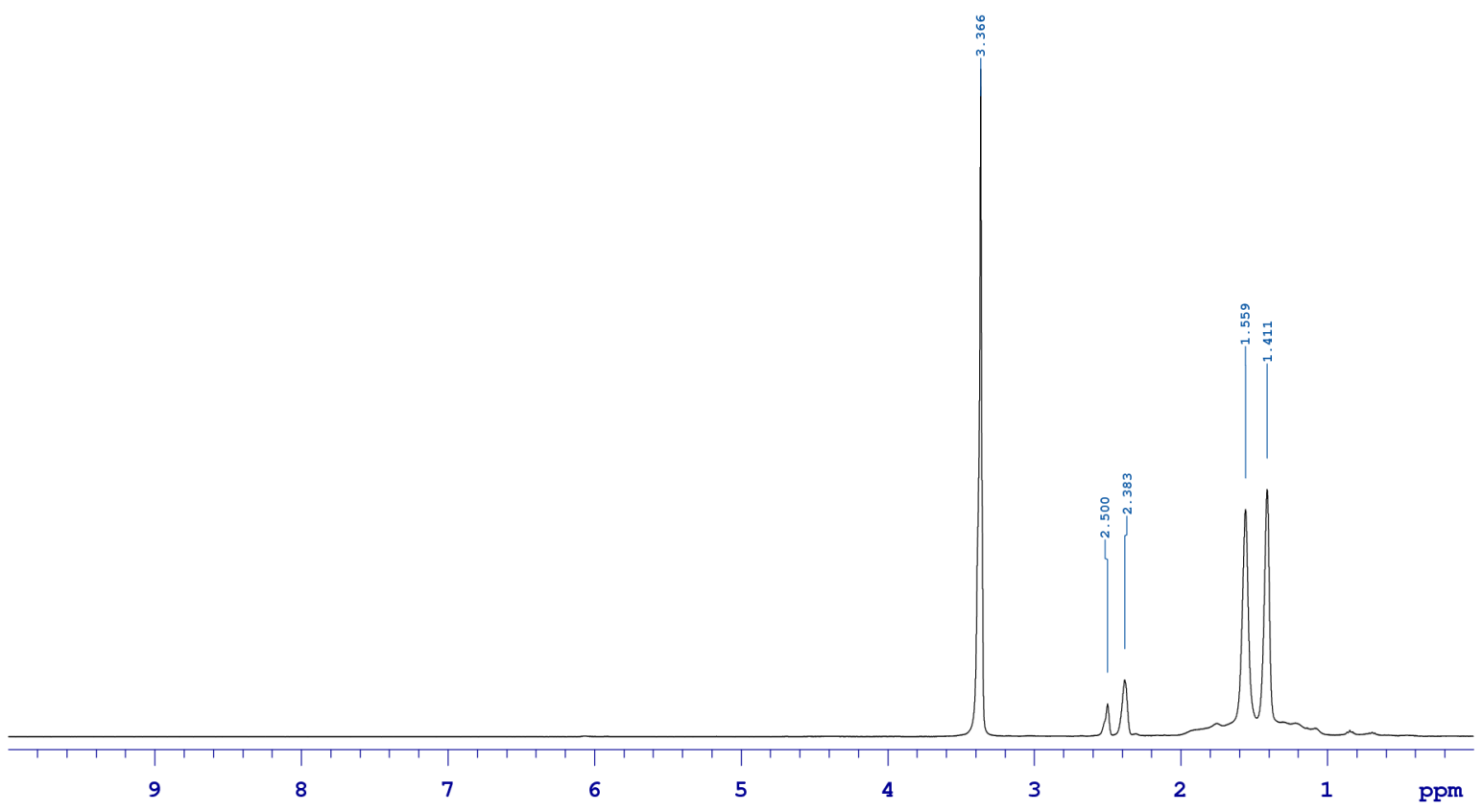

Figure S2. ${ }^{1} \mathrm{H}\left\{{ }^{11} \mathrm{~B}\right\}$ NMR (399.54 MHz, DMSO-d 6 of $\left[\mathrm{Mg}\left(\mathrm{H}_{2} \mathrm{O}\right)_{6}\right]\left(\mathrm{CB}_{11} \mathrm{H}_{12}\right)_{2}(2)$. 


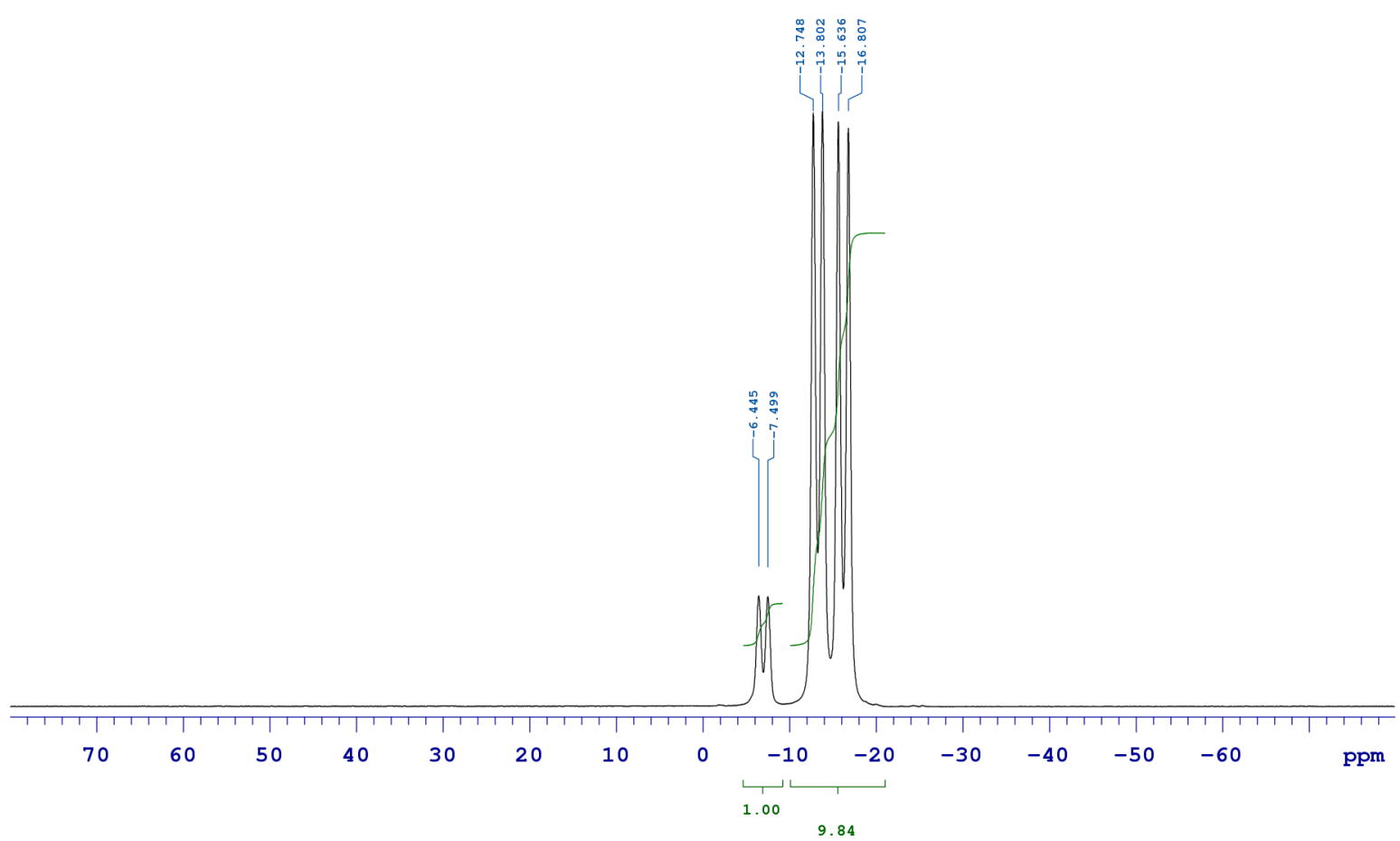

Figure S3. ${ }^{11}$ B NMR $\left(128.19 \mathrm{MHz}\right.$, DMSO- $\left.\mathrm{d}_{6}\right)$ of $\left[\mathrm{Mg}\left(\mathrm{H}_{2} \mathrm{O}\right)_{6}\right]\left(\mathrm{CB}_{11} \mathrm{H}_{12}\right)_{2}(\mathbf{2})$.

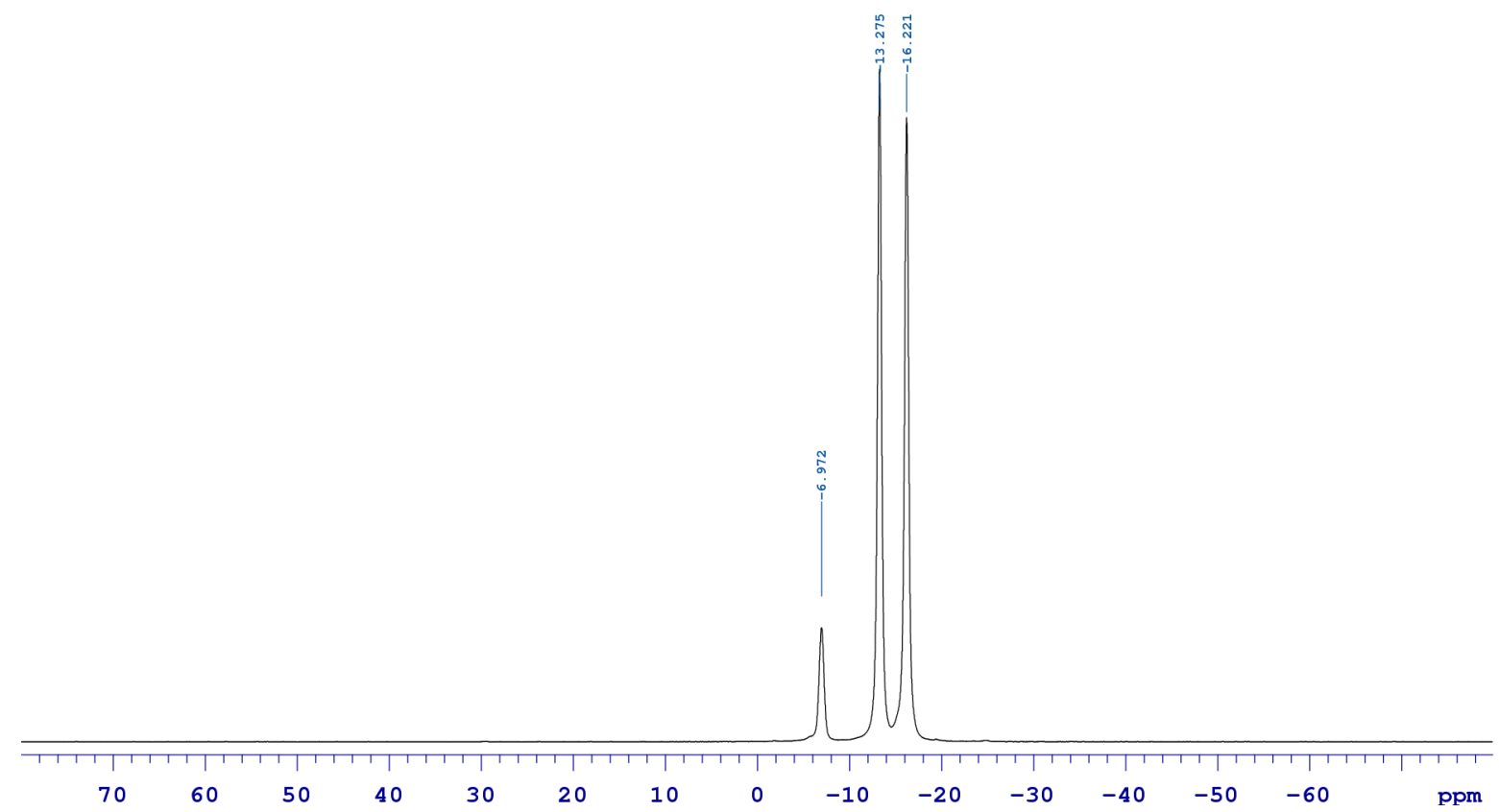

Figure S4. ${ }^{11} \mathrm{~B}\left\{{ }^{1} \mathrm{H}\right\}$ NMR $\left(128.19 \mathrm{MHz}\right.$, DMSO-d $\left.\mathrm{d}_{6}\right)$ of $\left[\mathrm{Mg}\left(\mathrm{H}_{2} \mathrm{O}\right)_{6}\right]\left(\mathrm{CB}_{11} \mathrm{H}_{12}\right)_{2}(\mathbf{2})$. 


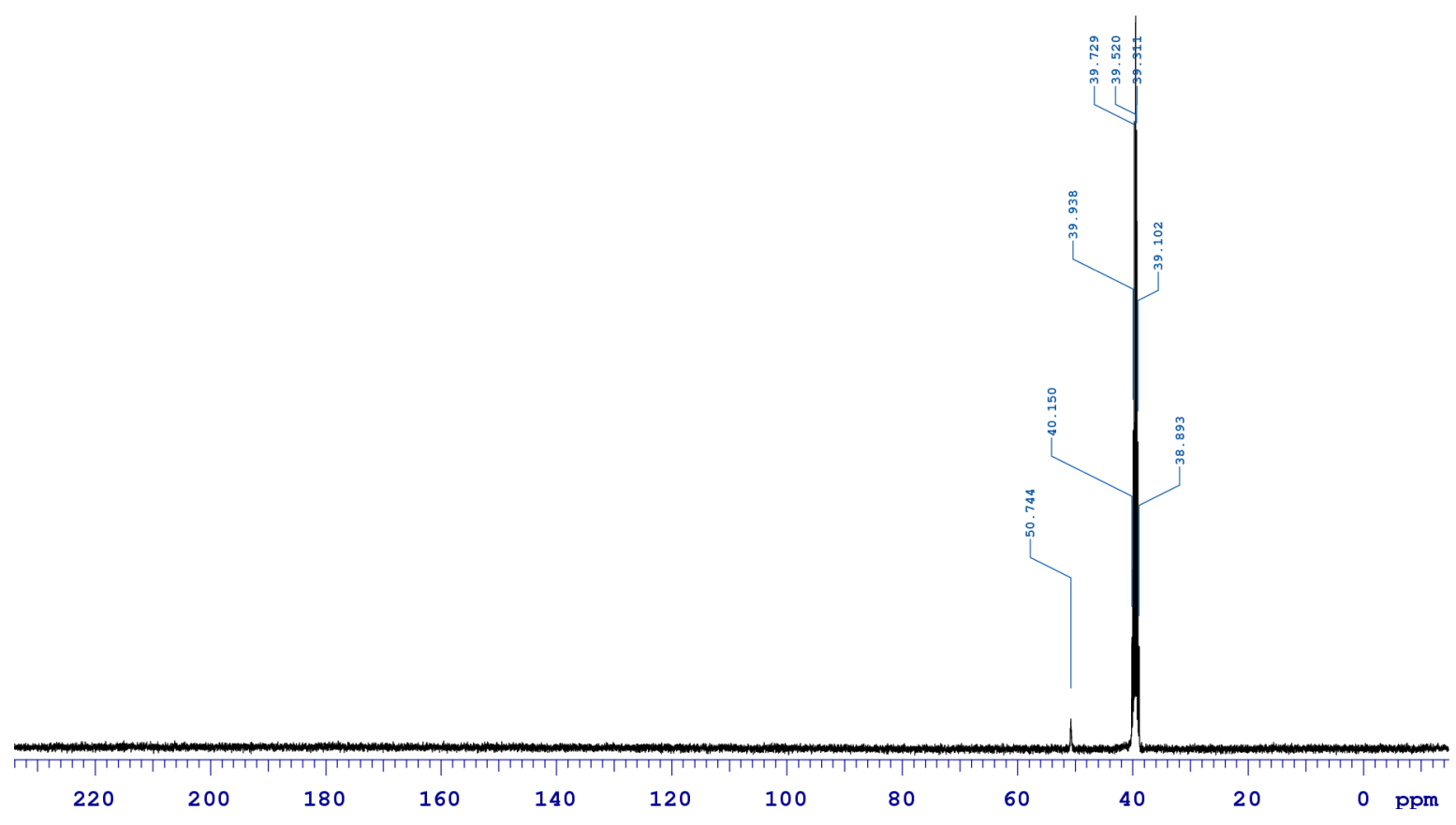

Figure S5. ${ }^{13} \mathrm{C}$ NMR $\left(100.47 \mathrm{MHz}\right.$, DMSO-d $\left.\mathrm{d}_{6}\right)$ of $\left[\mathrm{Mg}\left(\mathrm{H}_{2} \mathrm{O}\right)_{6}\right]\left(\mathrm{CB}_{11} \mathrm{H}_{12}\right)_{2}(\mathbf{2})$.

Agilent Technologies

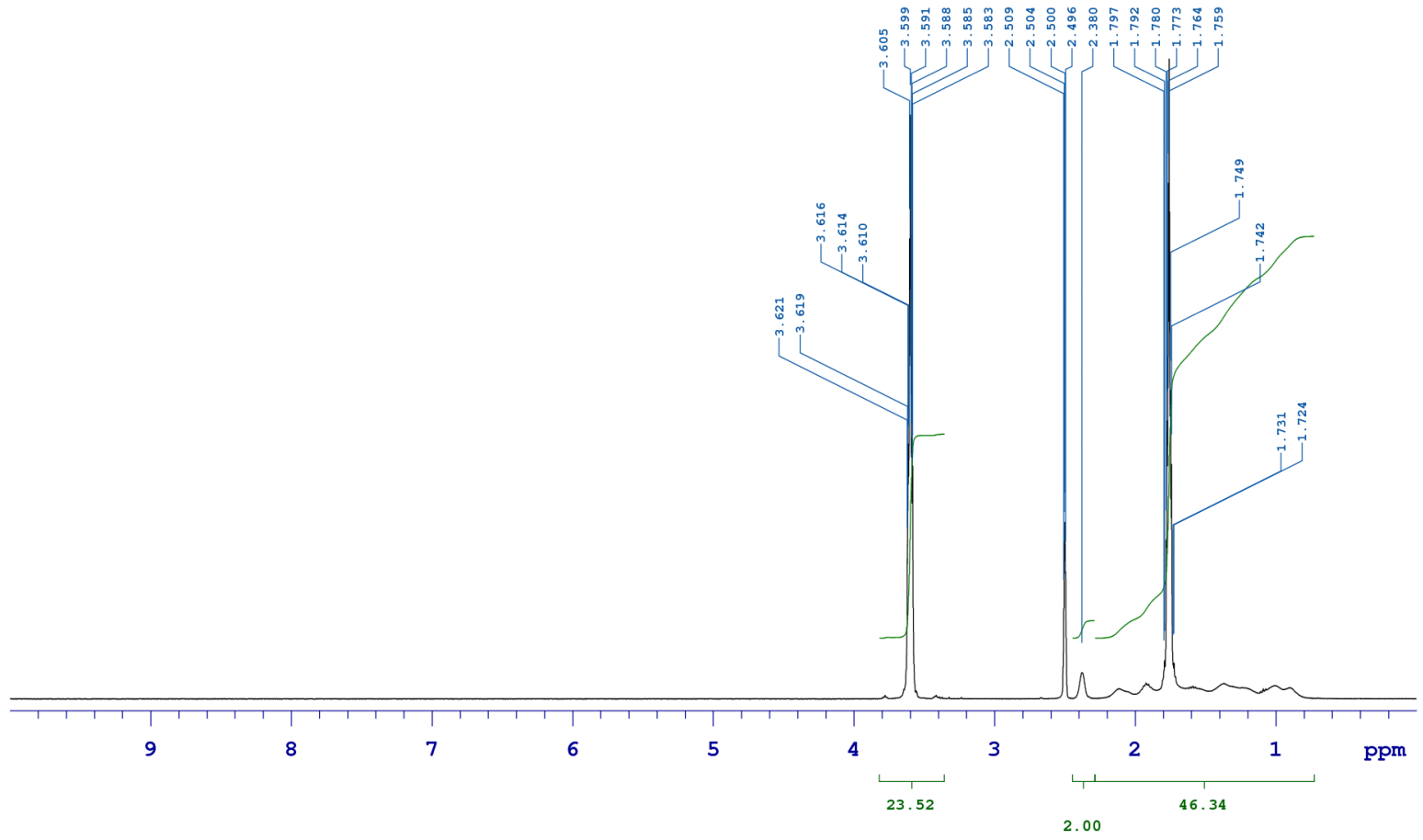

Figure S6. ${ }^{1} \mathrm{H}$ NMR $\left(399.54 \mathrm{MHz}, \mathrm{DMSO}-\mathrm{d}_{6}\right)$ of $\left[\mathrm{Mg}(\mathrm{THF})_{6}\right]\left(\mathrm{CB}_{11} \mathrm{H}_{12}\right)_{2}(3)$. 


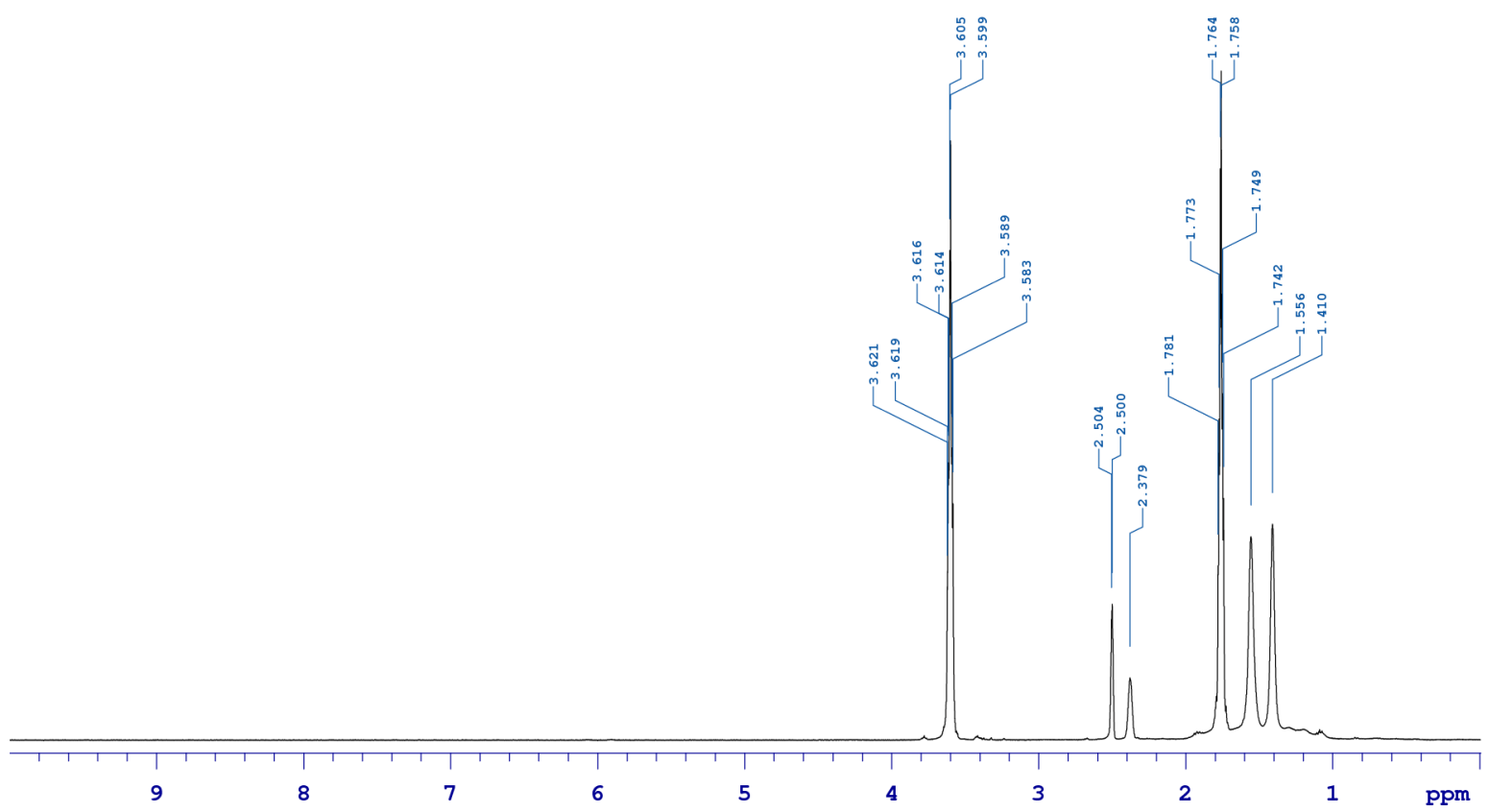

Figure S7. ${ }^{1} \mathrm{H}\left\{{ }^{11} \mathrm{~B}\right\}$ NMR $\left(399.54 \mathrm{MHz}\right.$, DMSO-d $\left.{ }_{6}\right)$ of $\left[\mathrm{Mg}(\mathrm{THF})_{6}\right]\left(\mathrm{CB}_{11} \mathrm{H}_{12}\right)_{2}(3)$.

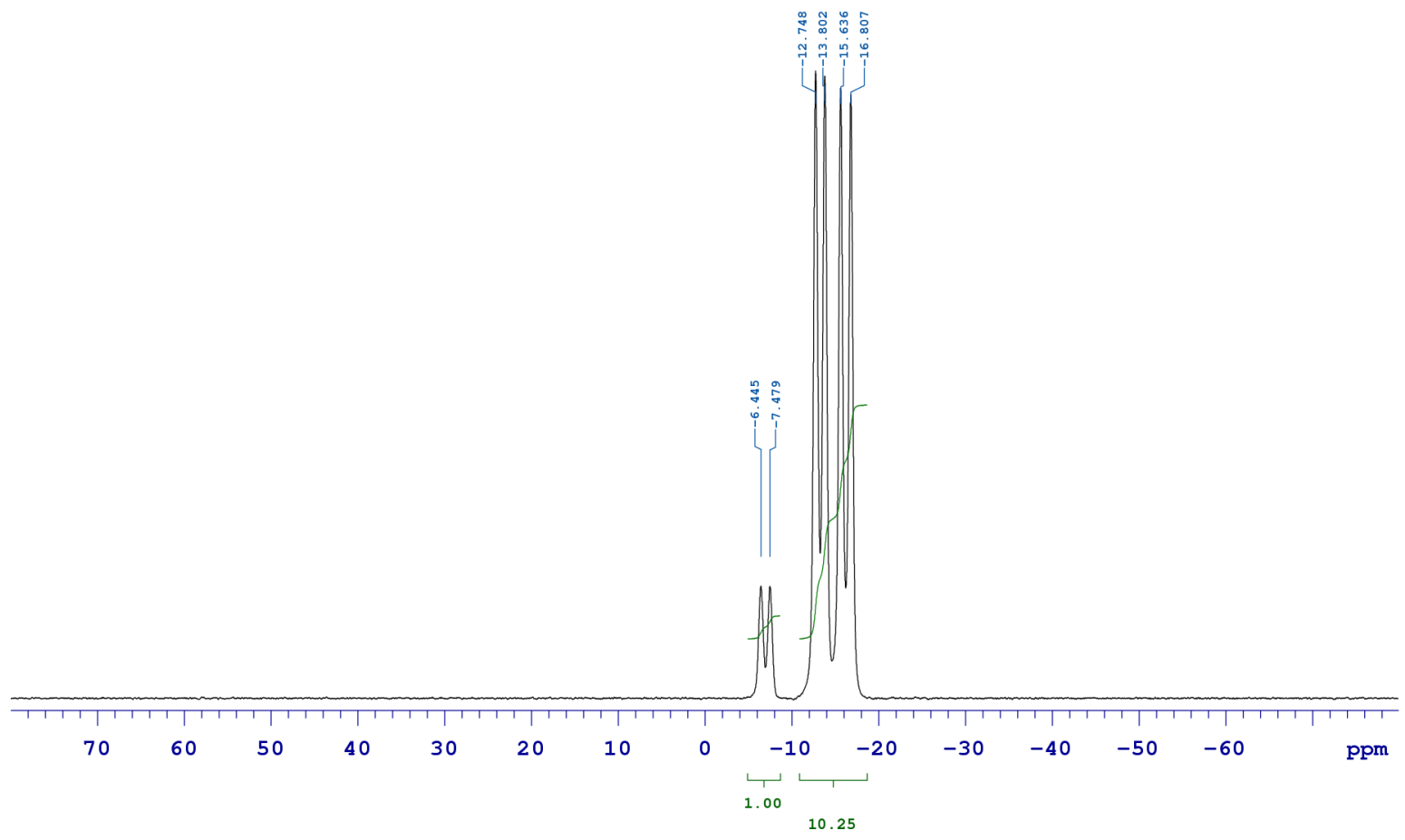

Figure S8. ${ }^{11}$ B NMR $\left(128.19 \mathrm{MHz}, \mathrm{DMSO}-\mathrm{d}_{6}\right)$ of $\left[\mathrm{Mg}(\mathrm{THF})_{6}\right]\left(\mathrm{CB}_{11} \mathrm{H}_{12}\right)_{2}(3)$. 


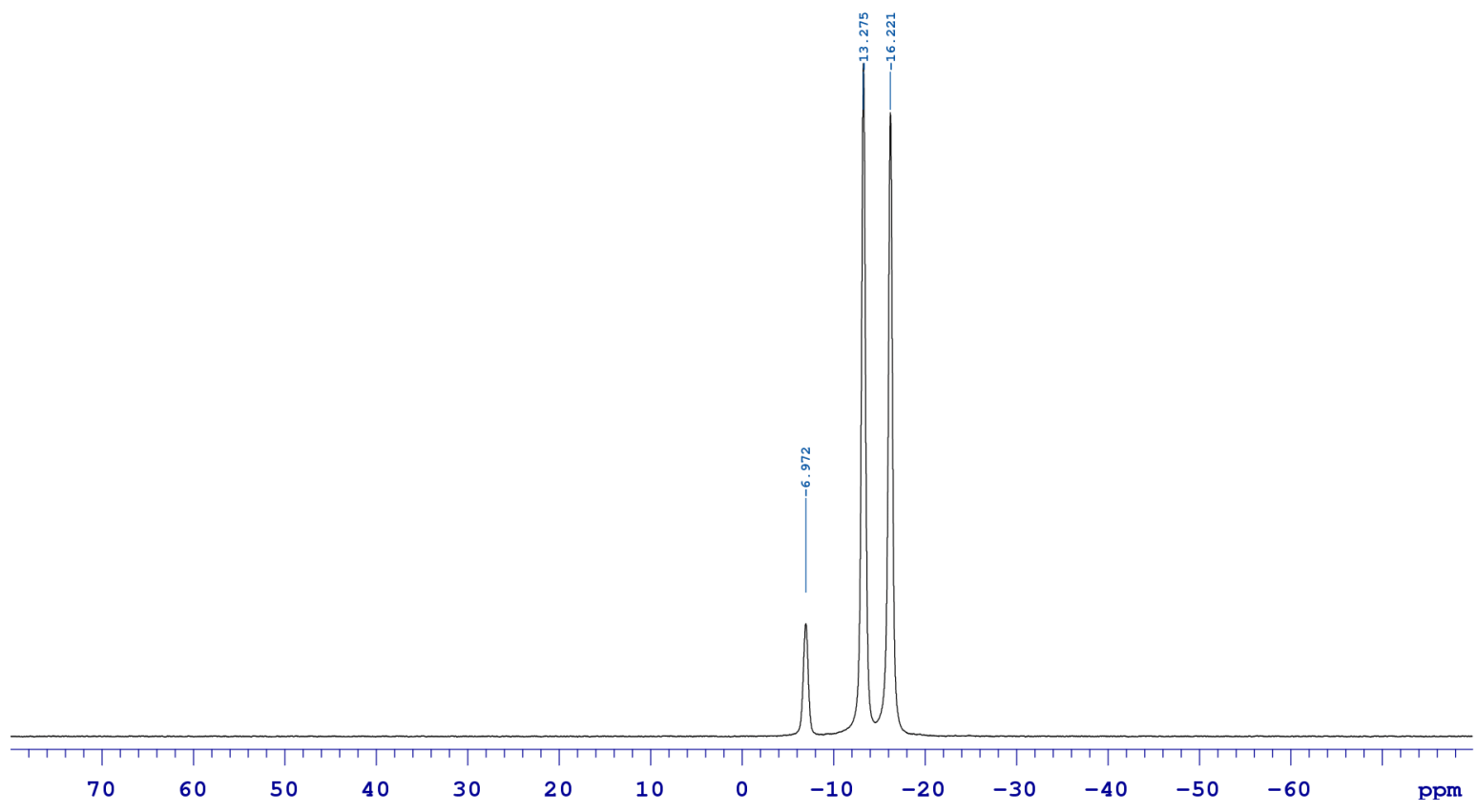

Figure S9. ${ }^{11} \mathrm{~B}\left\{{ }^{1} \mathrm{H}\right\}$ NMR $\left(128.19 \mathrm{MHz}\right.$, DMSO-d $\left.{ }_{6}\right)$ of $\left[\mathrm{Mg}(\mathrm{THF})_{6}\right]\left(\mathrm{CB}_{11} \mathrm{H}_{12}\right)_{2}(\mathbf{3})$.

Agilent Technologies
Sample Name

Date collected 2014-11-07

Pulse sequence CARBON
Solvent dmso

Temperature 25

Study owner toyota

Printed from dy.chem.lsa.umich.edu-vnmrs500

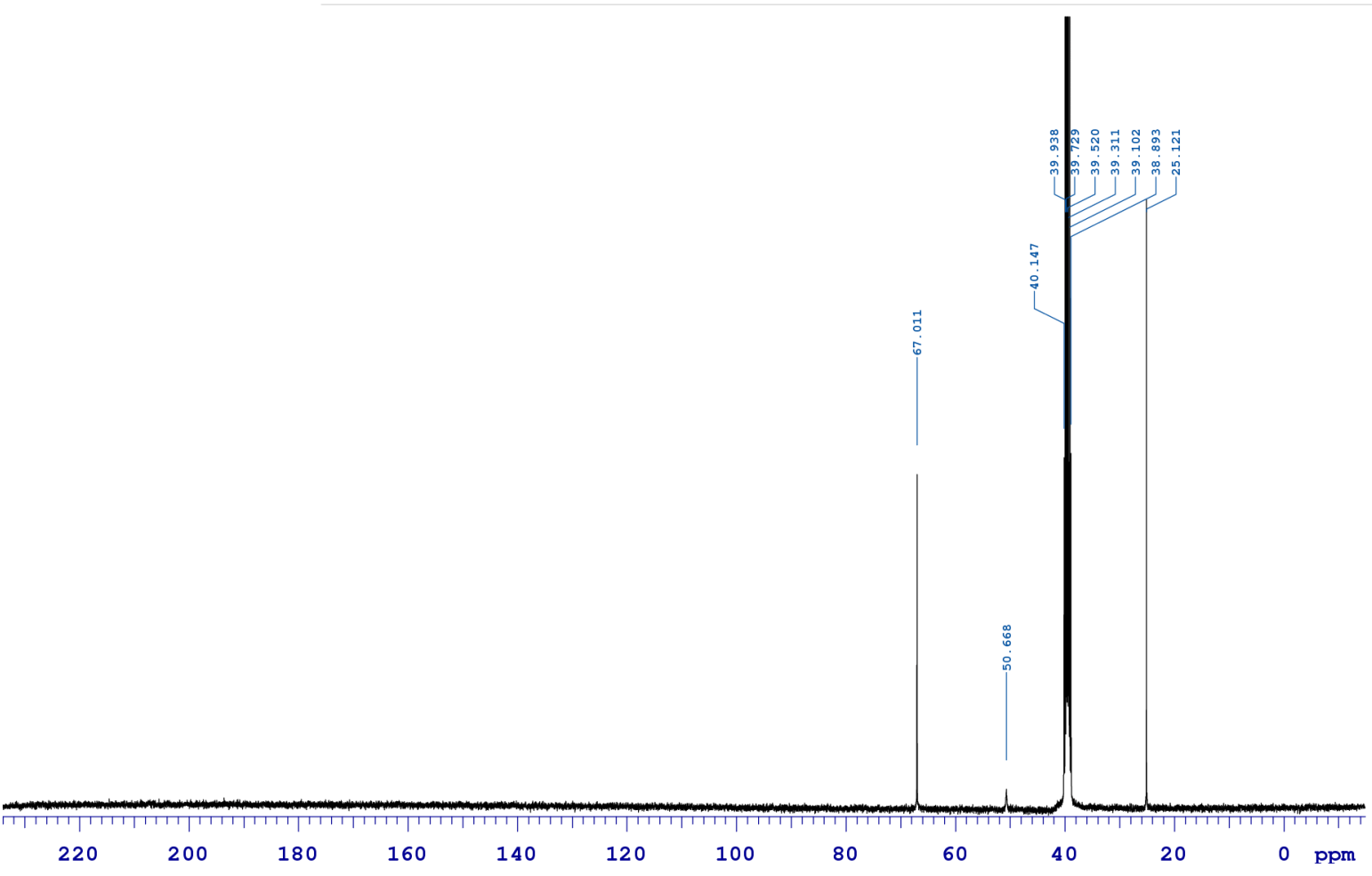

Figure S10. ${ }^{13} \mathrm{C}$ NMR (100.47 MHz, DMSO-d 6 of $\left[\mathrm{Mg}(\mathrm{THF})_{6}\right]\left(\mathrm{CB}_{11} \mathrm{H}_{12}\right)_{2}(\mathbf{3})$. 


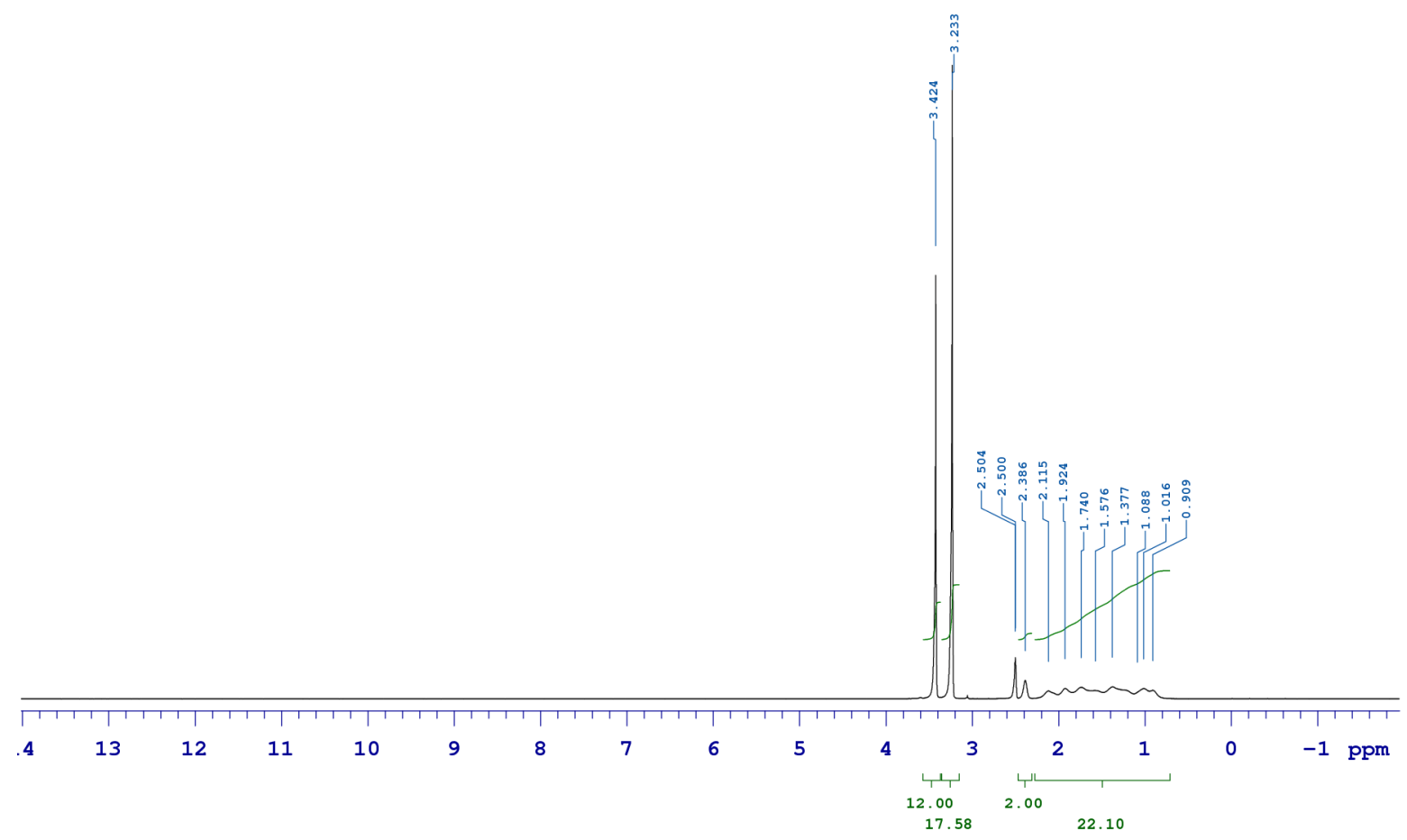

Figure S11. ${ }^{1} \mathrm{H}$ NMR $\left(399.54 \mathrm{MHz}, \mathrm{DMSO}-\mathrm{d}_{6}\right)$ of $\left[\mathrm{Mg}(\mathrm{DME})_{3}\right]\left(\mathrm{CB}_{11} \mathrm{H}_{12}\right)_{2}(\mathbf{4})$.

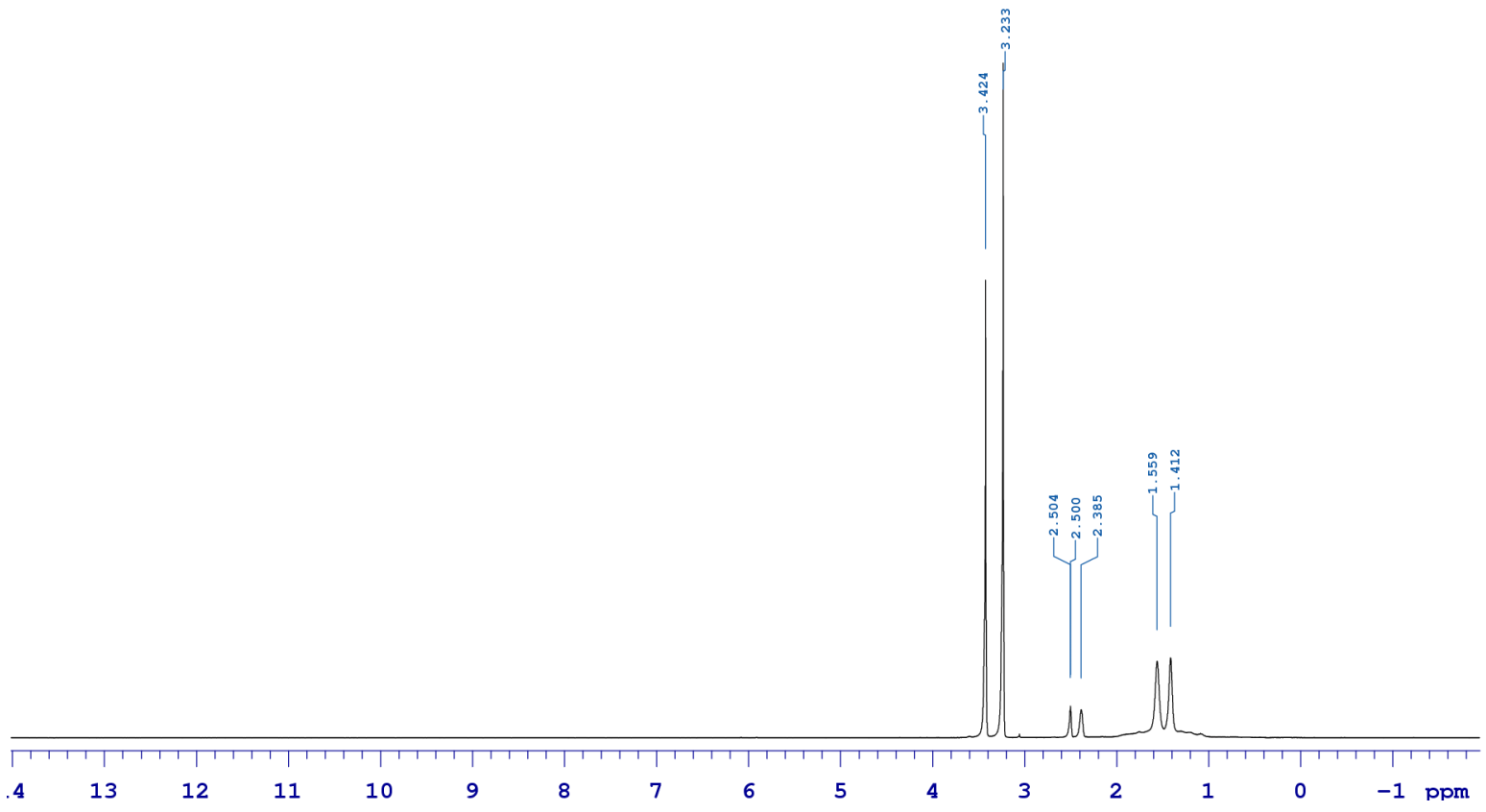

Figure S12. ${ }^{1} \mathrm{H}\left\{{ }^{11} \mathrm{~B}\right\}$ NMR $\left(399.54 \mathrm{MHz}, \mathrm{DMSO}-\mathrm{d}_{6}\right)$ of $\left[\mathrm{Mg}(\mathrm{DME})_{3}\right]\left(\mathrm{CB}_{11} \mathrm{H}_{12}\right)_{2}(\mathbf{4})$. 


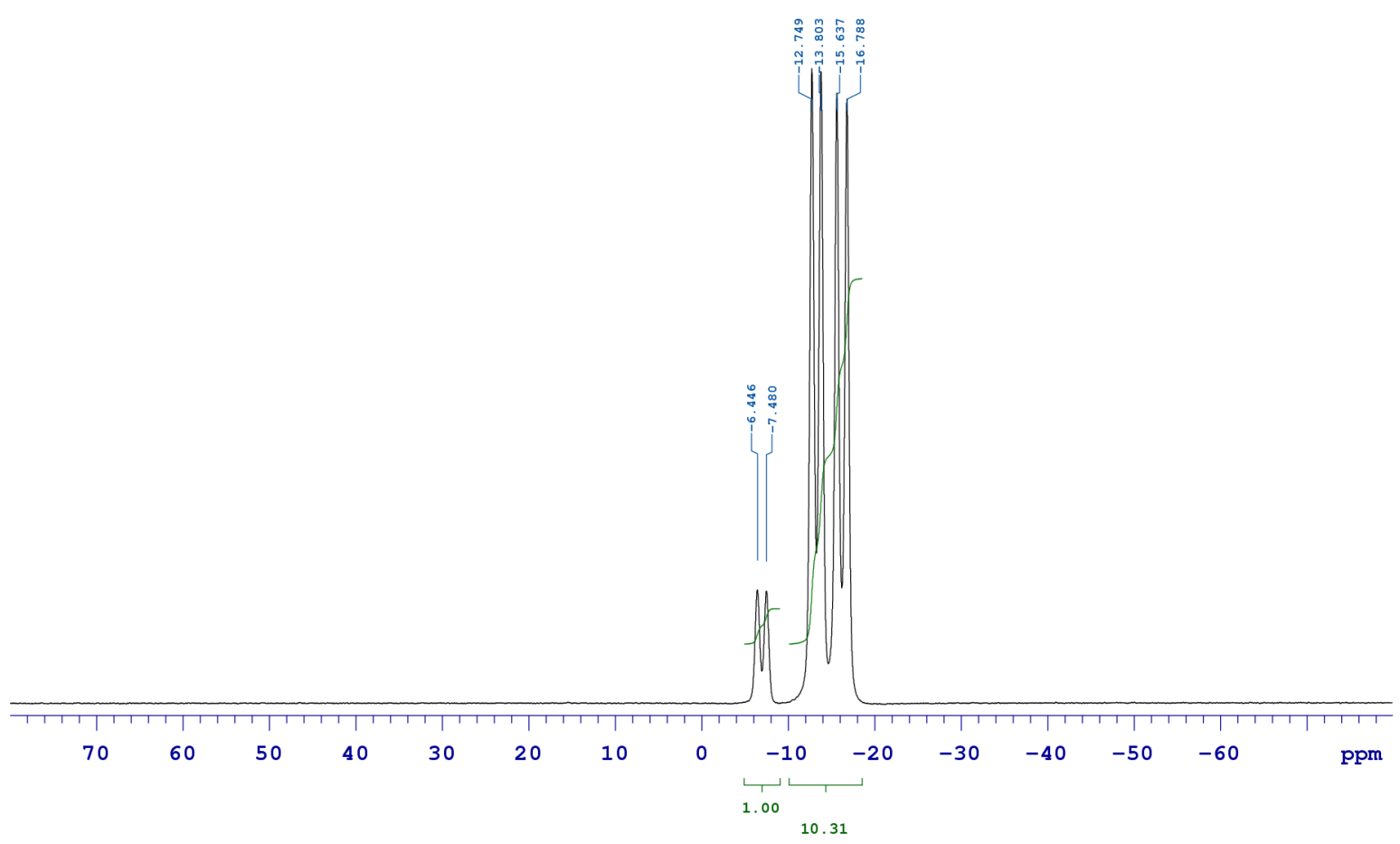

Figure S13. ${ }^{11}$ B NMR (128.19 MHz, DMSO-d $\left.\mathrm{d}_{6}\right)$ of $\left[\mathrm{Mg}(\mathrm{DME})_{3}\right]\left(\mathrm{CB}_{11} \mathrm{H}_{12}\right)_{2}(\mathbf{4})$.

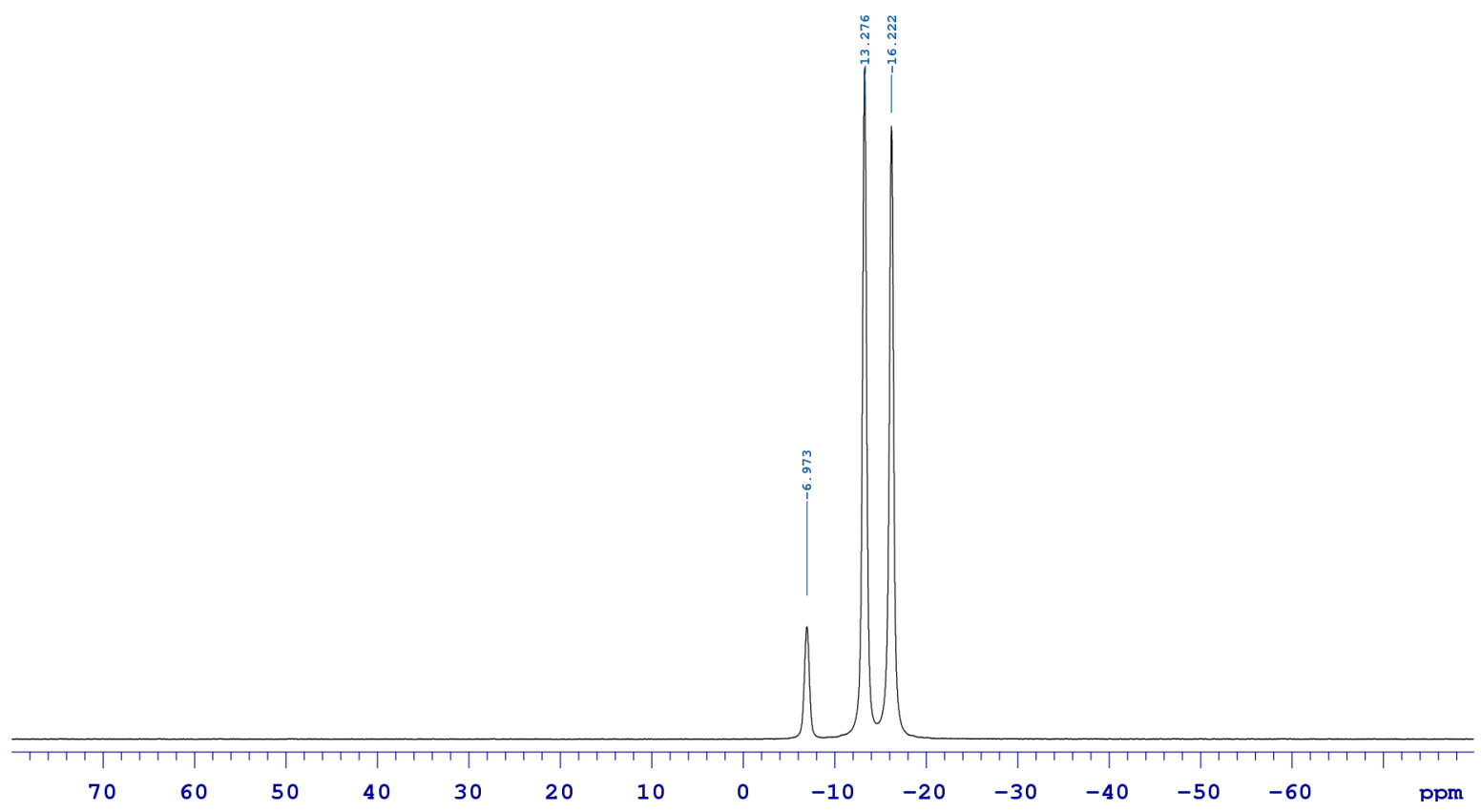

Figure S14. ${ }^{11} \mathrm{~B}\left\{{ }^{1} \mathrm{H}\right\}$ NMR (128.19 MHz, DMSO-d 6 of $\left[\mathrm{Mg}(\mathrm{DME})_{3}\right]\left(\mathrm{CB}_{11} \mathrm{H}_{12}\right)_{2}$ (4). 


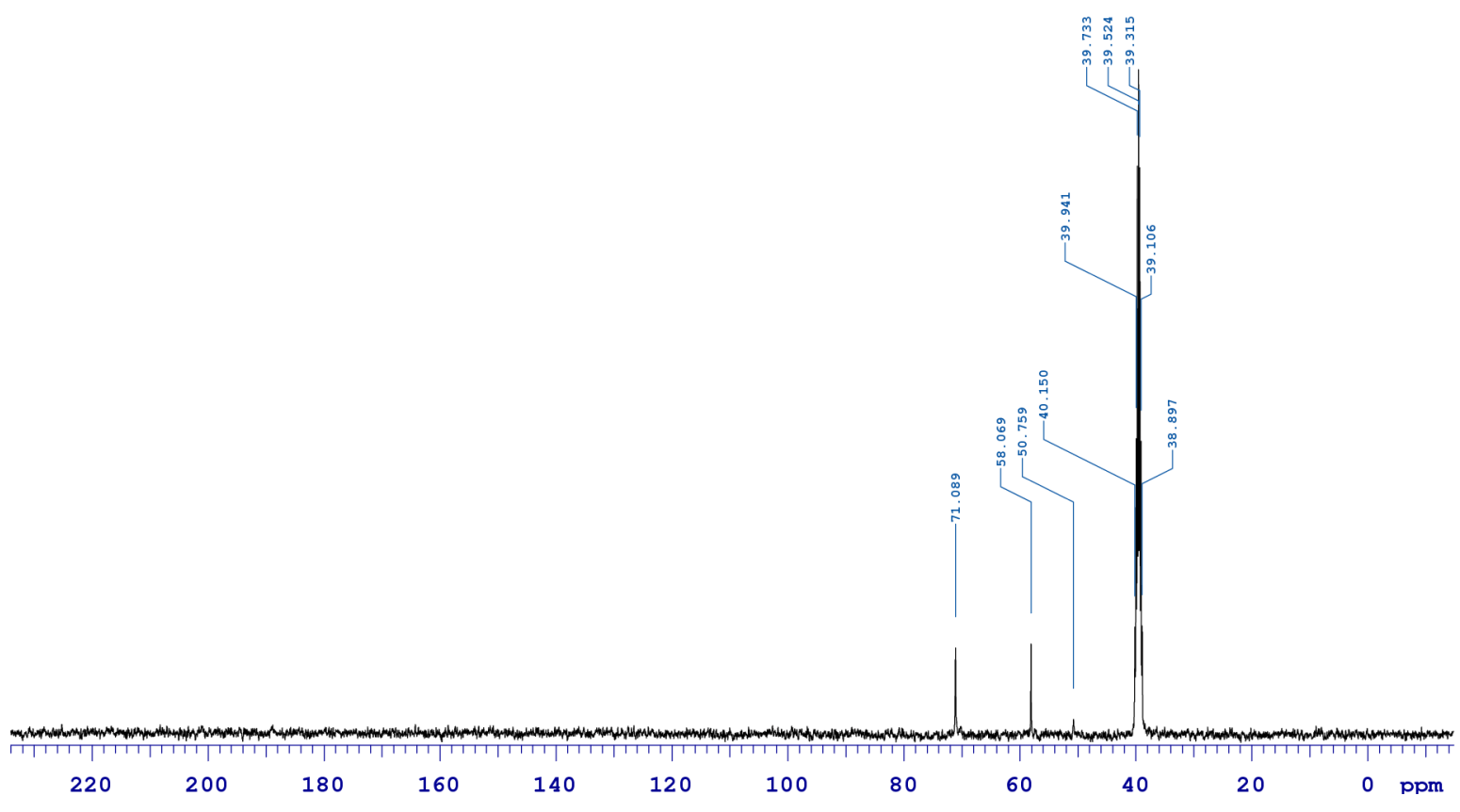

Figure S15. ${ }^{13} \mathrm{C}$ NMR $\left(100.47 \mathrm{MHz}\right.$, DMSO-d $\left.\mathrm{d}_{6}\right)$ of $\left[\mathrm{Mg}(\mathrm{DME})_{3}\right]\left(\mathrm{CB}_{11} \mathrm{H}_{12}\right)_{2}(\mathbf{4})$.

Agilent Technologies

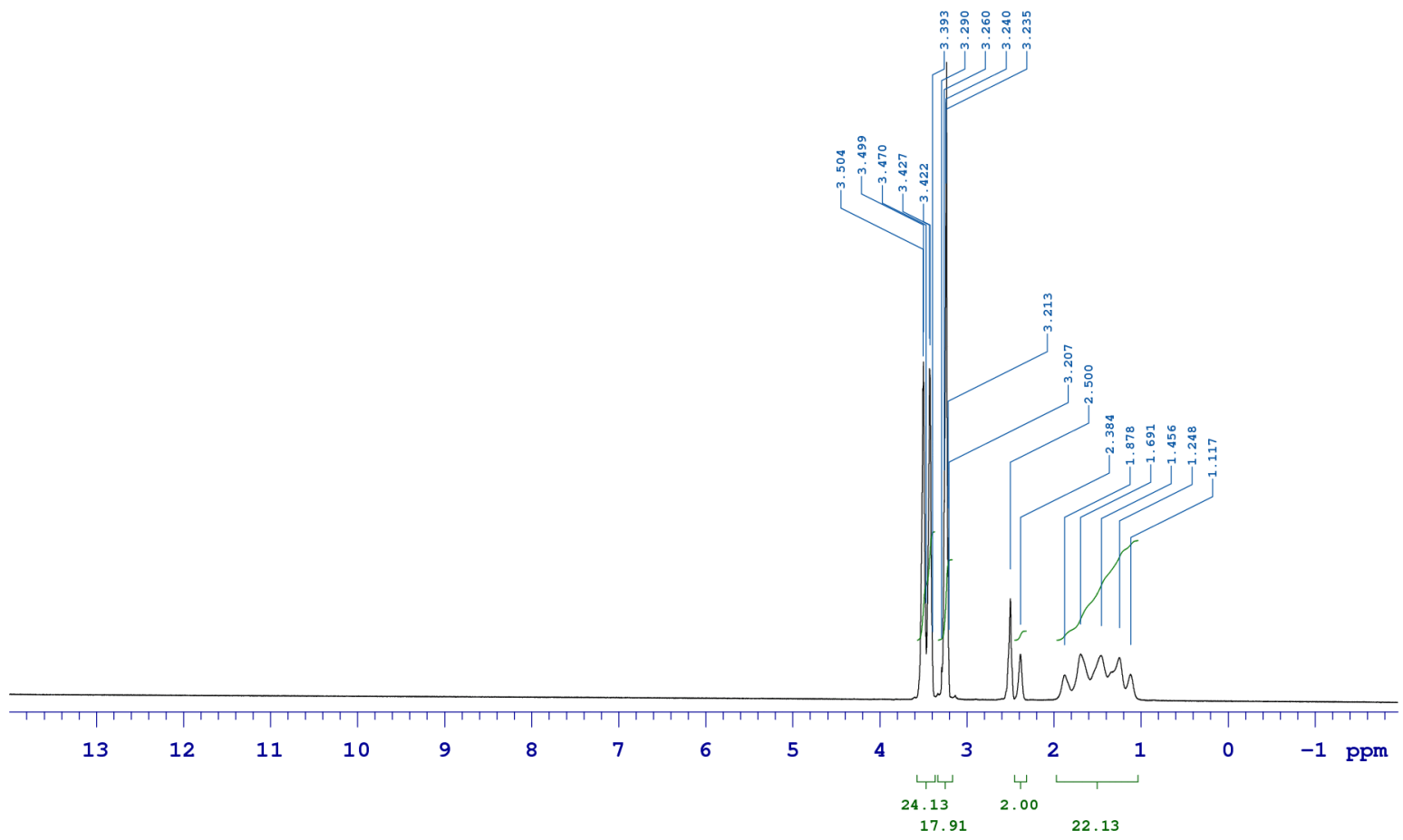

Figure S16. ${ }^{1} \mathrm{H}$ NMR $\left(699.76 \mathrm{MHz}, \mathrm{DMSO}-\mathrm{d}_{6}\right)$ of $\left[\mathrm{Mg}(\mathrm{G} 2)_{2}\right]\left(\mathrm{CB}_{11} \mathrm{H}_{12}\right)_{2} \cdot \mathrm{G} 2(\mathbf{5})$. 


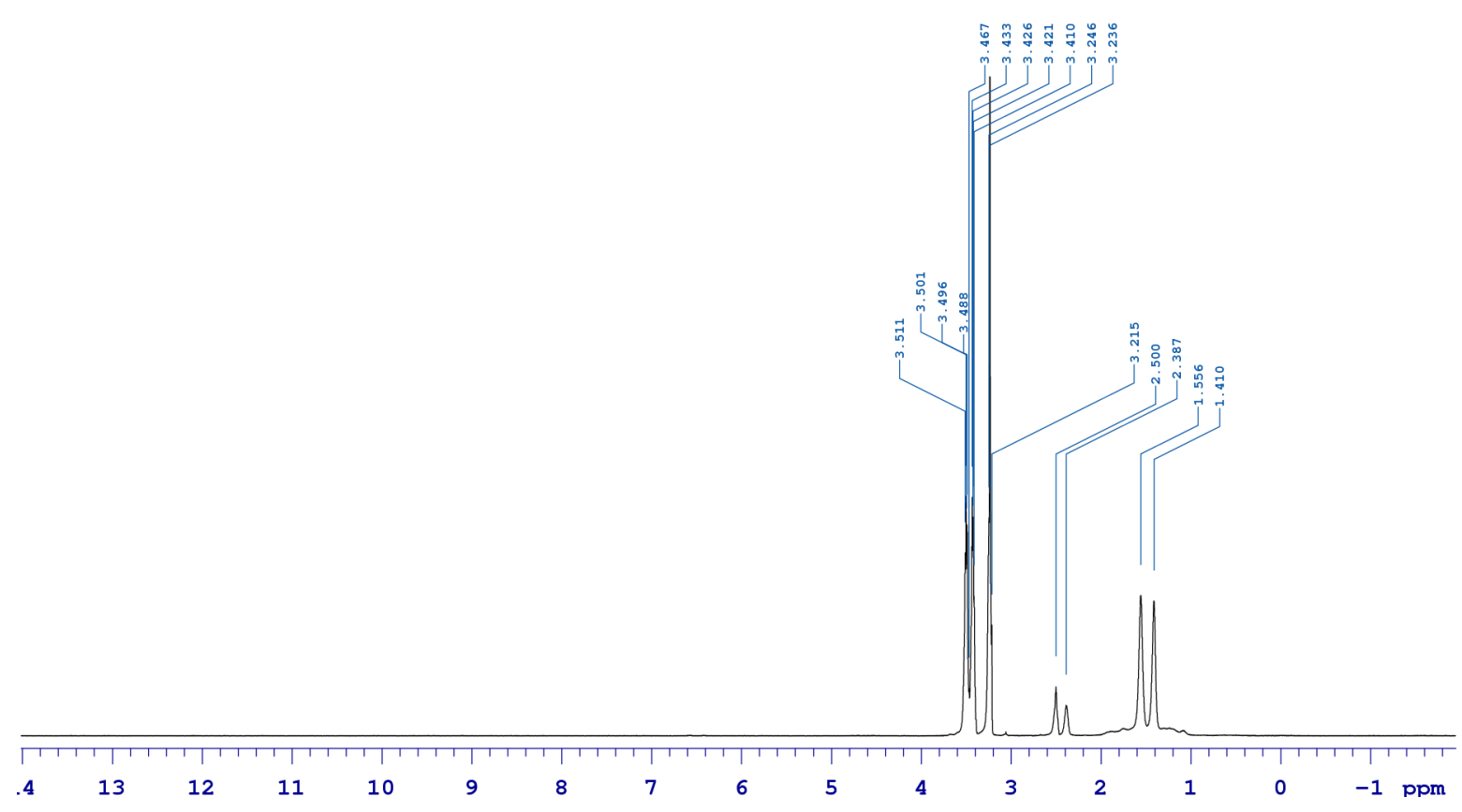

Figure S17. ${ }^{1} \mathrm{H}\left\{{ }^{11} \mathrm{~B}\right\}$ NMR $\left(399.54 \mathrm{MHz}\right.$, DMSO-d $\left.\mathrm{d}_{6}\right)$ of $\left[\mathrm{Mg}(\mathrm{G} 2)_{2}\right]\left(\mathrm{CB}_{11} \mathrm{H}_{12}\right)_{2} \cdot \mathrm{G} 2(\mathbf{5})$.

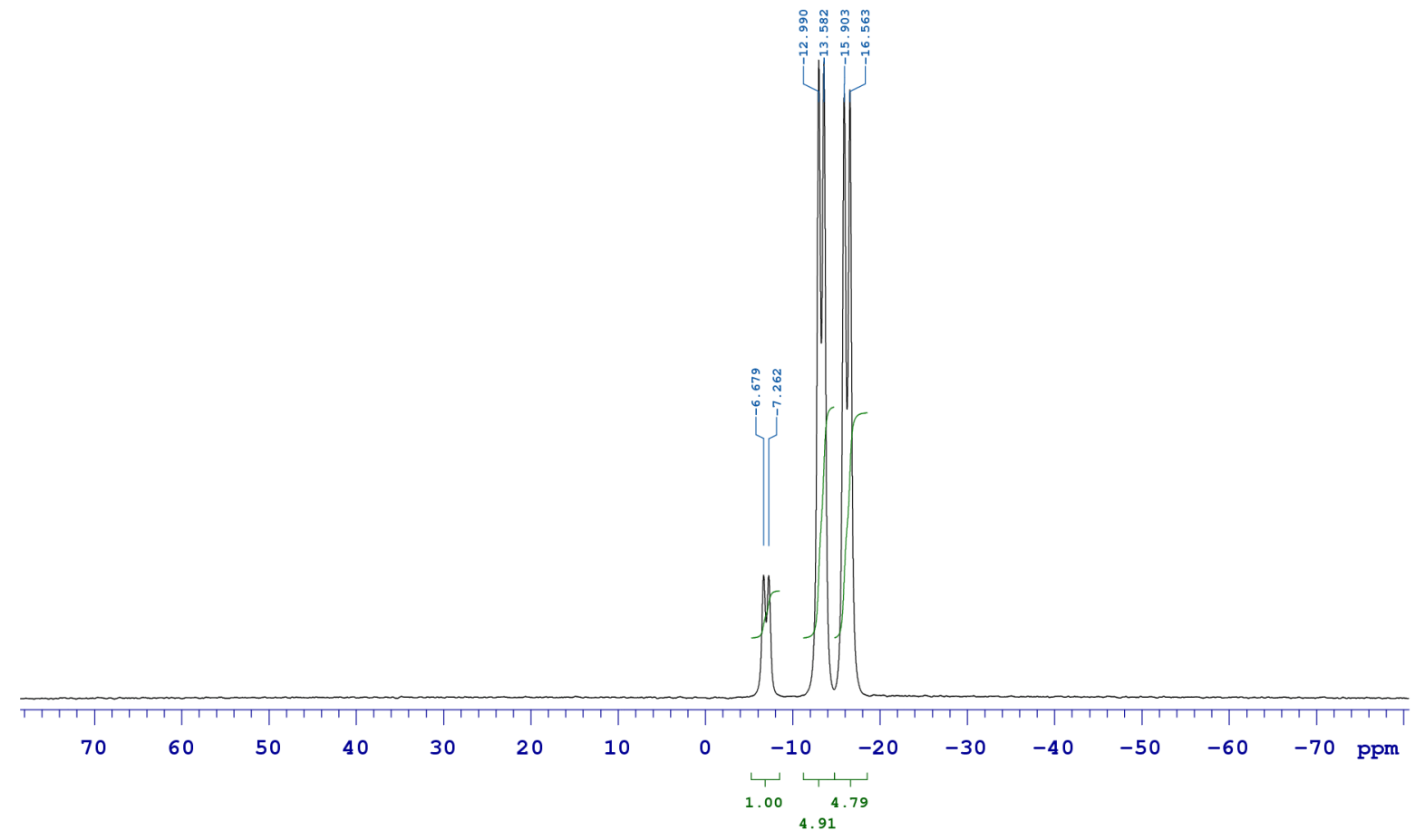

Figure S18. ${ }^{11} \mathrm{~B}$ NMR $\left(224.51 \mathrm{MHz}, \mathrm{DMSO}-\mathrm{d}_{6}\right)$ of $\left[\mathrm{Mg}(\mathrm{G} 2)_{2}\right]\left(\mathrm{CB}_{11} \mathrm{H}_{12}\right)_{2} \cdot \mathrm{G} 2(\mathbf{5})$. 


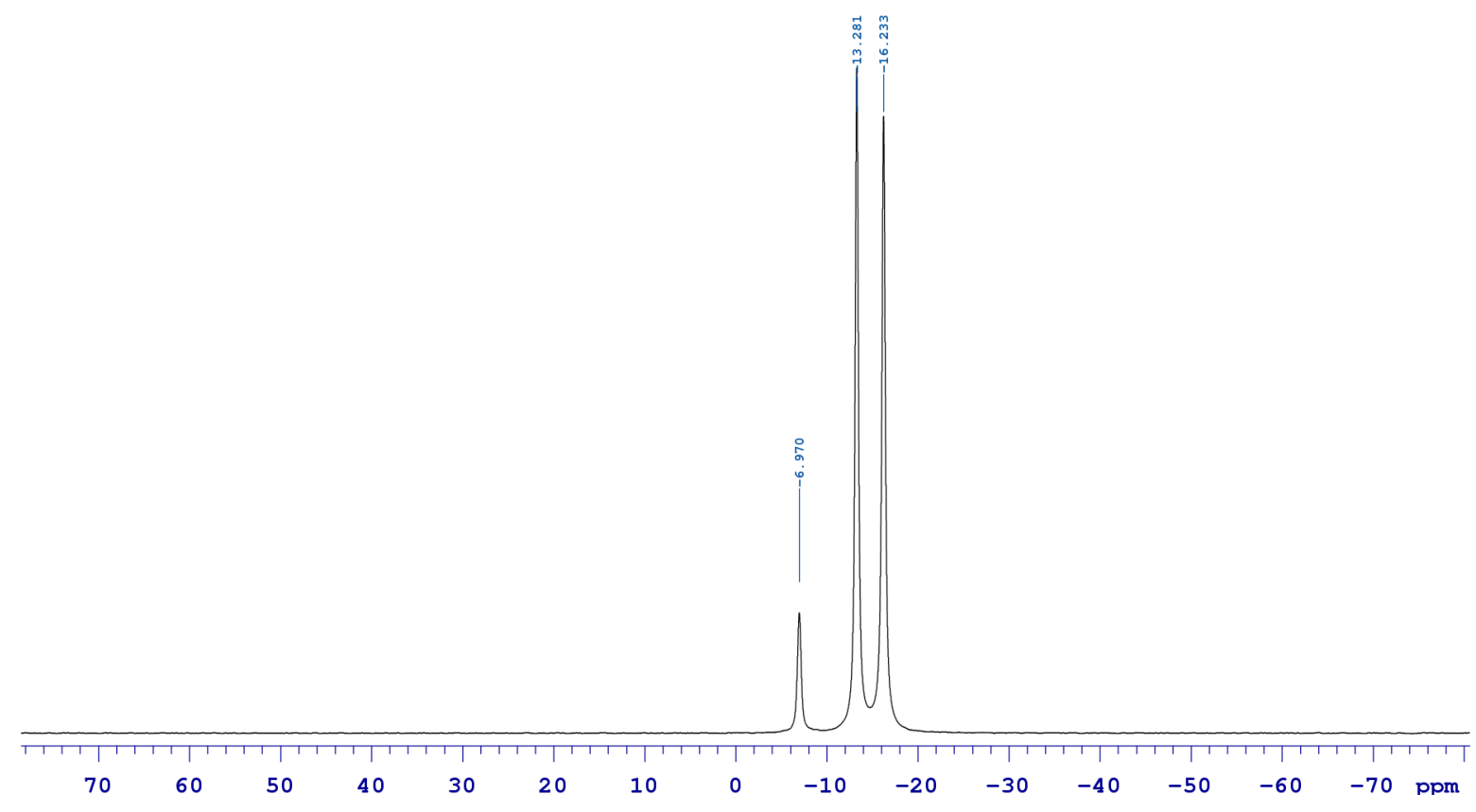

Figure S19. ${ }^{11} \mathrm{~B}\left\{{ }^{1} \mathrm{H}\right\}$ NMR $\left(224.51 \mathrm{MHz}\right.$, DMSO-d 6 of $\left[\mathrm{Mg}(\mathrm{G} 2)_{2}\right]\left(\mathrm{CB}_{11} \mathrm{H}_{12}\right)_{2} \cdot \mathrm{G} 2(\mathbf{5})$.

Agilent Technologies

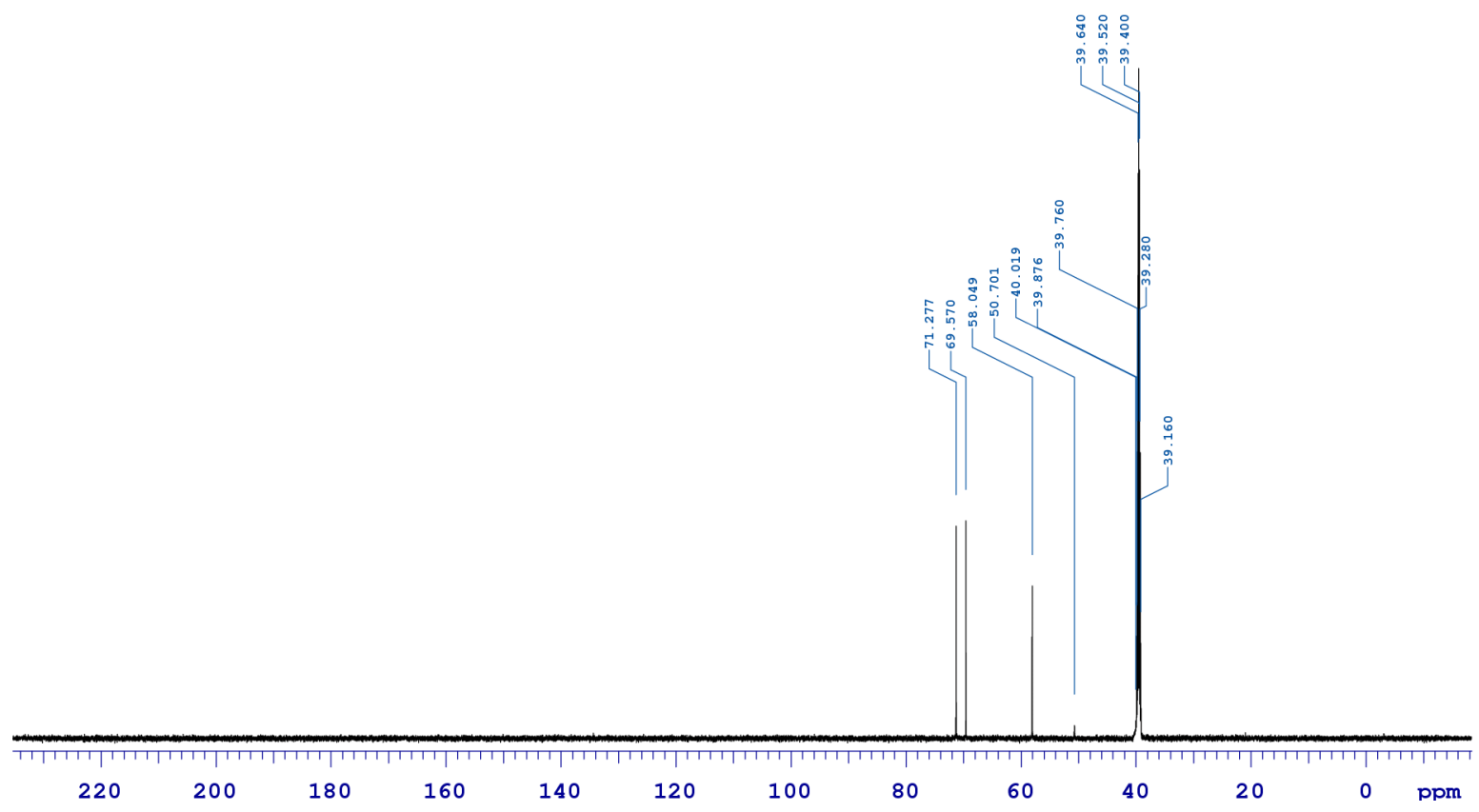

Figure S20. ${ }^{13} \mathrm{C}$ NMR $\left(175.97 \mathrm{MHz}, \mathrm{DMSO}-\mathrm{d}_{6}\right)$ of $\left[\mathrm{Mg}(\mathrm{G} 2)_{2}\right]\left(\mathrm{CB}_{11} \mathrm{H}_{12}\right)_{2} \cdot \mathrm{G} 2(\mathbf{5})$. 


\section{X-Ray Crystallographic Data}

X-ray quality crystals of $\mathbf{2} \cdot 1.5\left(\mathrm{H}_{2} \mathrm{O}\right)$ were obtained by slow cooling of a $45^{\circ} \mathrm{C}$ saturated solution; for $\mathbf{4}$, were obtained directly from synthetic procedure; for $\mathbf{5}$, by slowly evaporating THF from the filtrate obtained upon extracting solid mixture 3: $\mathrm{AgBr}(1: 2)(812 \mathrm{mg})$ with $5 \mathrm{~mL}$ of diglyme; for $\left[\mathrm{Mg}(\mathrm{G} 4)_{2}\left(\mathrm{H}_{2} \mathrm{O}\right)\right]\left(\mathrm{CB}_{11} \mathrm{H}_{12}\right)_{2}(\mathbf{6})$, by layering anhydrous $\mathrm{Et}_{2} \mathrm{O}$ onto a $1 \mathrm{M} \mathrm{MMC/G} 4$ solution for $16 \mathrm{~h}$, then removing the upper ethereal layer, followed

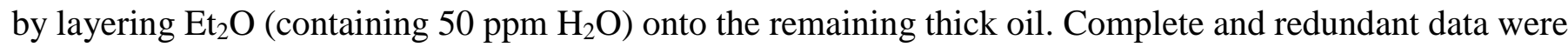
collected on a single flash-cooled crystal $(\mathrm{T}=85(2) \mathrm{K}$ with an Oxford Cryostream LT device) using a Rigaku AFC10K Saturn 944+ CCD-based X-ray diffractometer equipped with the Micromax-007HF Cu-target microfocus rotating anode $(\lambda=1.54178 \AA$ ) operated at $1.2 \mathrm{~kW}$ power $(40 \mathrm{kV}, 30 \mathrm{~mA})$. The X-ray intensities were measured with the detector placed at a distance $42 \mathrm{~mm}$ from the crystal. Absorption corrections were applied

using the SADABS empirical method. ${ }^{[5]}$ The structures were solved and refined using the Bruker SHELXTL ${ }^{[6]}$ software package. All of the non-hydrogen atoms were refined with anisotropic thermal parameters. In 4, 5, and $\mathbf{6}$, the refinement of $\mathrm{H}$-atoms was mixed. Hydrogen atoms were located in difference Fourier maps and refined individually for: $i$ ) all atoms, with $\mathrm{O}-\mathrm{H}$ bond distances in water molecules restrained to $0.84 \AA$ using DFIX, in $\mathbf{2} \cdot 1.5\left(\mathrm{H}_{2} \mathrm{O}\right)$; $i$ i) all atoms, except partially occupied $\mathrm{B}$ - and $\mathrm{C}$-atoms of carboranes in $\mathbf{4}$; iii) all B- and C-atoms of carborane molecules in 5; $i v$ ) $\mathrm{C}$-atoms of carboranes and of water molecules in $\mathbf{6}$. The remaining $\mathrm{H}$-atoms were included at geometrically idealized positions. In $2 \cdot 1.5\left(\mathrm{H}_{2} \mathrm{O}\right)$, one of the co-crystallized water molecules displayed symmetry-induced disorder which was modeled using PART -1 instruction; since the $\mathrm{H}$-atom of this water refined with an extreme anisotropic ellipsoid, it was manually fixed at 0.05 . In 4, two carborane half-cages displayed symmetry induced disorder for C- and B-atoms, which was modeled by allowing shared 50:50 occupancy for B and C occupying the same position. In 5, an inversion twin was refined with the 65:35 ratio. In 6, one of the side chains of tetraglyme displayed a minor disorder, which was refined with the 60:40 ratio between two orientations. The crystallographic data and the details of data collection and structure refinement are provided in Table S1. Figures were prepared using molecular graphics in X-SEED. ${ }^{[7]}$ CIF files have been deposited with the Cambridge Crystallographic Data Centre, CCDC Nos. $1039287\left(\mathbf{2} \cdot 1.5\left(\mathrm{H}_{2} \mathrm{O}\right)\right), 1038588$ (4), 1038587 (5), and 1038586 (6). Copies of this information may be obtained free of charge from The Cambridge Crystallographic Data Centre via www.ccdc.cam.ac.uk/data_request/cif or from The Director, CCDC, 12 Union Road, Cambridge CB2 1EZ, UK [fax:(int. code) +44 (1223) 336-033 or e-mail:deposit@ccdc.cam.ac.uk]. 
Table S1. Crystallographic details for $\mathbf{2} \cdot 1.5\left(\mathrm{H}_{2} \mathrm{O}\right), \mathbf{4}, \mathbf{5}$, and $\mathbf{6}$.

\begin{tabular}{|c|c|c|c|c|}
\hline & $2 \cdot 1.5\left(\mathrm{H}_{2} \mathrm{O}\right)$ & 4 & 5 & 6 \\
\hline Formula & $\mathrm{C}_{2} \mathrm{H}_{39} \mathrm{~B}_{22} \mathrm{MgO}_{7.50}$ & $\mathrm{C}_{14} \mathrm{H}_{54} \mathrm{~B}_{22} \mathrm{MgO}_{6}$ & $\mathrm{C}_{20} \mathrm{H}_{66} \mathrm{~B}_{22} \mathrm{MgO}_{9}$ & $\mathrm{C}_{22} \mathrm{H}_{70} \mathrm{~B}_{22} \mathrm{MgO}_{11}$ \\
\hline $\mathrm{FW}, \mathrm{g} \cdot \mathrm{mol}^{-1}$ & 445.46 & 580.70 & 712.85 & 772.91 \\
\hline Color, habit & colorless needle & colorless plate & colorless plate & colorless needle \\
\hline Crystal dimensions $\left(\mathrm{mm}^{3}\right)$ & $0.22 \times 0.17 \times 0.17$ & $0.10 \times 0.06 \times 0.01$ & $0.24 \times 0.24 \times 0.09$ & $0.24 \times 0.06 \times 0.06$ \\
\hline Crystal system & triclinic & triclinic & monoclinic & monoclinic \\
\hline Space group & $P 1$ & $P 1$ & $C c$ & $C c$ \\
\hline$a, \AA$ & $10.2650(4)$ & $10.9344(2)$ & $23.4092(16)$ & $14.2944(3)$ \\
\hline$b, \AA$ & $11.9726(2)$ & $11.9271(2)$ & $8.8170(2)$ & $62.906(5)$ \\
\hline$c, \AA$ & $12.3503(5)$ & $14.6311(10)$ & 23.7953(17) & $14.9555(3)$ \\
\hline$\alpha, \operatorname{deg}$ & $64.124(6)$ & $91.442(6)$ & & \\
\hline$\beta, \operatorname{deg}$ & $65.480(4)$ & $92.196(7)$ & $124.688(9)$ & $91.398(5)$ \\
\hline$\gamma, \operatorname{deg}$ & $78.322(5)$ & $114.536(8)$ & & \\
\hline$V, \AA^{3}$ & $1242.08(10)$ & $1732.78(16)$ & $4038.4(5)$ & $13444.0(11)$ \\
\hline Z & 2 & 2 & 4 & 12 \\
\hline$d_{\text {calcd }}, \mathrm{g} \cdot \mathrm{cm}^{-3}$ & 1.191 & 1.113 & 1.172 & 1.146 \\
\hline$\mu, \mathrm{mm}^{-1}$ & 0.806 & 0.651 & 0.703 & 0.704 \\
\hline$\theta$ range, deg & $4.11-68.22$ & $3.03-68.24$ & $2.26-68.24$ & $2.81-68.26$ \\
\hline Unique data & 33328 & 46654 & 56663 & 188980 \\
\hline obs data, $I>2 \sigma(I)$ & 4249 & 4904 & 7162 & 19514 \\
\hline Parameters & 448 & 596 & 566 & 1564 \\
\hline $\mathrm{GOF}^{\mathrm{a}}$ on $F^{2}$ & 1.065 & 1.141 & 1.229 & 1.116 \\
\hline$R 1^{b}, w R 2^{c}[I>2 \sigma(I)]$ & $0.0347,0.1010$ & $0.0794,0.2222$ & $0.0350,0.0883$ & $0.0649,0.1670$ \\
\hline$R 1^{b}, w R 2^{c}$ (all data) & $0.0358,0.1021$ & $0.0915,0.2382$ & $0.0350,0.0883$ & $0.0783,0.1811$ \\
\hline$\Delta \rho_{\max , \min }\left(\mathrm{e} \cdot \mathrm{A}^{-3}\right)$ & $0.298,-0.394$ & $0.440,-0.638$ & $0.304,-0.613$ & $0.475,-0.573$ \\
\hline$T_{\min } / T_{\max }$ & $0.78 / 0.88$ & $0.67 / 0.99$ & $0.78 / 0.95$ & $0.70 / 1.00$ \\
\hline
\end{tabular}

${ }^{a} \mathrm{GOF}=\left[\Sigma\left[w\left(F_{o}^{2}-F_{c}^{2}\right)^{2}\right] /\left(\mathrm{N}_{\mathrm{obs}}-\mathrm{N}_{\text {params }}\right)\right]^{1 / 2}$.

${ }^{b} R 1=\Sigma|| F_{o}|-| F_{c}|| / \Sigma\left|F_{o}\right| \cdot{ }^{c} w R 2=\left[\Sigma\left[w\left(F_{o}{ }^{2}-F_{c}{ }^{2}\right)^{2}\right] / \Sigma\left[w\left(F_{o}{ }^{2}\right)^{2}\right]\right]^{1 / 2}$. 


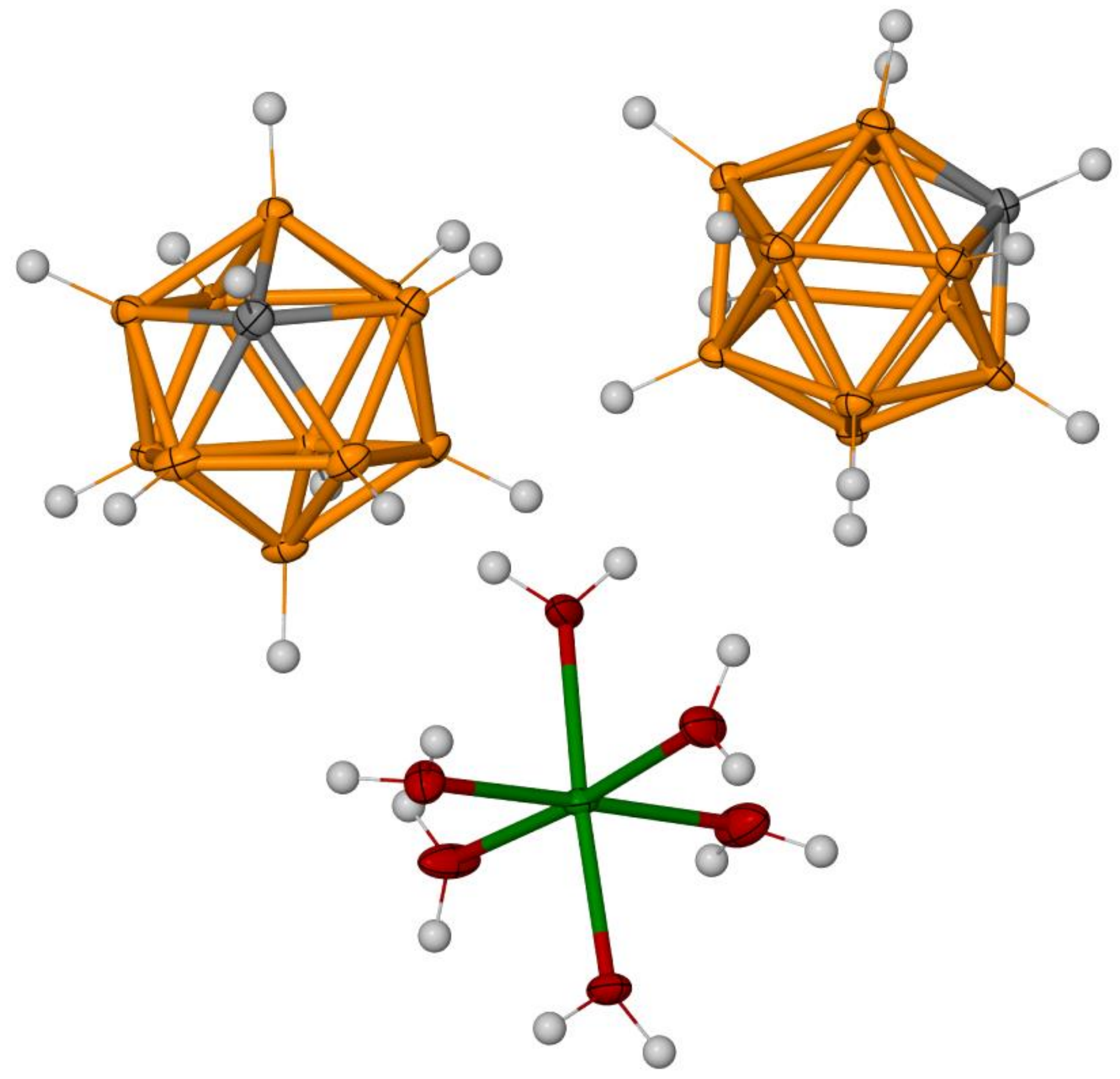

Figure S21. Thermal ellipsoid plot of asymmetric unit of $\left[\mathrm{Mg}\left(\mathrm{H}_{2} \mathrm{O}\right)_{6}\right]\left(\mathrm{CB}_{11} \mathrm{H}_{12}\right)_{2} \cdot 1.5 \mathrm{H}_{2} \mathrm{O}\left(2 \cdot 1.5\left(\mathrm{H}_{2} \mathrm{O}\right)\right)$, shown at $50 \%$ probability level. Co-crystallized water molecules are omitted for clarity. Element colors: $\mathrm{Mg}(\mathrm{green}), \mathrm{O}$ (red), B (orange), C (grey), H (white). 


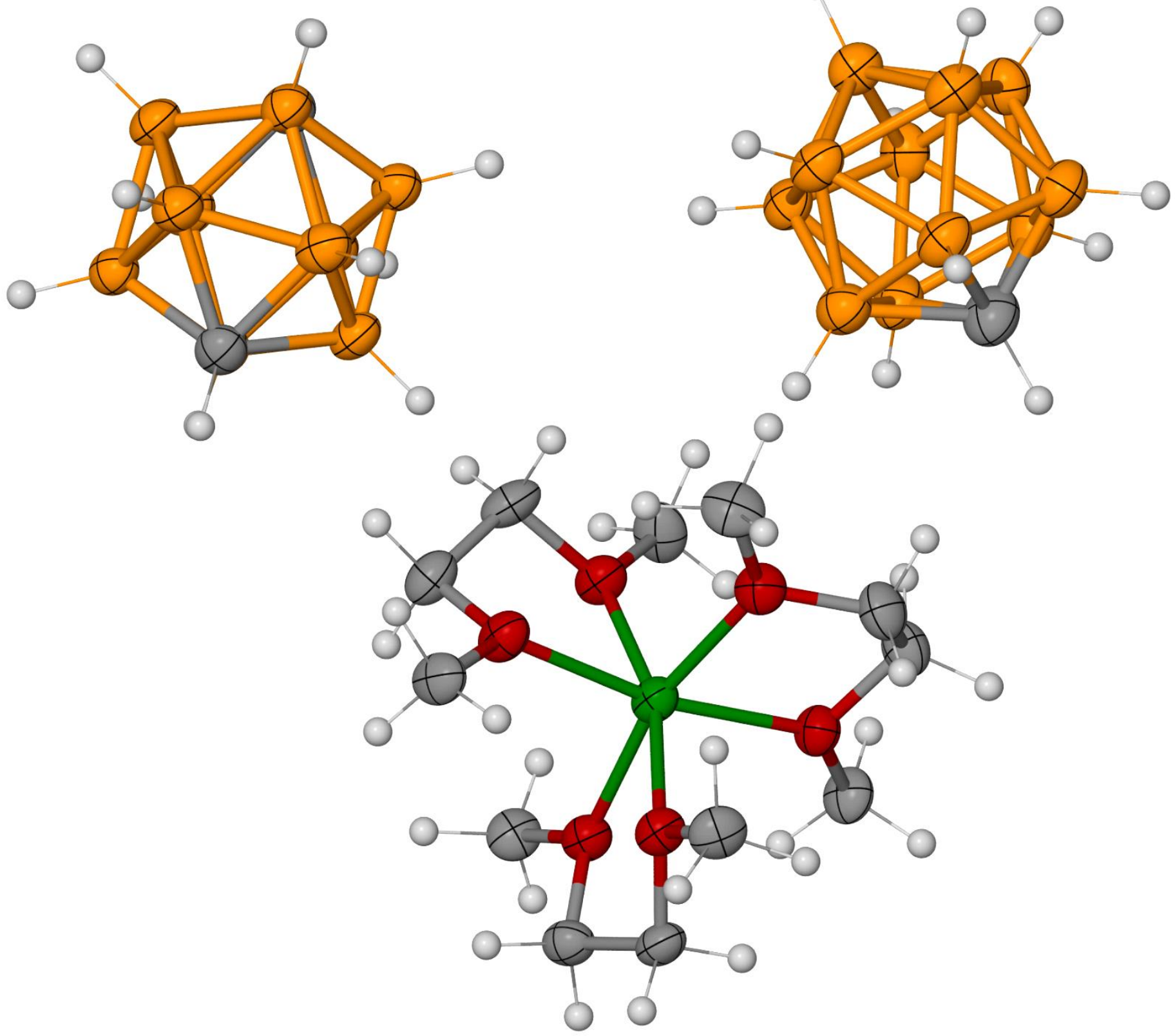

Figure S22. Thermal ellipsoid plot of $\left[\mathrm{Mg}(\mathrm{DME})_{3}\right]\left(\mathrm{CB}_{11} \mathrm{H}_{12}\right)_{2}(4)$, shown at $50 \%$ probability level. Element colors: $\mathrm{Mg}$ (green), O (red), B (orange), C (grey), H (white). 

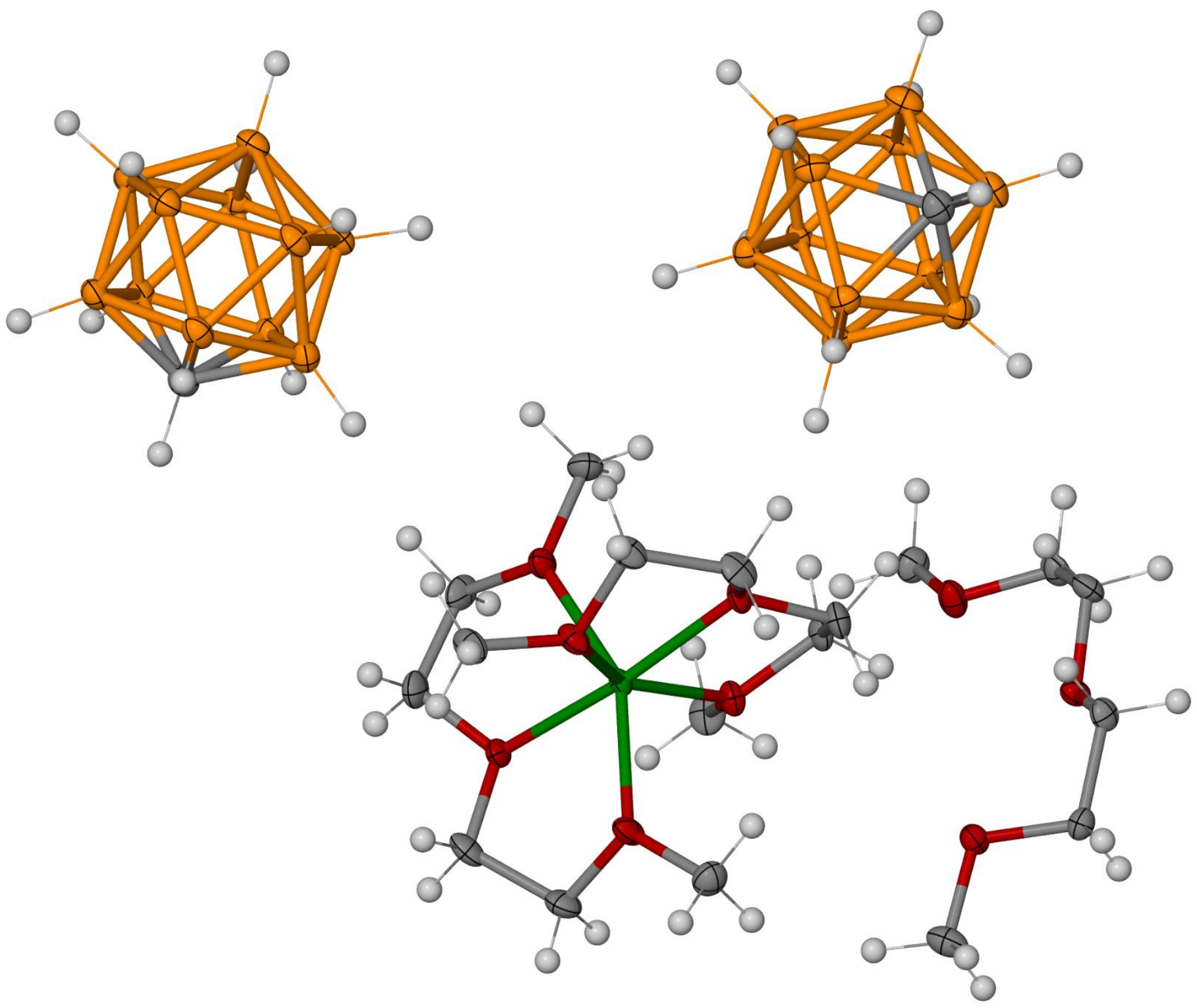

Figure S23. Thermal ellipsoid plot of $\left[\mathrm{Mg}(\mathrm{G} 2)_{2}\right]\left(\mathrm{CB}_{11} \mathrm{H}_{12}\right)_{2} \cdot(\mathrm{G} 2)(\mathbf{5})$, shown at $50 \%$ probability level. Element colors: $\mathrm{Mg}$ (green), O (red), B (orange), C (grey), H (white). 


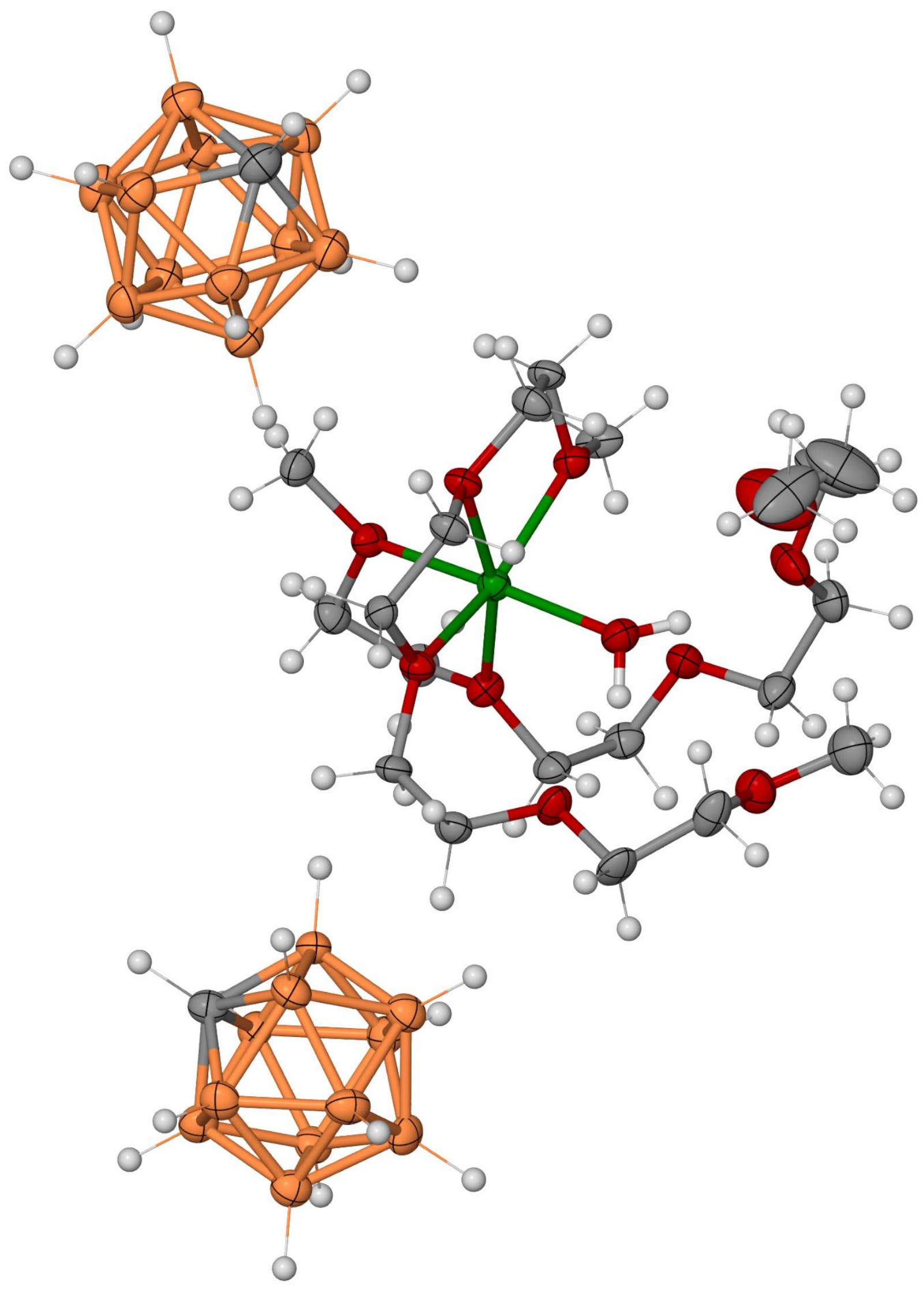

Figure S24. Thermal ellipsoid plot of one of the three independent $\left[\mathrm{Mg}(\mathrm{G} 4)_{2}\left(\mathrm{H}_{2} \mathrm{O}\right)\right]\left(\mathrm{CB}_{11} \mathrm{H}_{12}\right)_{2}$ molecules found in the unit cell of $\mathbf{6}$, shown at 50\% probability level. The major orientation of $\mathrm{G} 4$ is displayed. Element colors: $\mathrm{Mg}$ (green), O (red), B (orange), C (grey), $\mathrm{H}$ (white). 


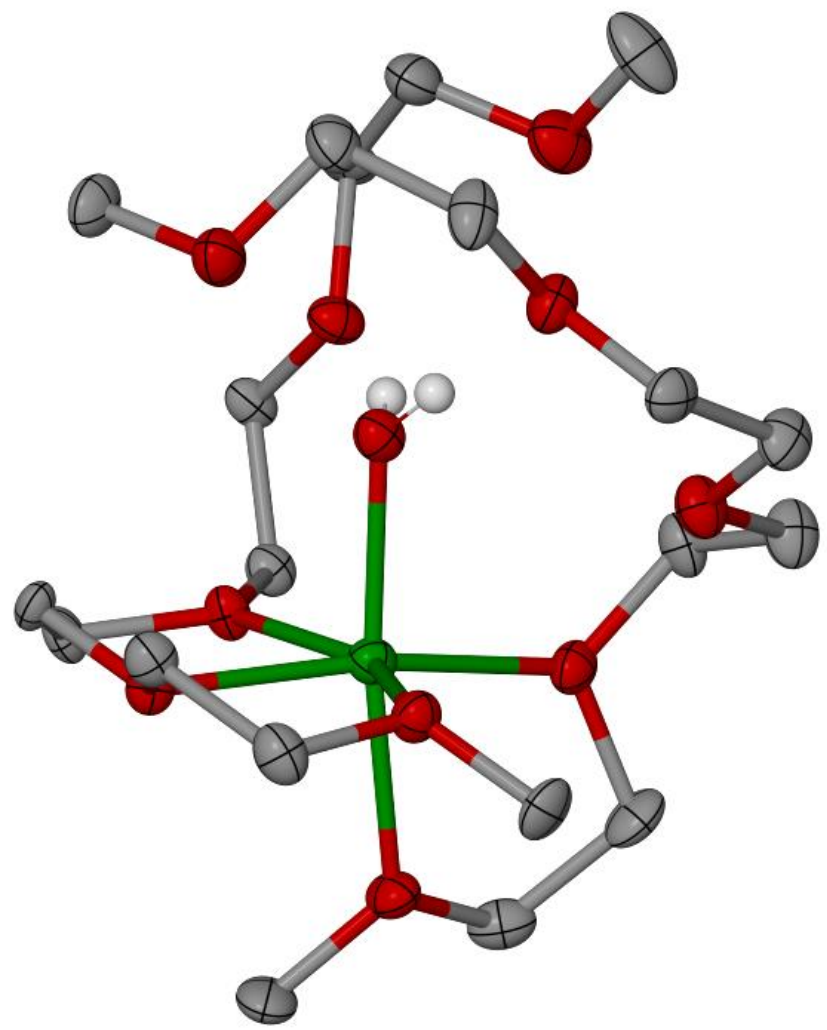

Figure S25. Mg cation coordination environment in $\left[\mathrm{Mg}(\mathrm{G} 4)_{2}\left(\mathrm{H}_{2} \mathrm{O}\right)\right]\left(\mathrm{CB}_{11} \mathrm{H}_{12}\right)_{2}(\mathbf{6})$. Thermal ellipsoids drawn at $50 \%$ probability level. Hydrogen atoms of G4 ligand are omitted for clarity. Element colors: $\mathrm{Mg}$ (green), $\mathrm{O}$ (red), $\mathrm{C}$ (grey), $\mathrm{H}$ (white). 


\section{Electrochemistry}

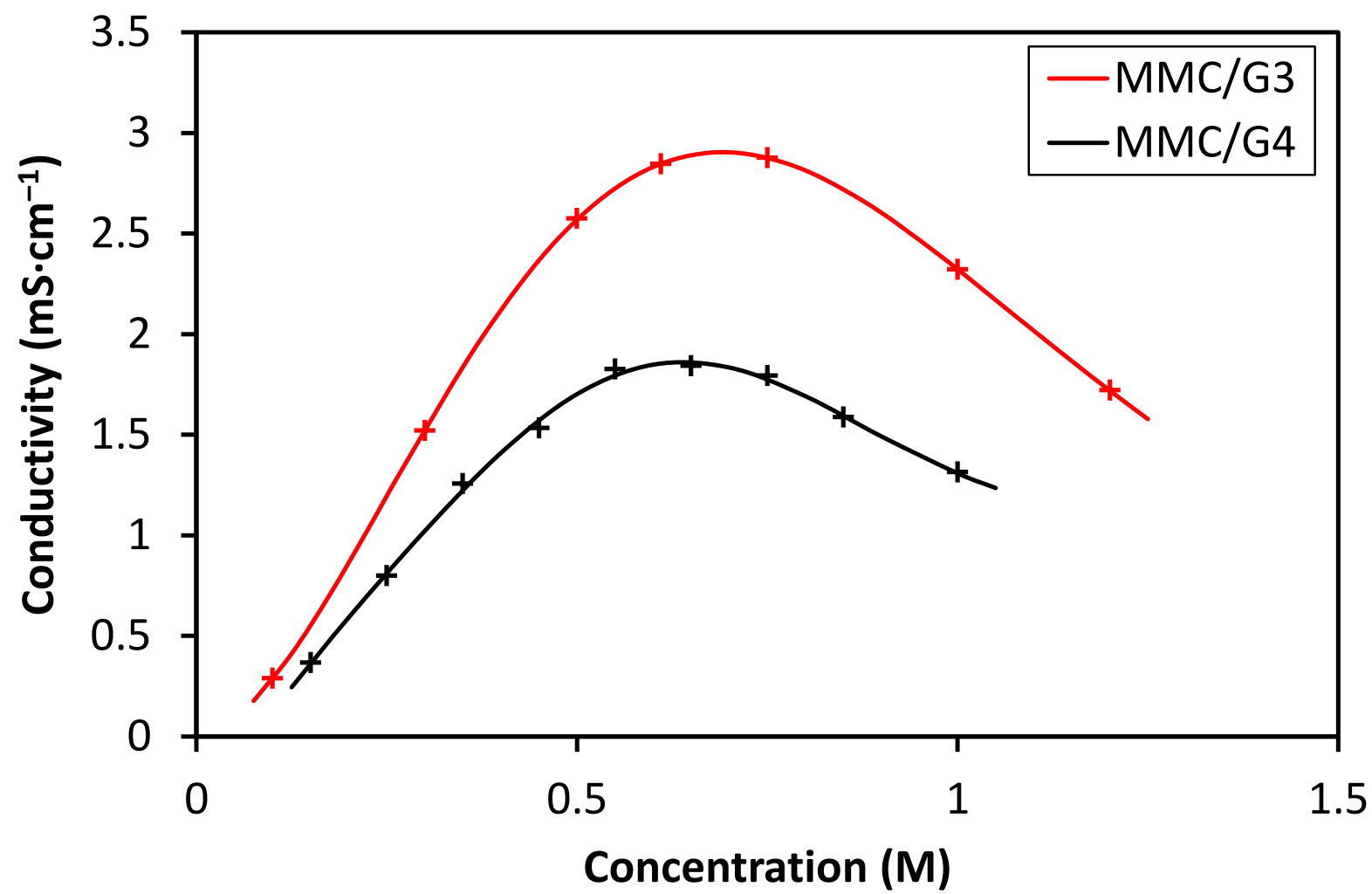

Figure S26. Ionic conductivity of MMC/G3 and MMC/G4 solutions as function of salt concentration.
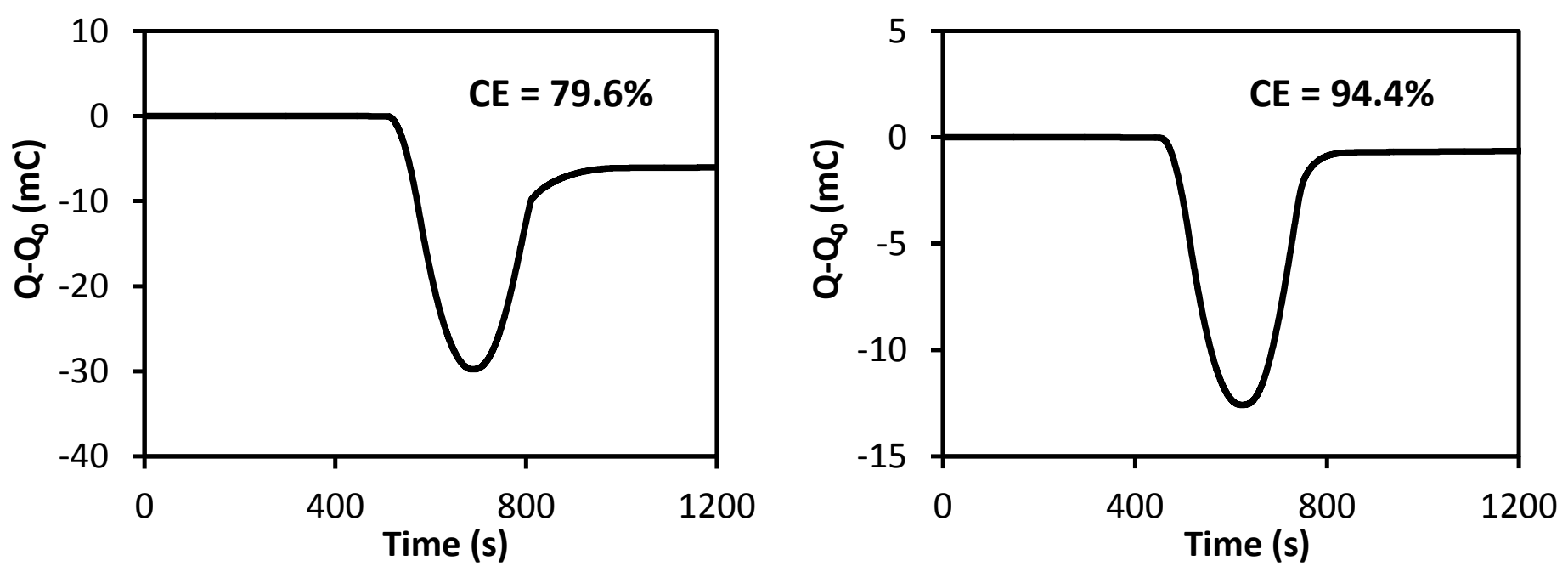

Figure S27. Charge balance of Mg deposition/stripping for the first scan of a cyclic voltammetry test on Pt electrode of $0.75 \mathrm{M} \mathrm{MMC/G3} \mathrm{(left)} \mathrm{and} 0.75 \mathrm{M}$ MMC/G4 (right) electrolytes collected at $5 \mathrm{mV} \cdot \mathrm{s}^{-1}$. 


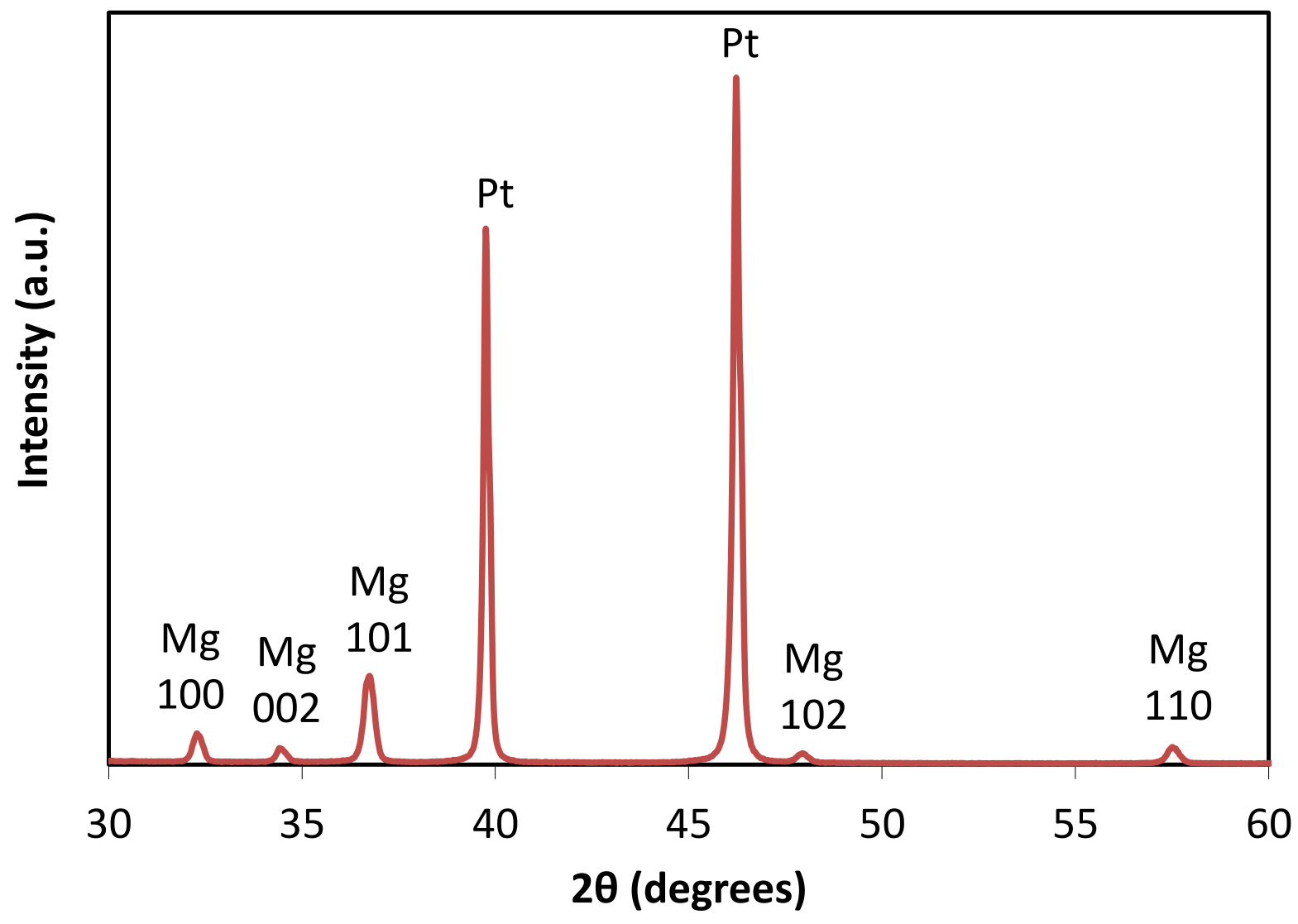

Figure S28. XRD plot of a Pt disk following galvanostatic deposition of Mg from 0.75 M MMC/G4 electrolyte.
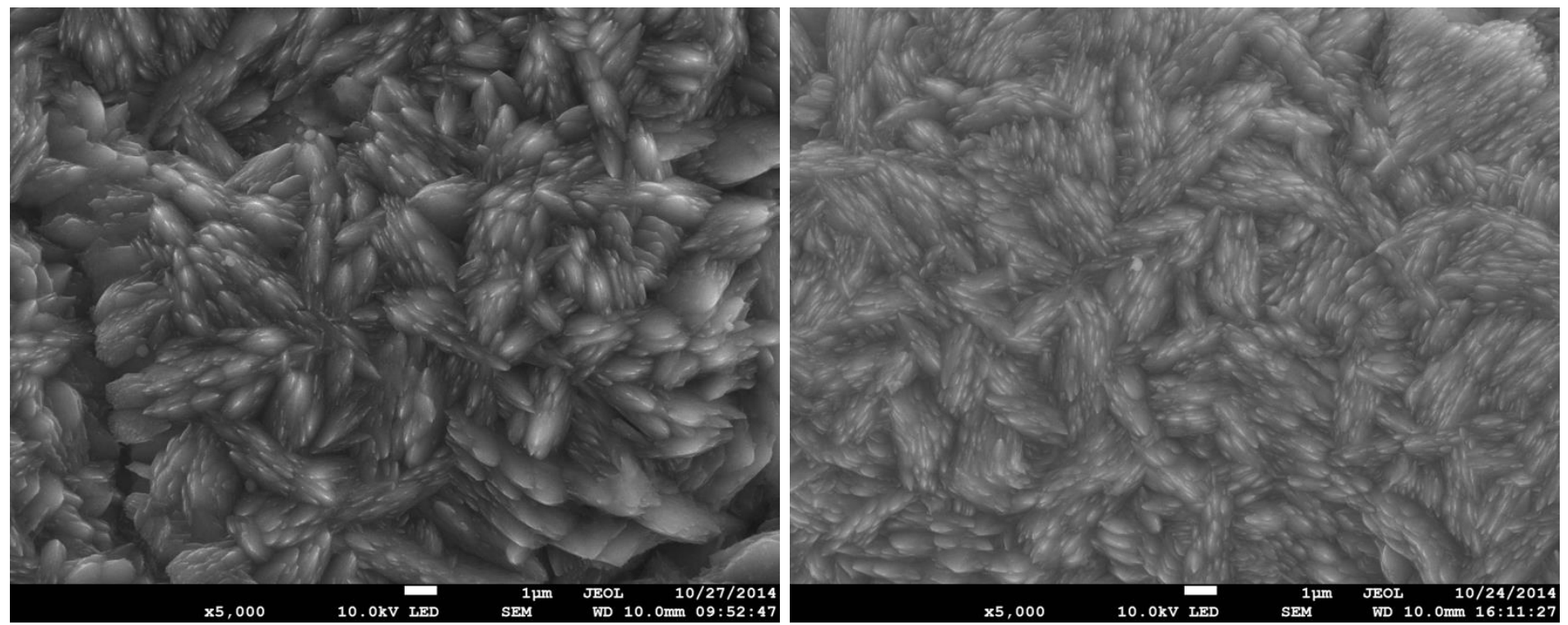

Figure S29. SEM micrographs of solid deposited upon galvanostatic Mg plating onto a Pt working electrode at $5 \mathrm{~mA} \mathrm{~cm}{ }^{-2}$ from $0.75 \mathrm{M}$ MMC/G4 electrolyte. 


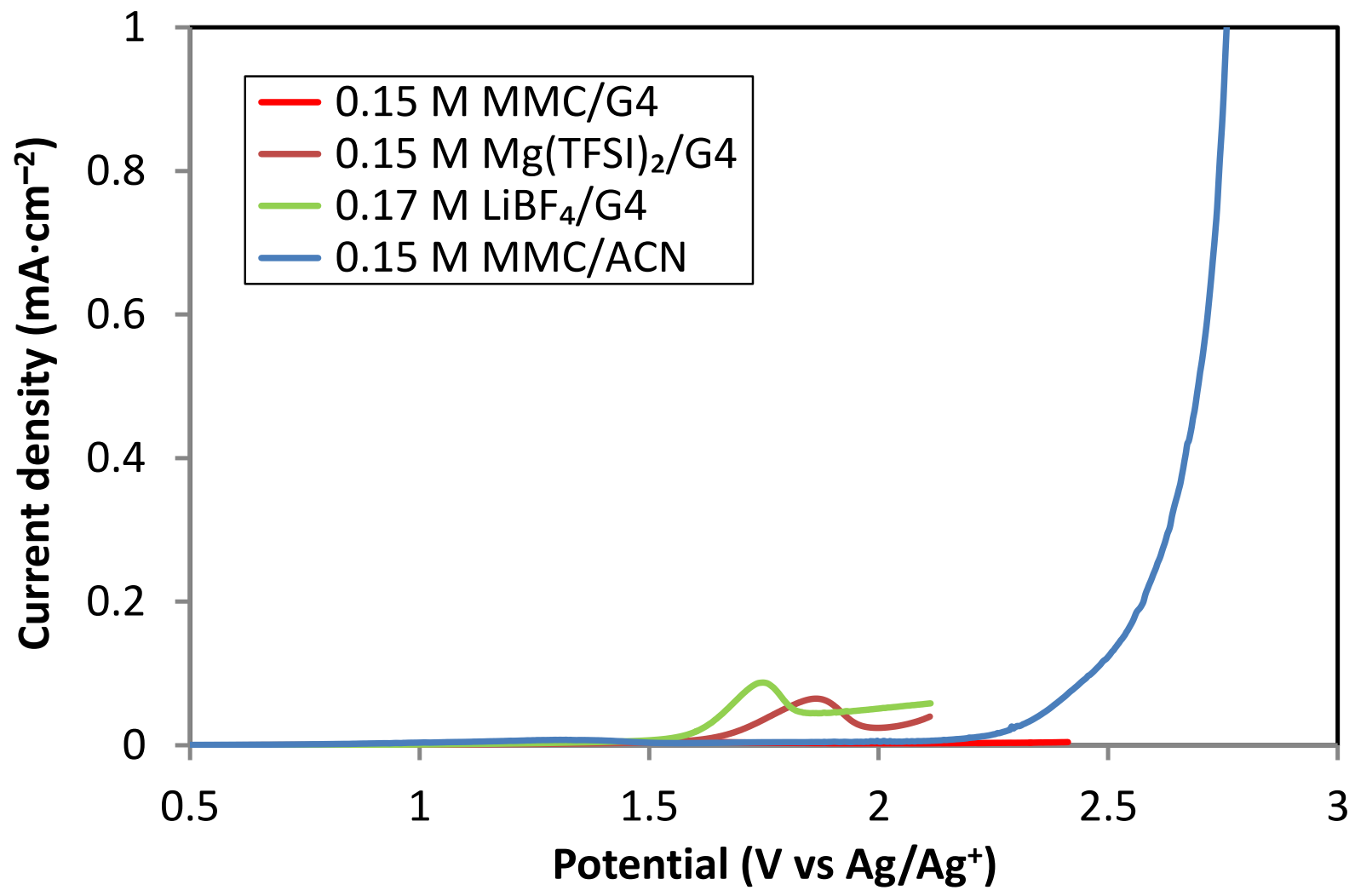

Figure S30. Linear sweep voltammograms of various electrolyte solutions on Pt electrode collected at $0.05 \mathrm{mV} \cdot \mathrm{s}^{-1}$.

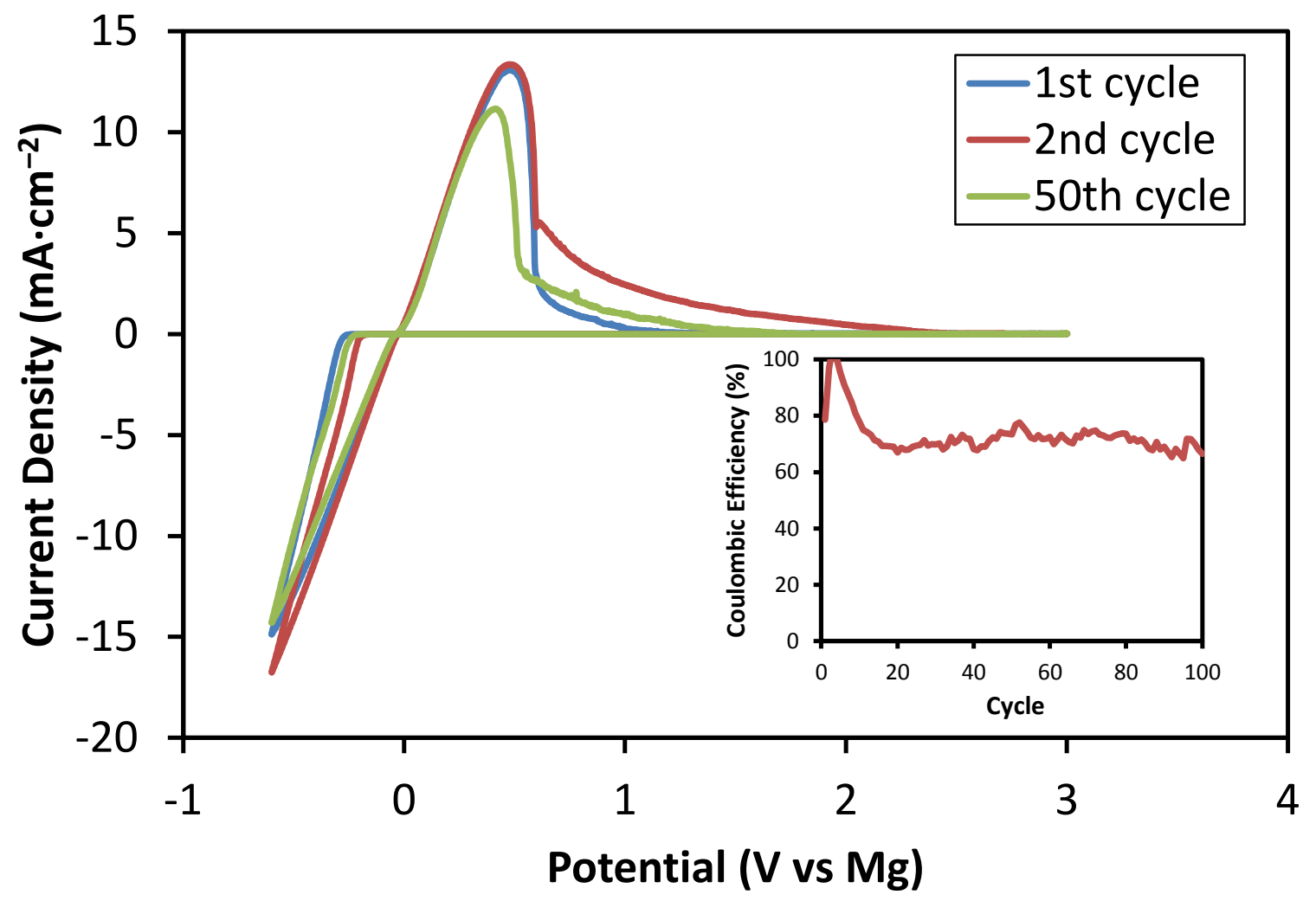

Figure S31. Cyclic voltammograms of $0.75 \mathrm{M}$ MMC/G3 electrolyte on a Pt electrode collected within the potential range of $-0.6-3.0 \mathrm{~V}$ (vs. $\mathrm{Mg}$ ) collected at $5 \mathrm{mV} \cdot \mathrm{s}^{-1}$ (inset: cycling efficiencies of $\mathrm{Mg}$ deposition and dissolution). 


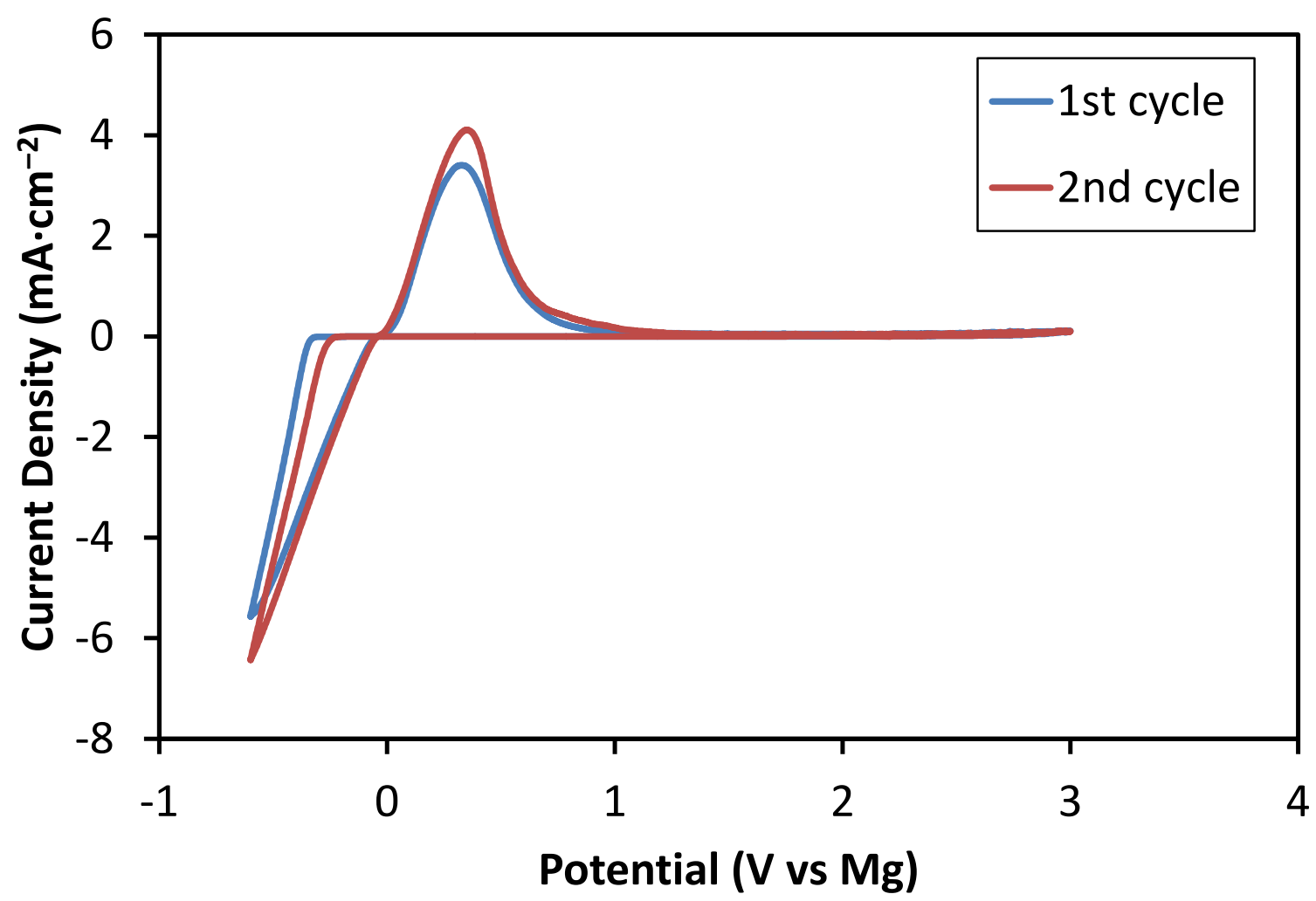

Figure S32. Cyclic voltammograms on a 316SS electrode in $0.75 \mathrm{M}$ MMC/G4 electrolyte collected within the potential range of $-0.6-3.0 \mathrm{~V}\left(\mathrm{vs} . \mathrm{Mg}\right.$ ) collected at $5 \mathrm{mV} \cdot \mathrm{s}^{-1}$.

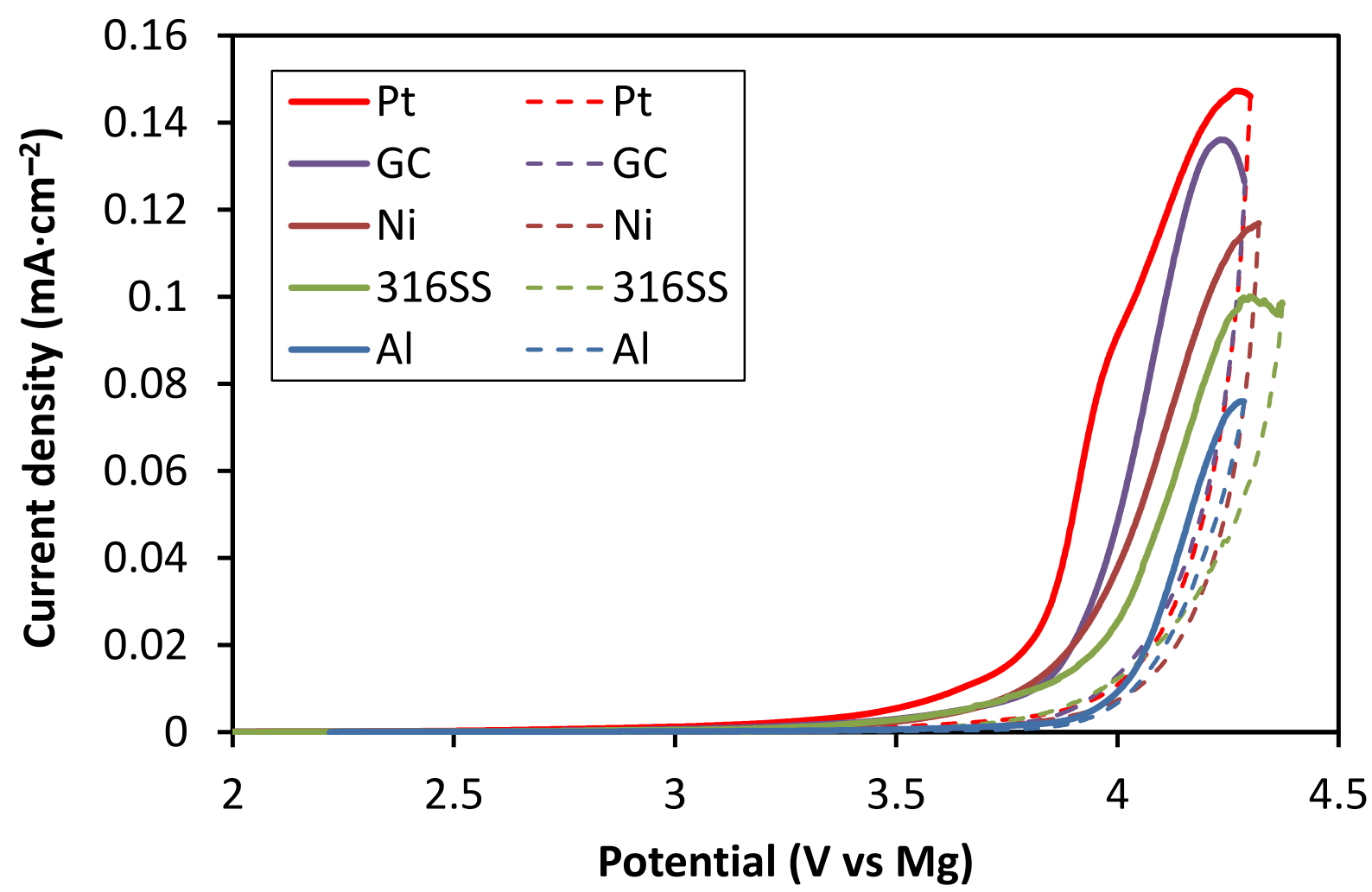

Figure S33. Linear sweep voltammograms of $0.75 \mathrm{M}$ MMC/G4 electrolyte on Al, Ni, SS, GC and Pt electrodes collected at $5 \mathrm{mV} \cdot \mathrm{s}^{-1}$. Dashed lines represent the reverse scan. 
Table S2. Summary of EDS analysis of 316SS disk electrode surface and ICP analysis of electrolyte solution before and after chronoamperometry experiments.

\begin{tabular}{|c|cc|cccc|}
\cline { 2 - 8 } \multicolumn{1}{c|}{} & \multicolumn{2}{c|}{$3.0 \mathrm{~V}$} & \multicolumn{2}{c|}{$3.5 \mathrm{~V}$} \\
\multicolumn{1}{c|}{ Before } & After & \multicolumn{2}{c|}{ Before } & \multicolumn{2}{c|}{ After } \\
& EDS (\%) & EDS (\%) & ICP $^{\prime}$ & EDS $(\%)$ & ICP & EDS (\%) \\
\hline $\mathrm{Fe}$ & $62.2 \pm 0.8$ & $62.8 \pm 0.8$ & $<108 \mathrm{ppm}^{a}$ & $62.5 \pm 0.8$ & $<1.8 \mathrm{ppm}^{b}$ & $62.3 \pm 0.8$ \\
$\mathrm{Cr}$ & $16.2 \pm 0.4$ & $16.3 \pm 0.4$ & $<44 \mathrm{ppm}^{a}$ & $16.4 \pm 0.4$ & $<4.4 \mathrm{ppm}^{b}$ & $16.2 \pm 0.4$ \\
$\mathrm{Ni}$ & $14.2 \pm 1.0$ & $13.5 \pm 1.0$ & $<36 \mathrm{ppm}^{a}$ & $14.0 \pm 1.0$ & $<1.5 \mathrm{ppm}^{b}$ & $14.3 \pm 1.0$ \\
$\mathrm{Mo}$ & $2.5 \pm 0.2$ & $2.4 \pm 0.2$ & N/A & $2.5 \pm 0.2$ & N/A & $2.5 \pm 0.2$ \\
\hline
\end{tabular}

a. Detection limit for a $15 \mu \mathrm{L}$ sample.

$b$. Detection limit for a $400 \mu \mathrm{L}$ sample.

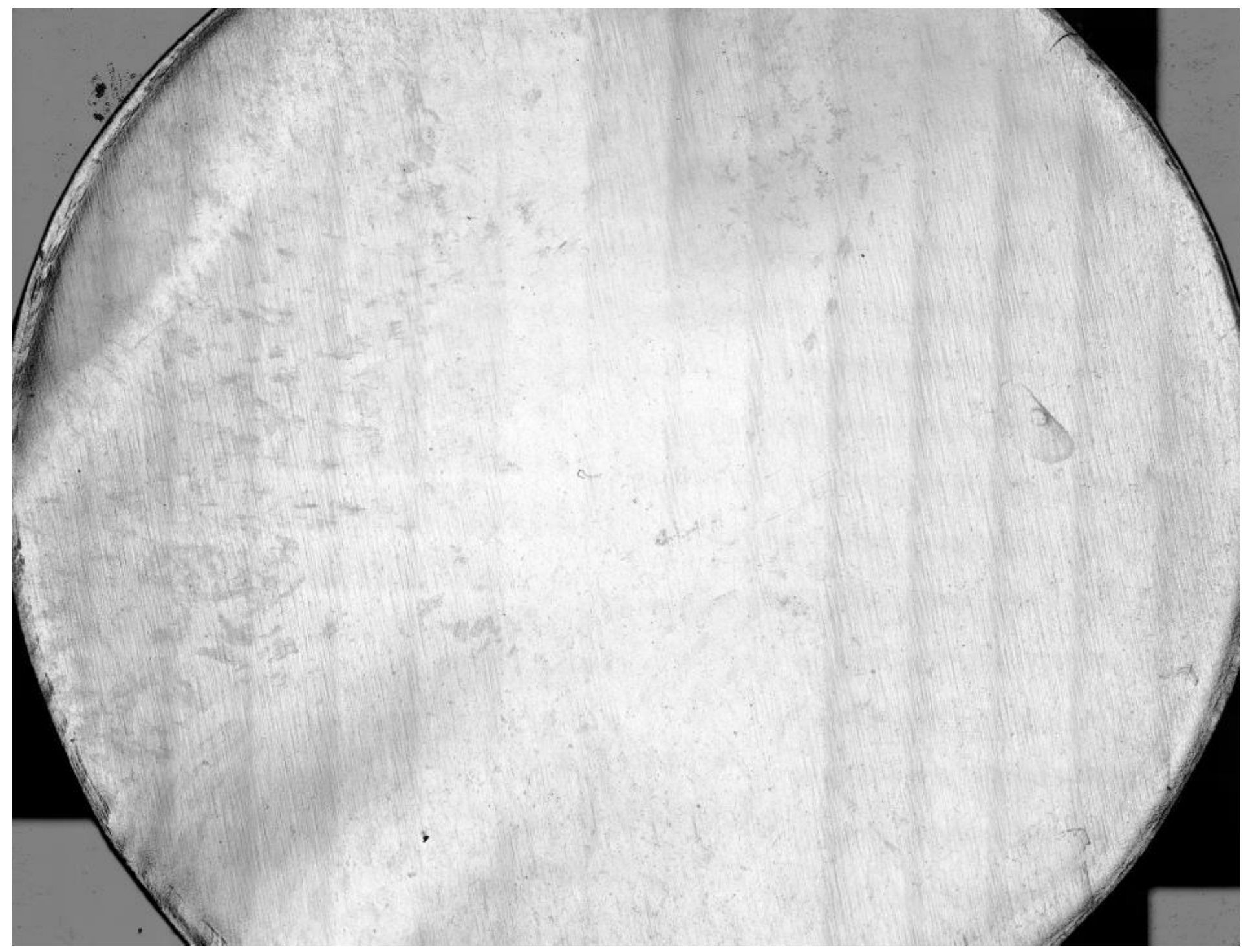

Figure S34. Laser microscope image of the 316SS disk after chronoamperometry at $3.0 \mathrm{~V}$ for $48 \mathrm{~h}$. Diameter disk: $19.0 \mathrm{~mm}$, exposed area: $1.33 \mathrm{~cm}^{2}$. 

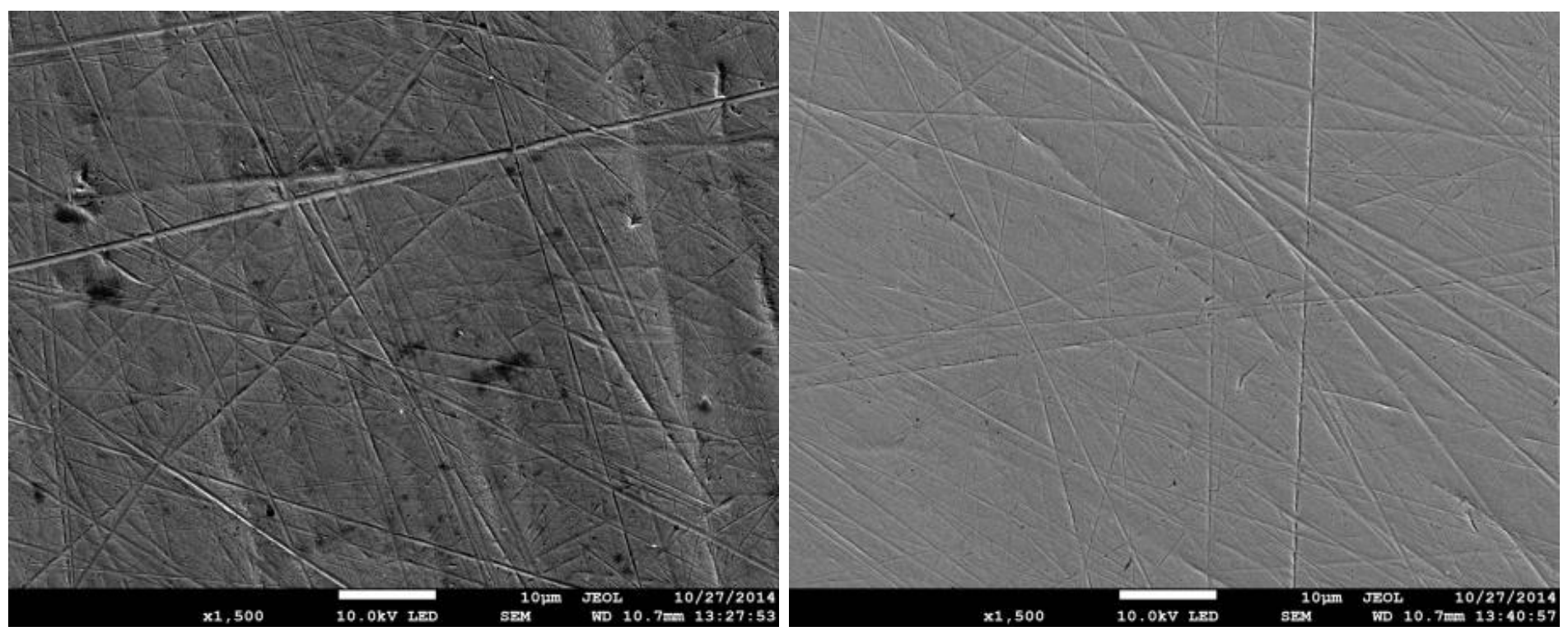

EDS Layered Image 1

EDS Layered Image 2
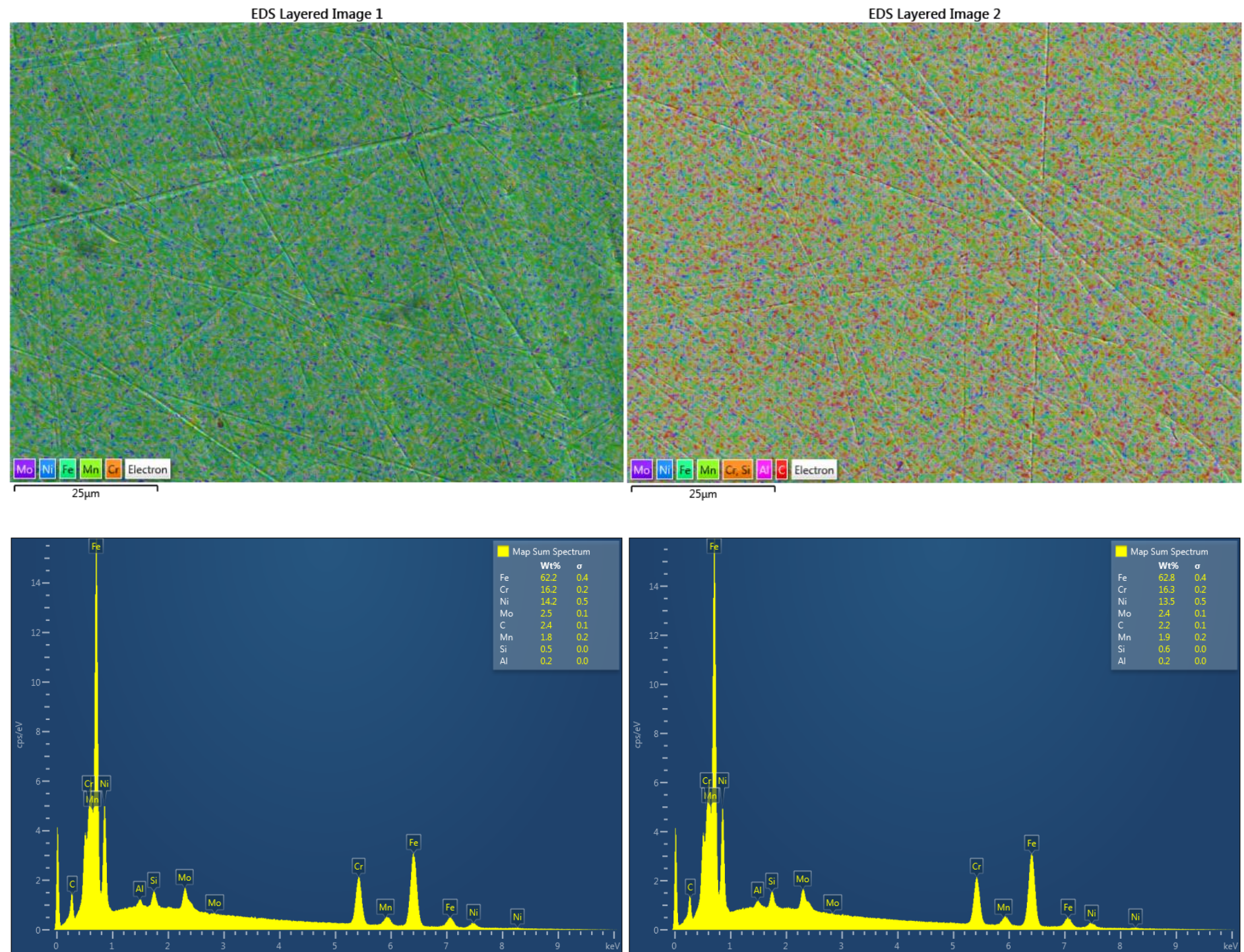

Figure S35. Surface information of the 316SS disk before (left) and after (right) chronoamperometry at $3.0 \mathrm{~V}$ for 48 h. Top: SEM images; center: EDS layered images; bottom: EDS map spectra. 


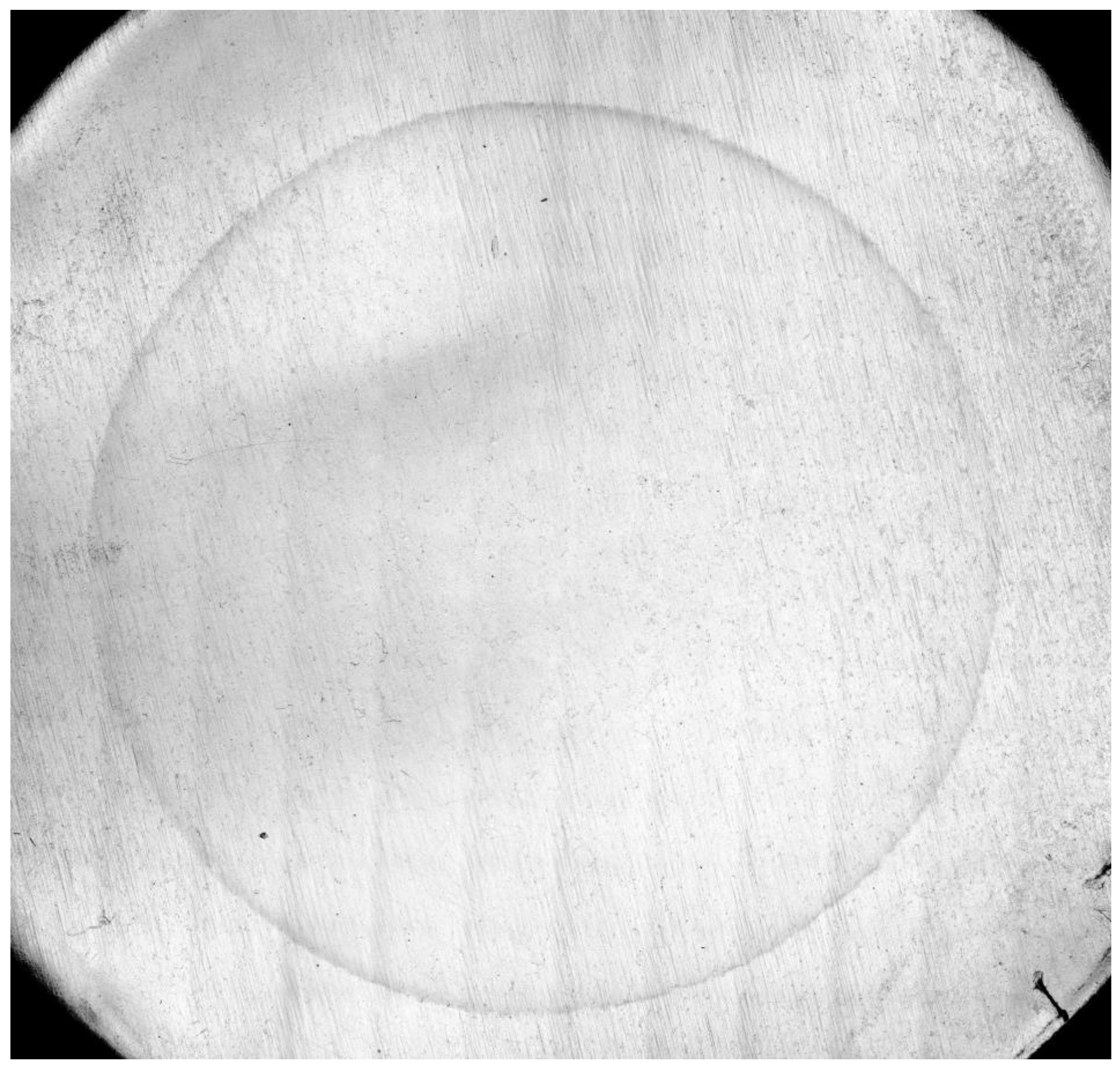

Figure S36. Laser microscope image of the 316SS disk after chronoamperometry at $3.5 \mathrm{~V}$ for $48 \mathrm{~h}$. Diameter disk: $19.0 \mathrm{~mm}$, exposed area: $1.33 \mathrm{~cm}^{2}$. 

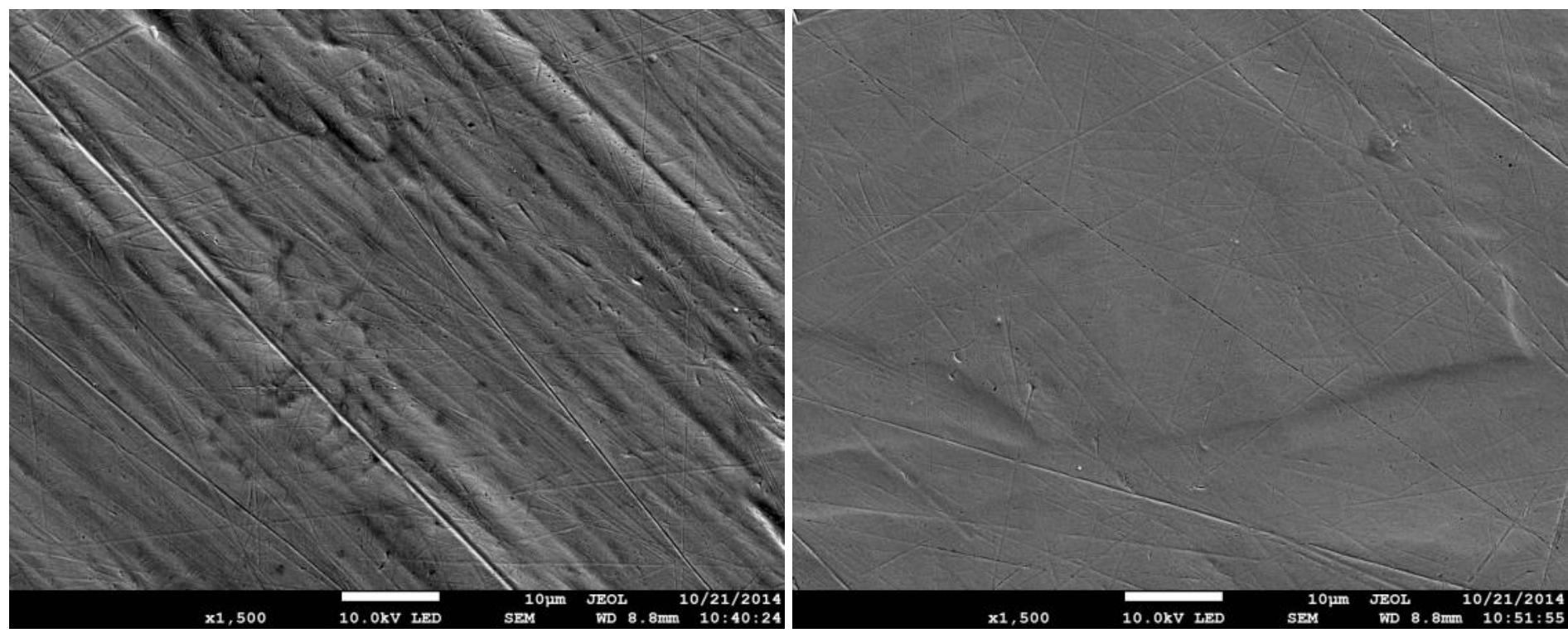

EDS Layered Image 1

EDS Layered Image 2
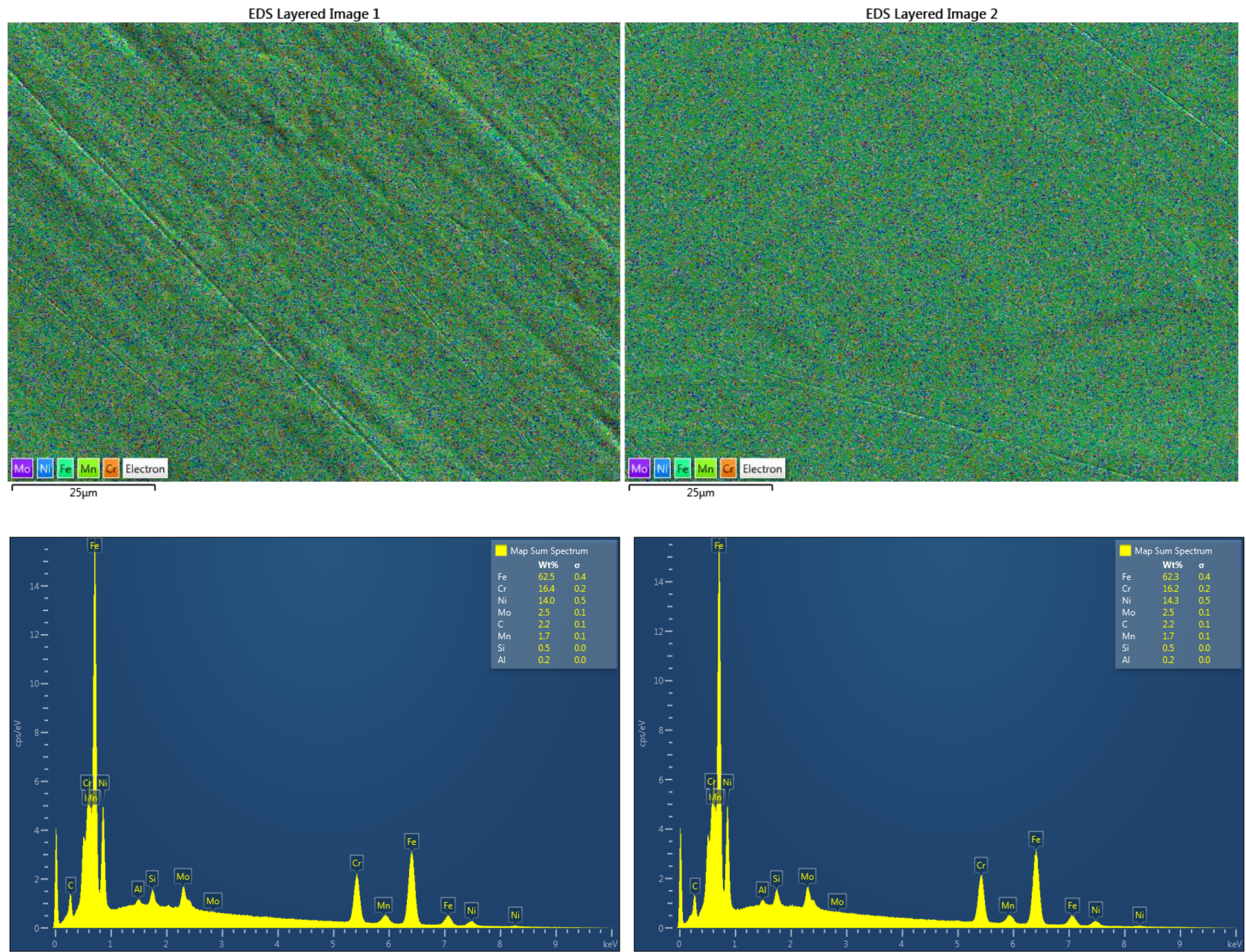

Figure S37. Surface information of the 316SS disk before (left) and after (right) chronoamperometry at $3.5 \mathrm{~V}$ for 48 h. Top: SEM images; center: EDS layered images; bottom: EDS map spectra. 


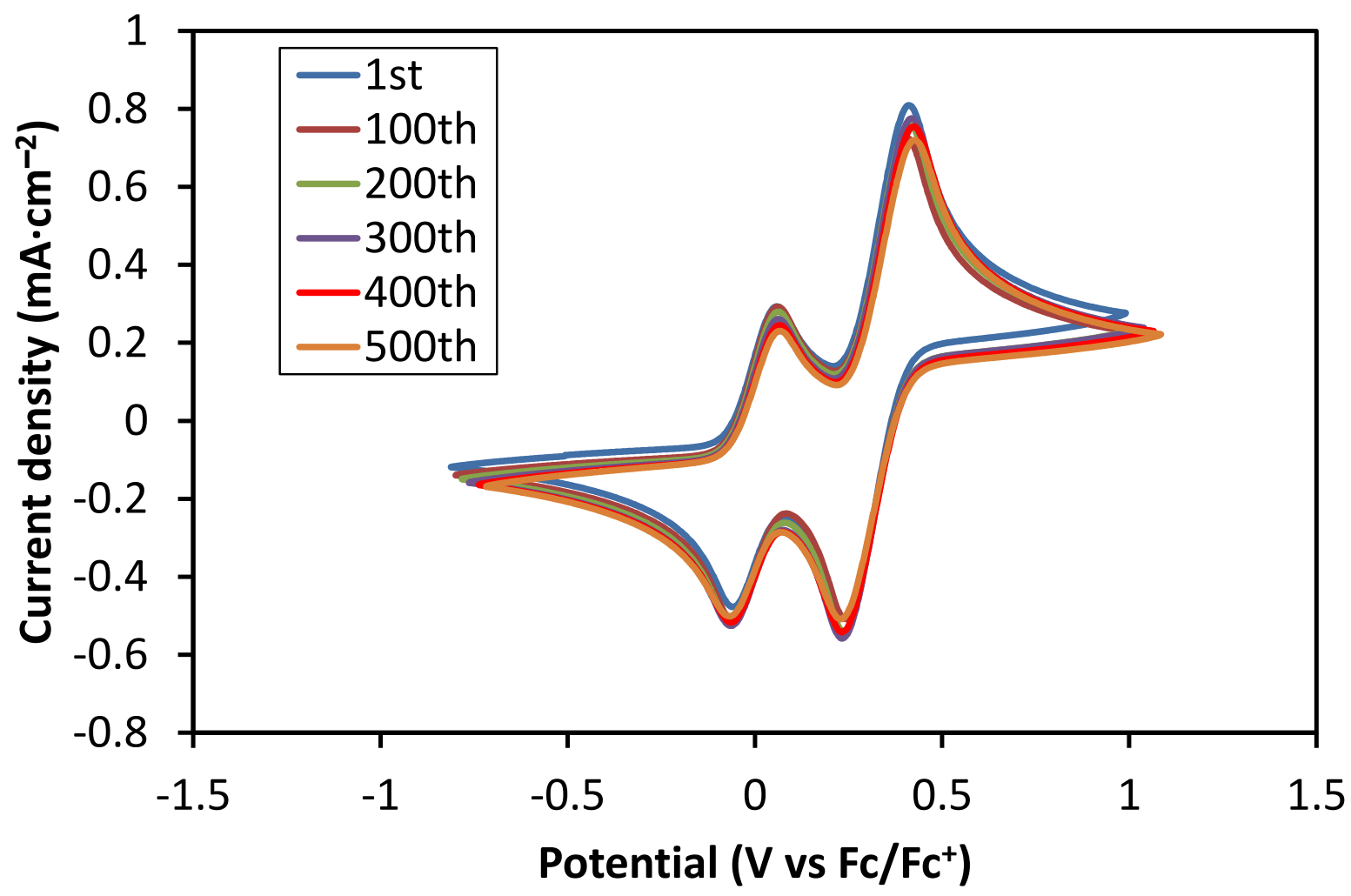

Figure S38. Cyclic voltammograms of $0.003 \mathrm{M}$ 4-MeO-TEMPO in $0.75 \mathrm{M}$ MMC/G4 on Pt electrode collected at $100 \mathrm{mV} \cdot \mathrm{s}^{-1}$.

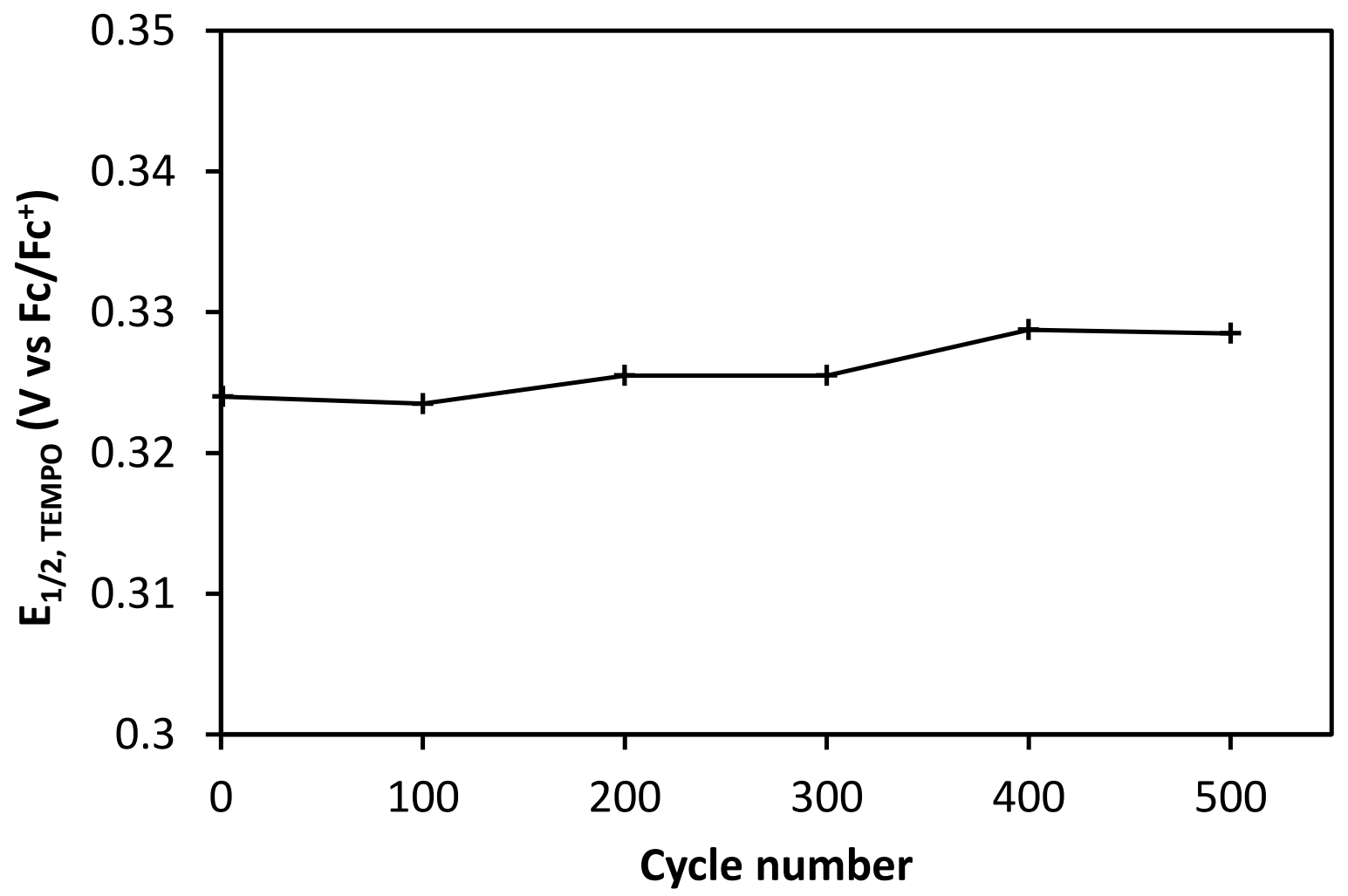

Figure S39. Half-wave potential of 4-MeO-TEMPO redox in 0.75 M MMC/G4 with respect to cycle number. 


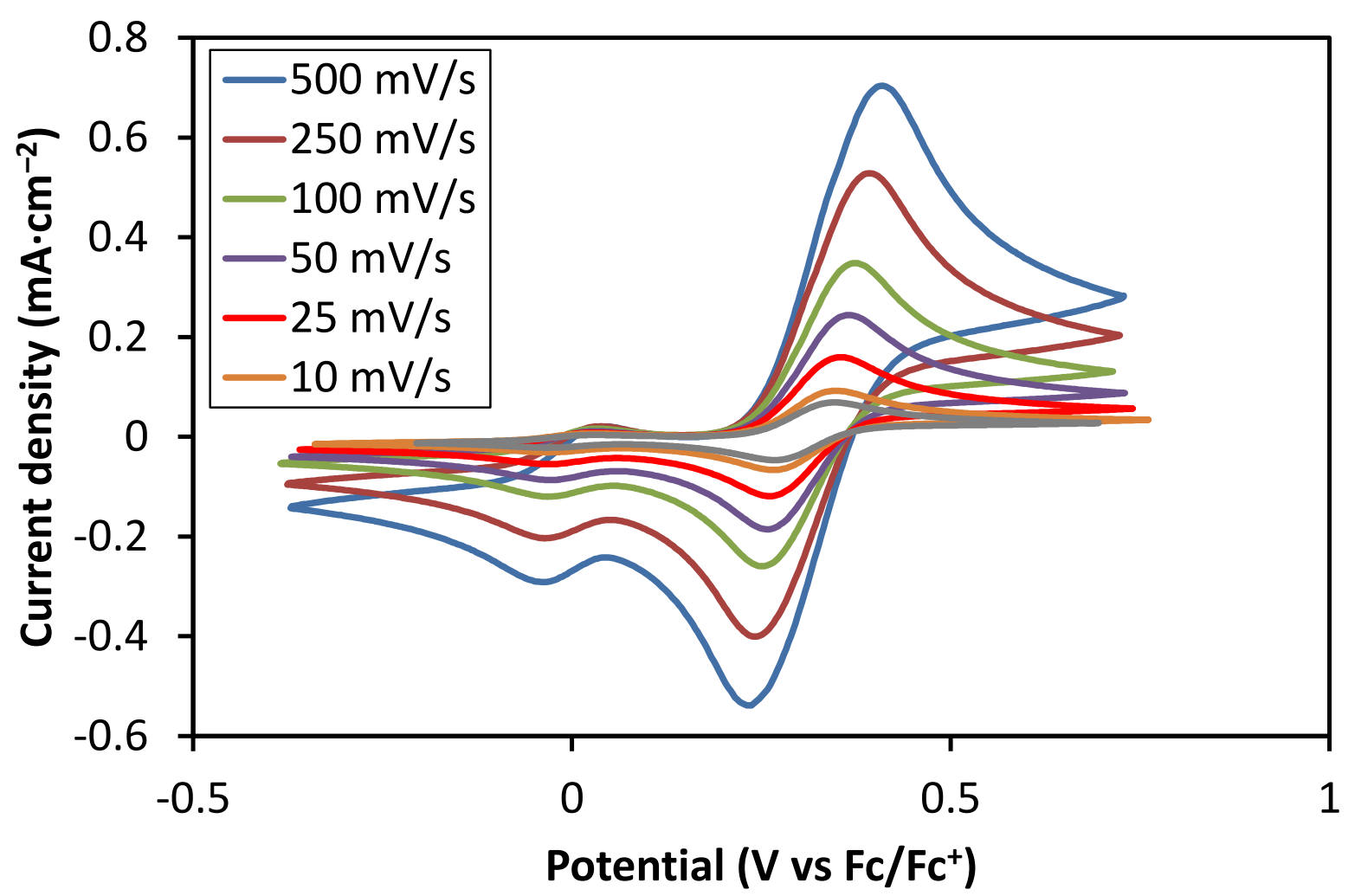

Figure S40. Cyclic voltammograms of 0.003 M 4-MeO-TEMPO in $0.75 \mathrm{M}$ MMC/G4 on Pt electrode at scan rates ranging from $10-500 \mathrm{mV} \mathrm{s}^{-1}$.

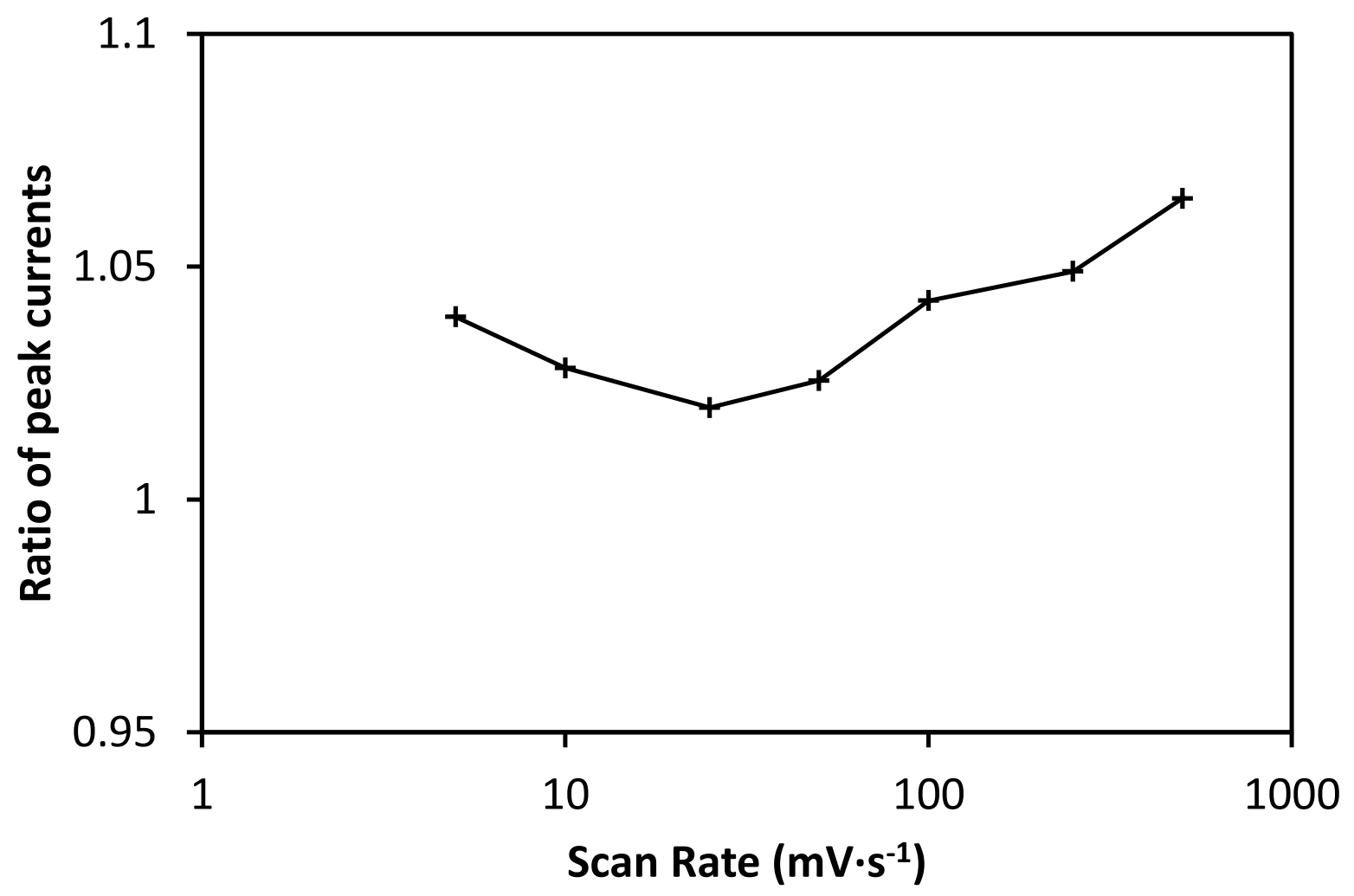

Figure S41. Ratio of the oxidation and reduction peak currents with respect to scan rate. 


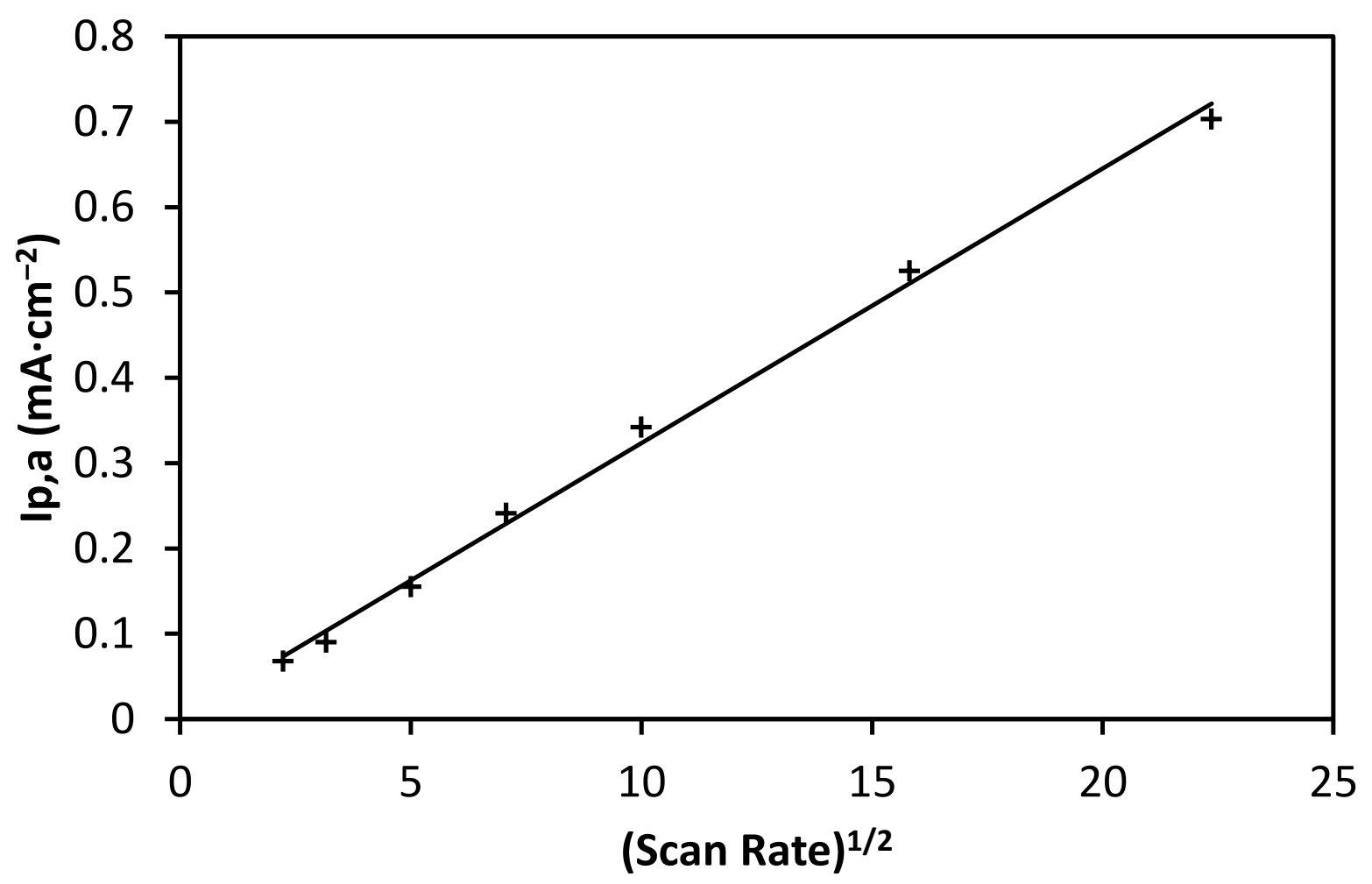

Figure S42. Linear dependence of anodic peak current density on the square-root of the scan rate for the redox couple 4-MeO-TEMPO in $0.75 \mathrm{M}$ MMC/G4.

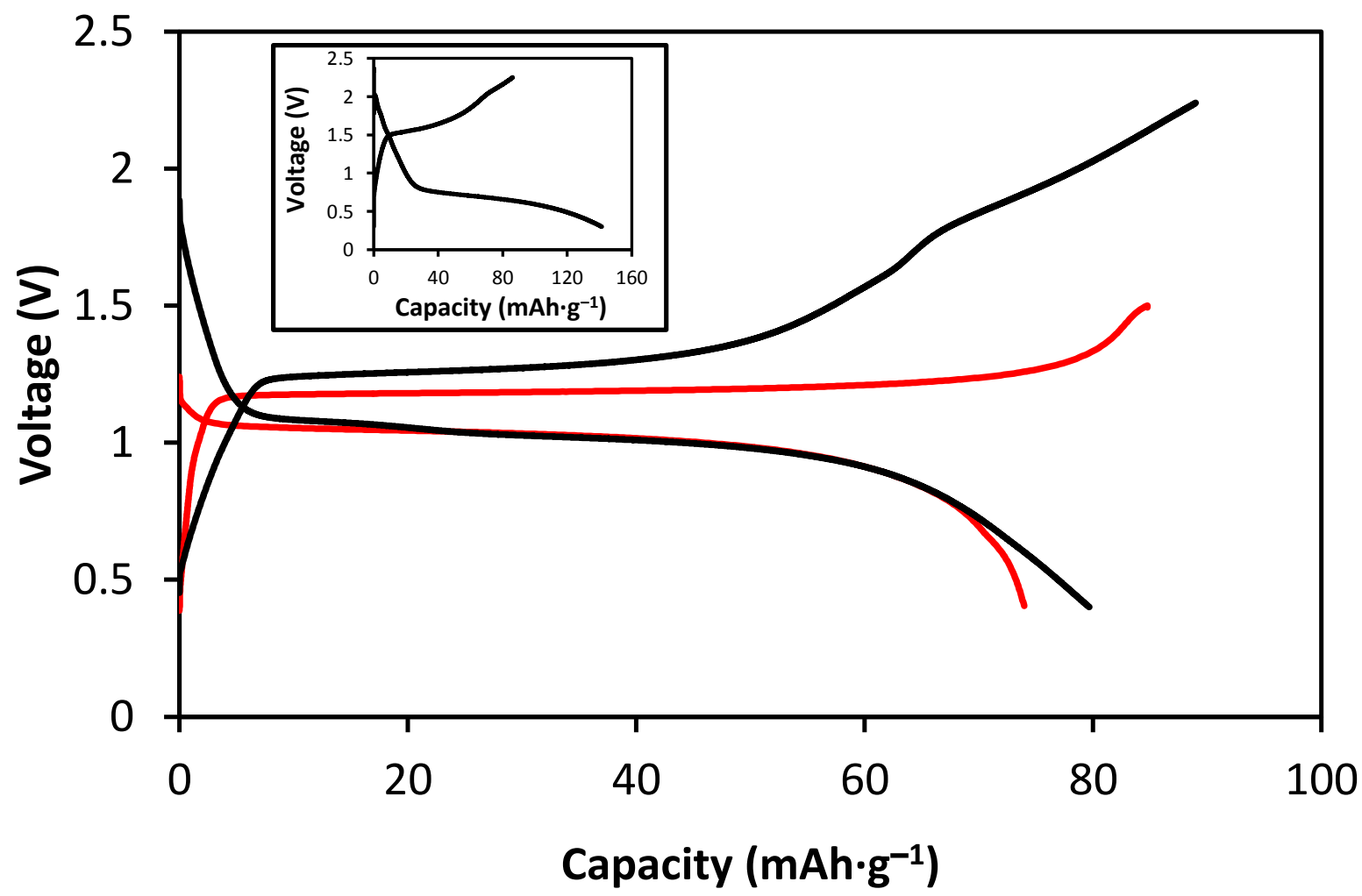

Figure S43. Charge/discharge profiles at the cycle 10 of a rechargeable battery with $0.75 \mathrm{M} \mathrm{MMC/G4} \mathrm{(black} \mathrm{line)}$ and APC (red line) as the electrolyte, a Mg anode, and a Chevrel phase cathode. The current density was $10 \mathrm{~mA} \cdot \mathrm{g}^{-1}$. (Inset: first charge/discharge profile for battery using $0.75 \mathrm{M}$ MMC/G4 electrolyte). 


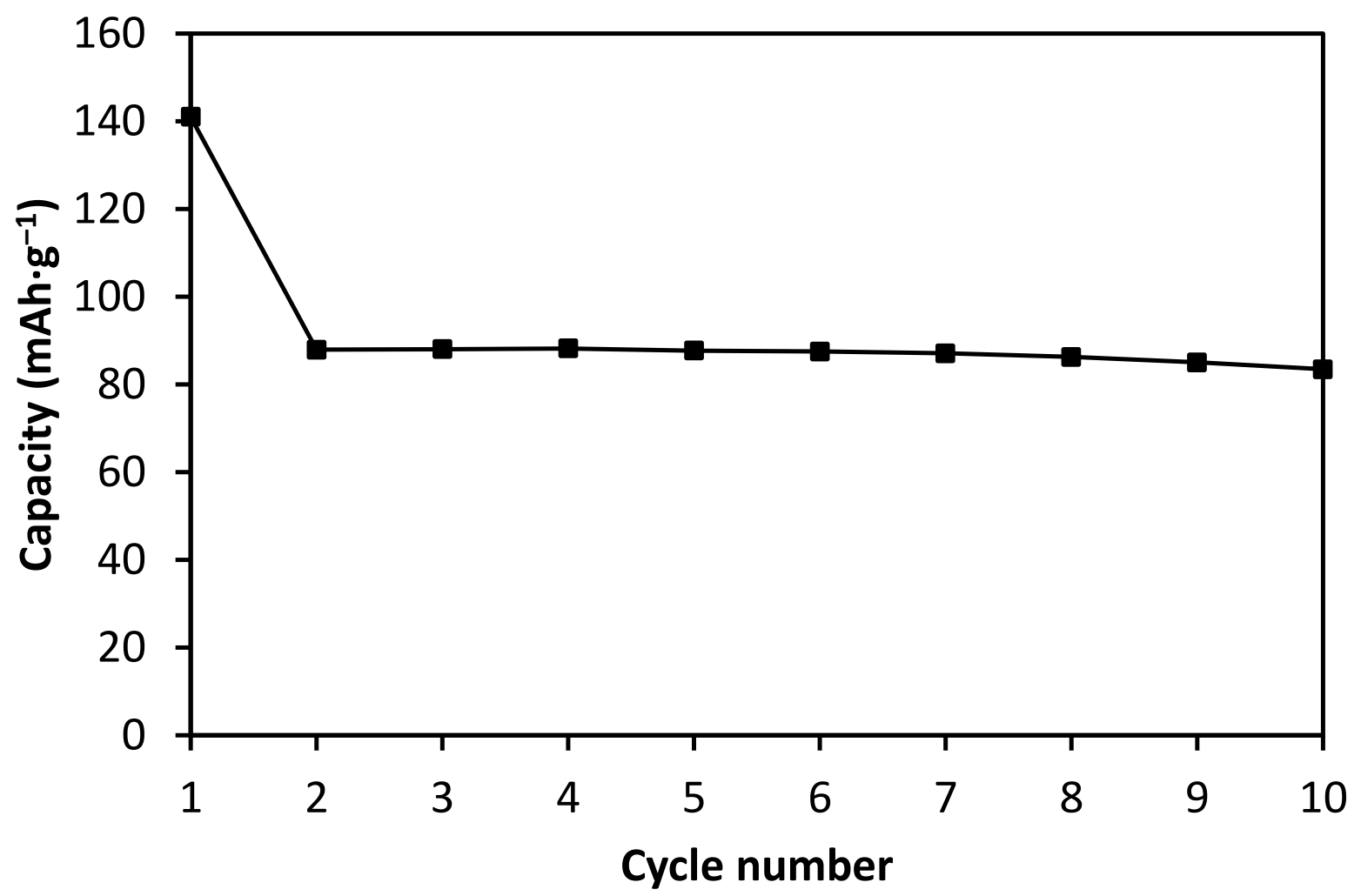

Figure S44. Capacity of rechargeable battery with $0.75 \mathrm{M} \mathrm{MMC/G4}$ as the electrolyte, a Mg anode, and a Chevrel phase cathode. The current density was $10 \mathrm{~mA} \cdot \mathrm{g}^{-1}$.

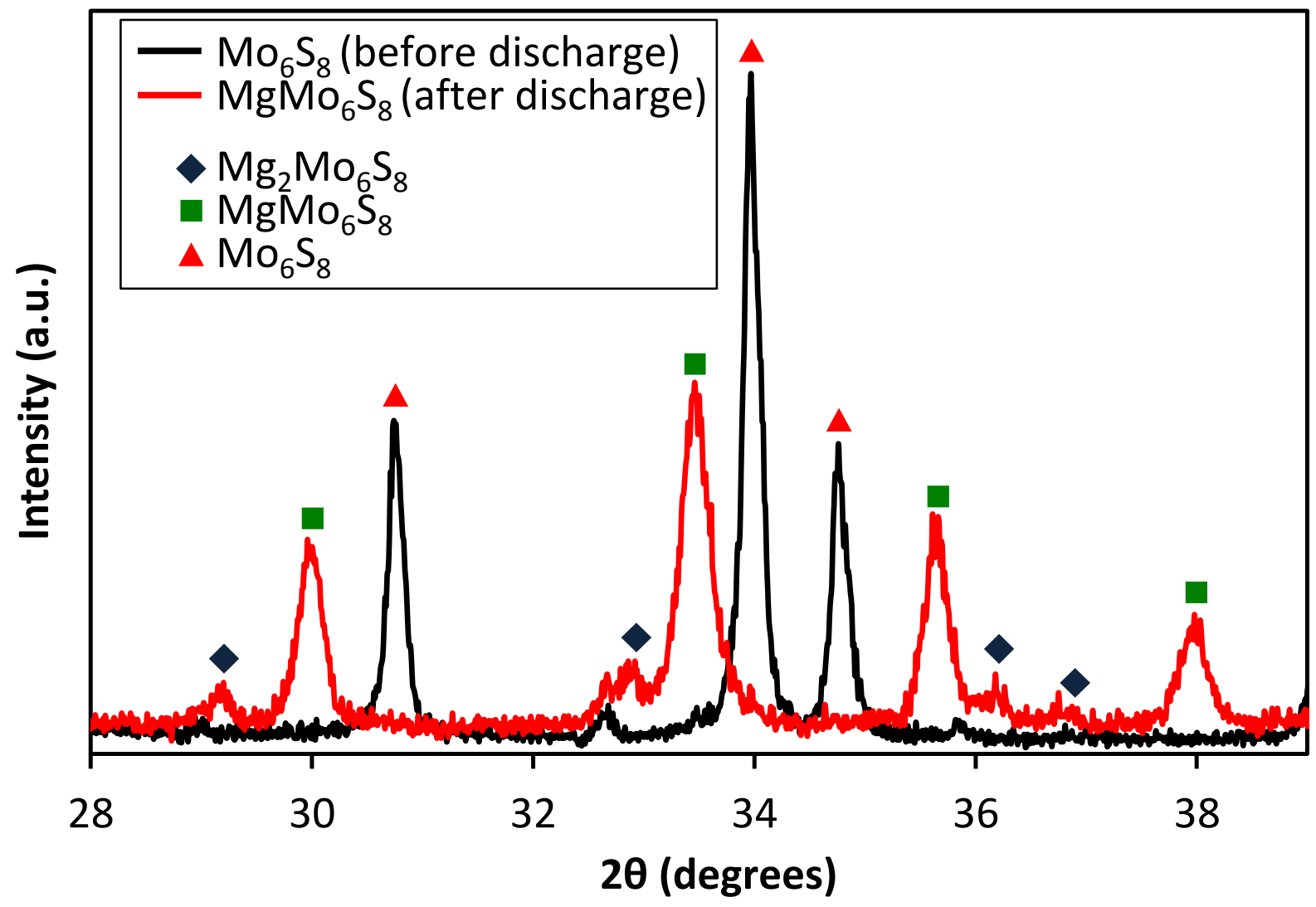

Figure S45. XRD results of the cathode before/after the $1^{\text {st }}$ discharge illustrating the characteristic peak shifts resulting from the magnesiation of $\mathrm{Mo}_{6} \mathrm{~S}_{8}{ }^{[4 \mathrm{c}]}$ 


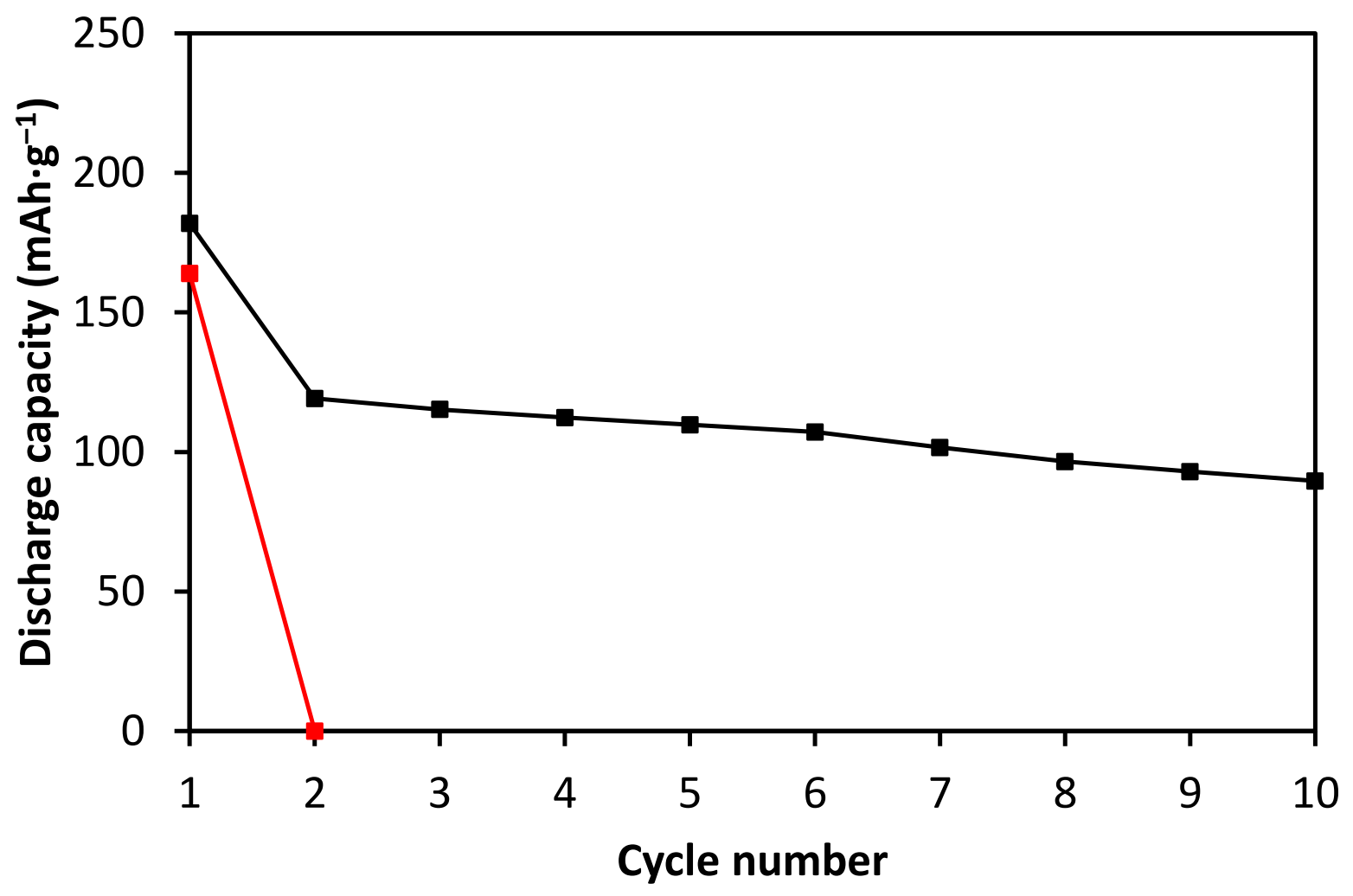

Figure S46. Discharge cycling performance of a rechargeable battery with $0.75 \mathrm{M}$ MMC/G4 (black line) and APC (red line) as the electrolyte, a $\mathrm{Mg}$ anode, and an $\alpha-\mathrm{MnO}_{2}$ cathode under constant current density of $0.2 \mathrm{~mA} \cdot \mathrm{cm}^{-2}$. 


\section{Thermogravimetric Analysis}

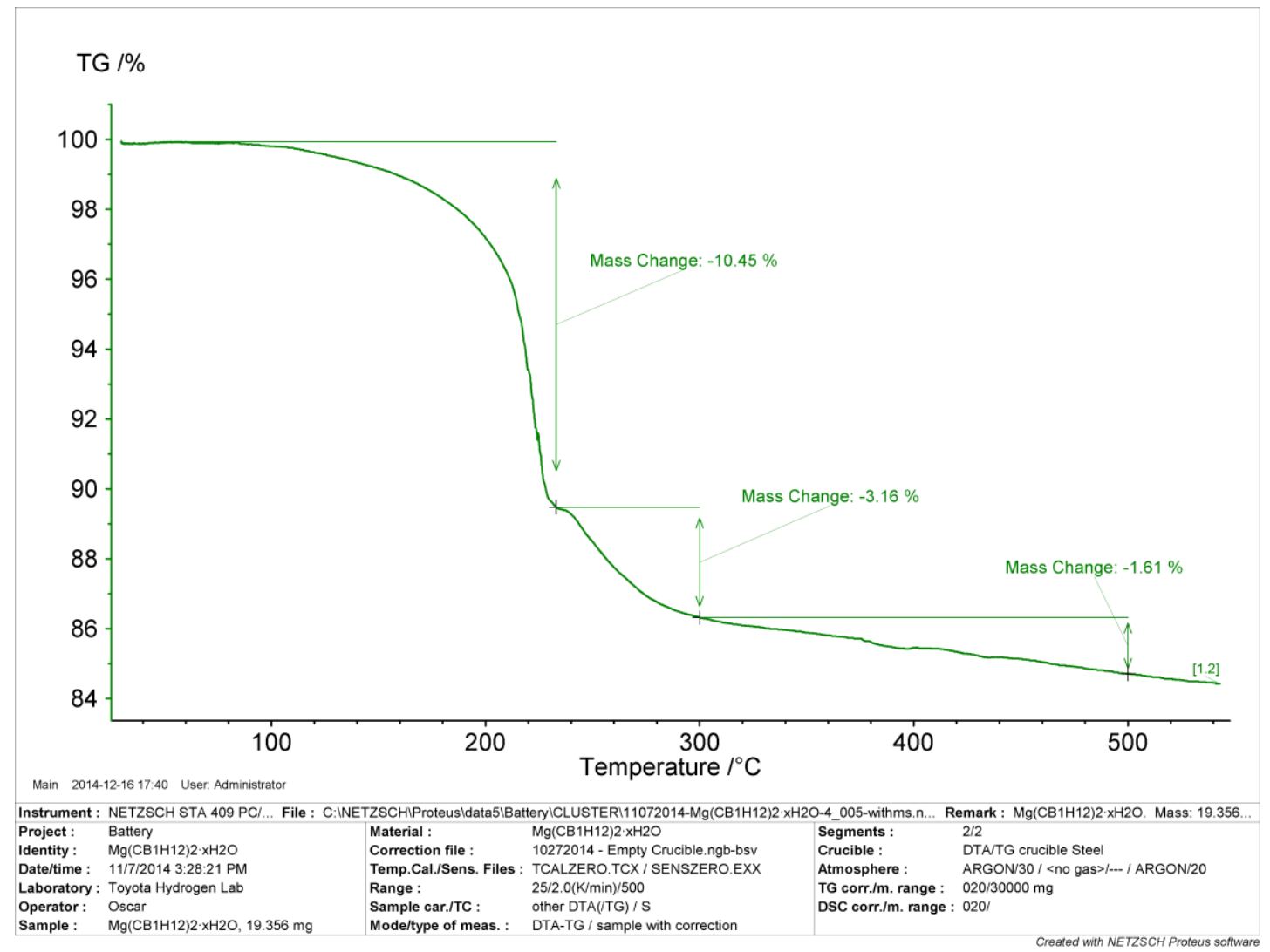

Figure S47. TGA curve of $\left[\mathrm{Mg}\left(\mathrm{H}_{2} \mathrm{O}\right)_{6}\right]\left(\mathrm{CB}_{11} \mathrm{H}_{12}\right)_{2}$ (2).

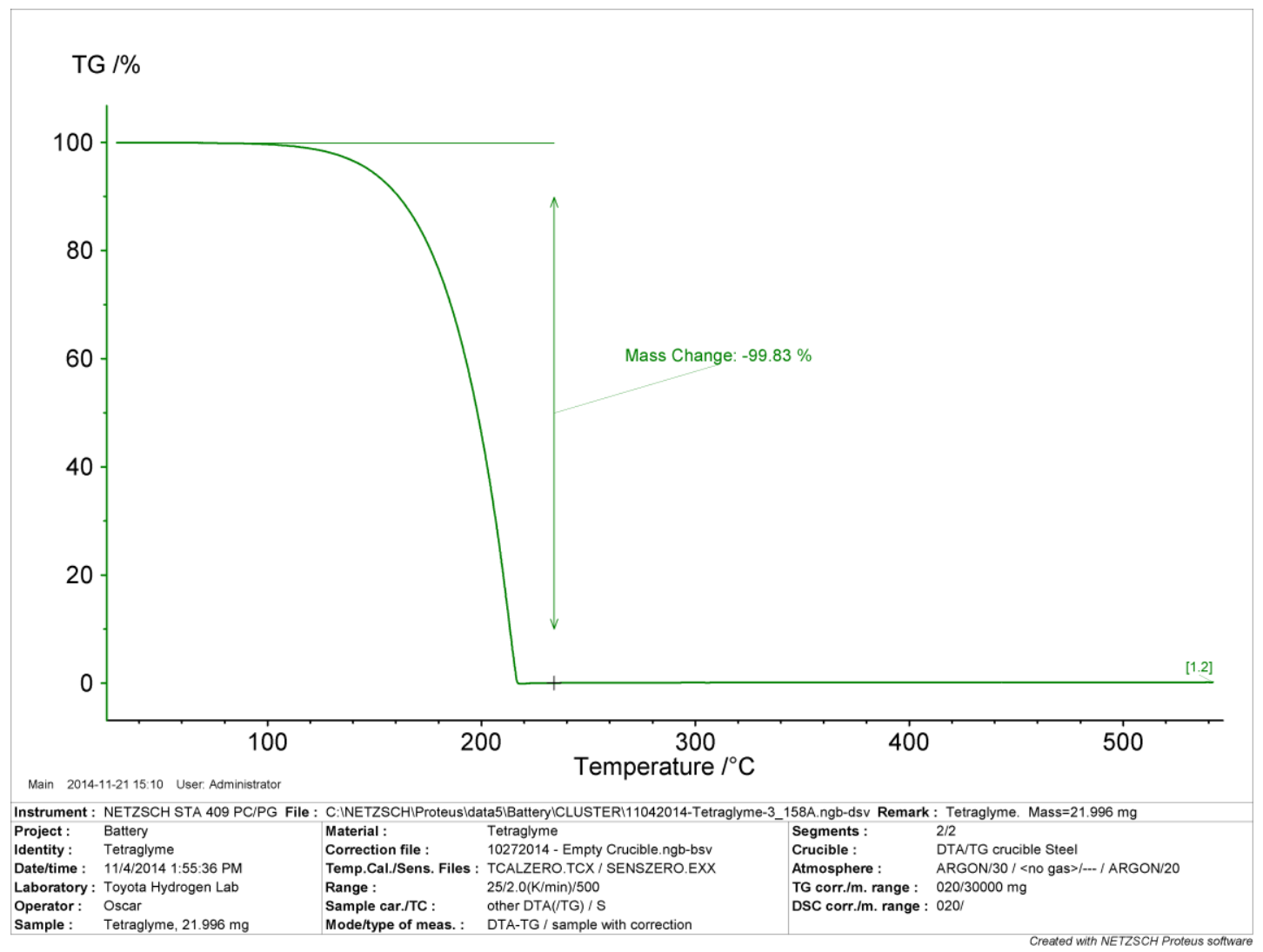

Figure S48. TGA curve of G4. 


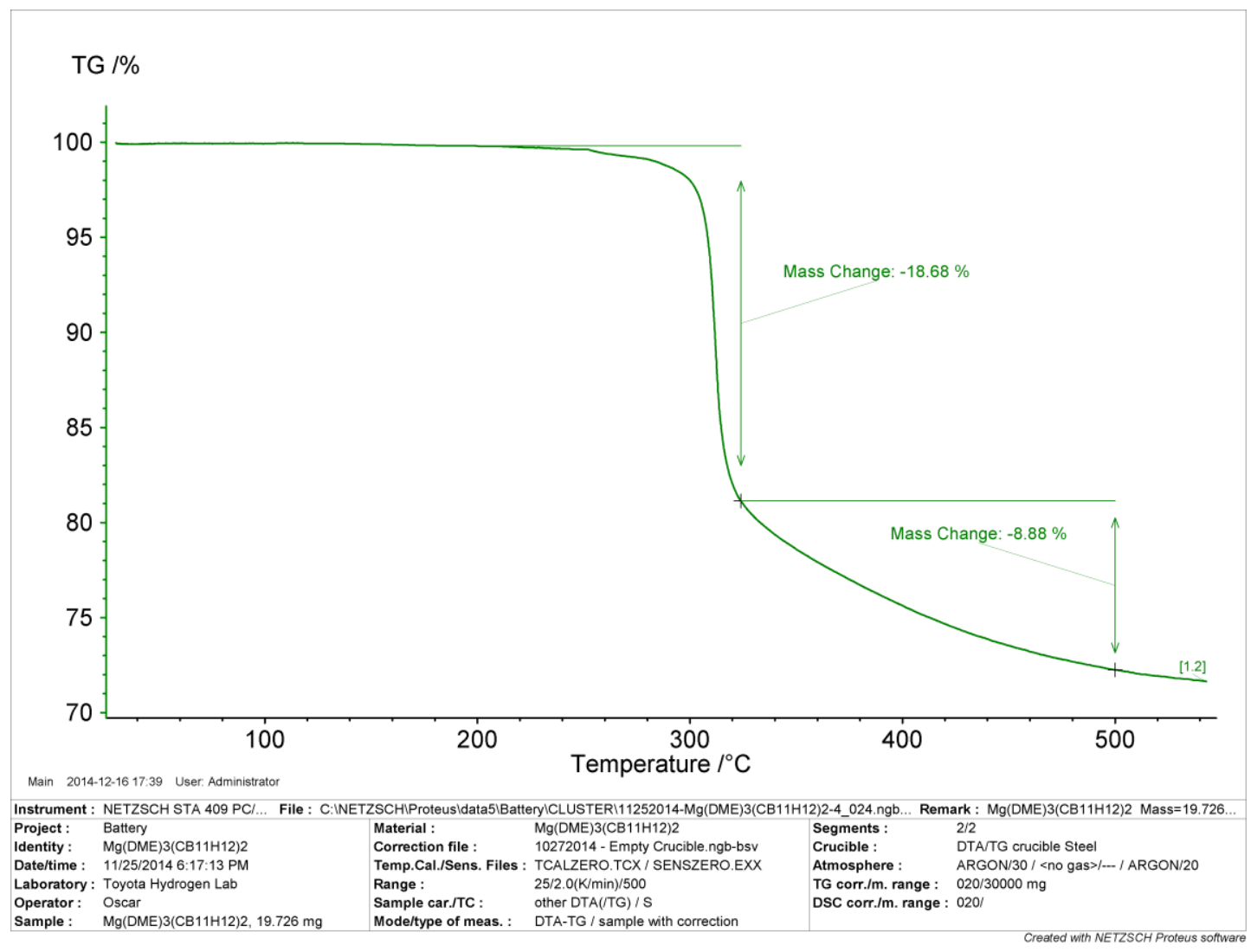

Figure S49. TGA curve of $\left[\mathrm{Mg}(\mathrm{DME})_{3}\right]\left(\mathrm{CB}_{11} \mathrm{H}_{12}\right)_{2}(\mathbf{4})$.

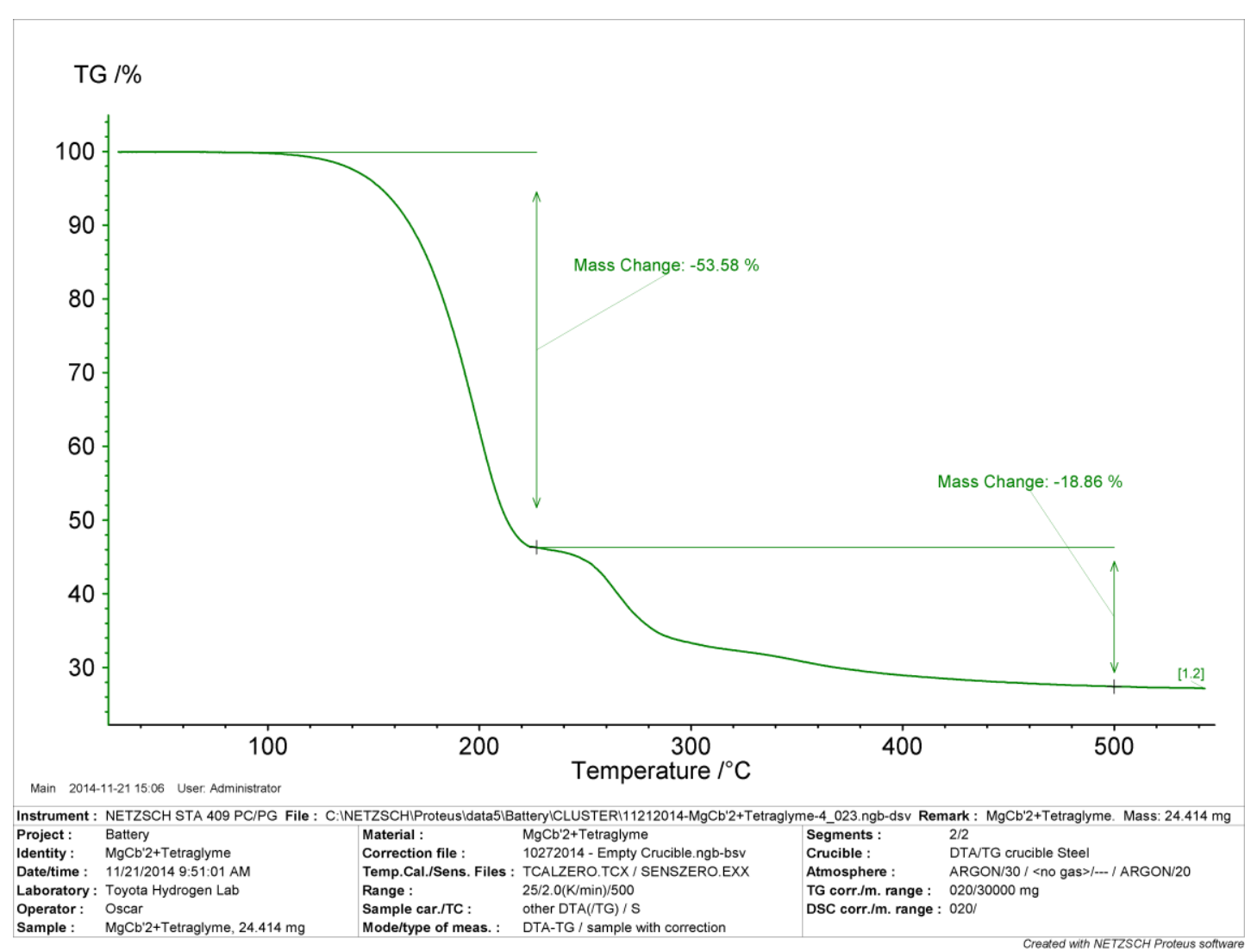

Figure S50. TGA curve of $0.75 \mathrm{M}$ MMC/G4 solution. 


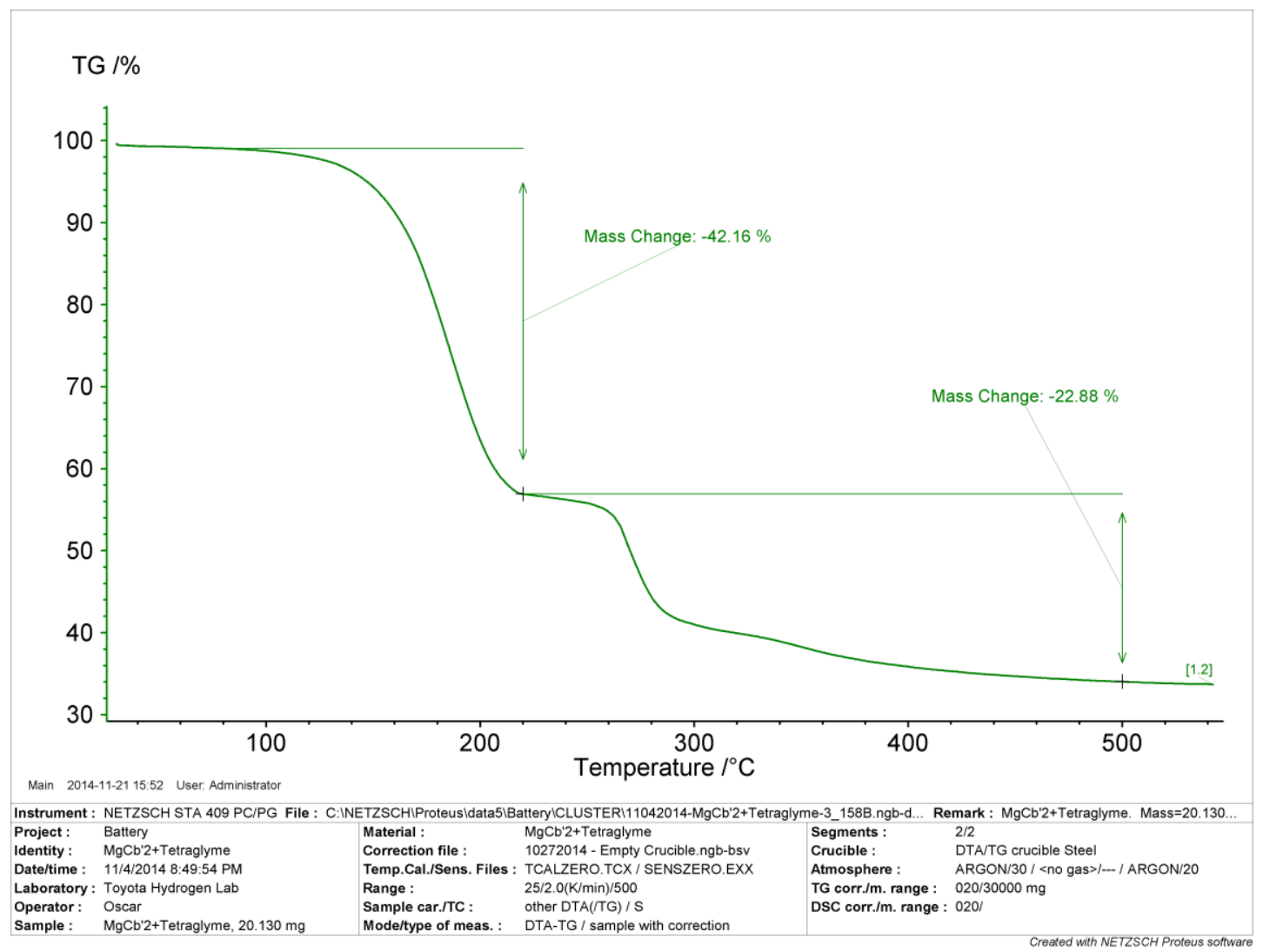

Figure S51. TGA curve of 1.0 M MMC/G4 solution. 


\section{Water compatibility}

Initial water addition $(\mathrm{t}=\mathbf{0} \mathrm{s})$

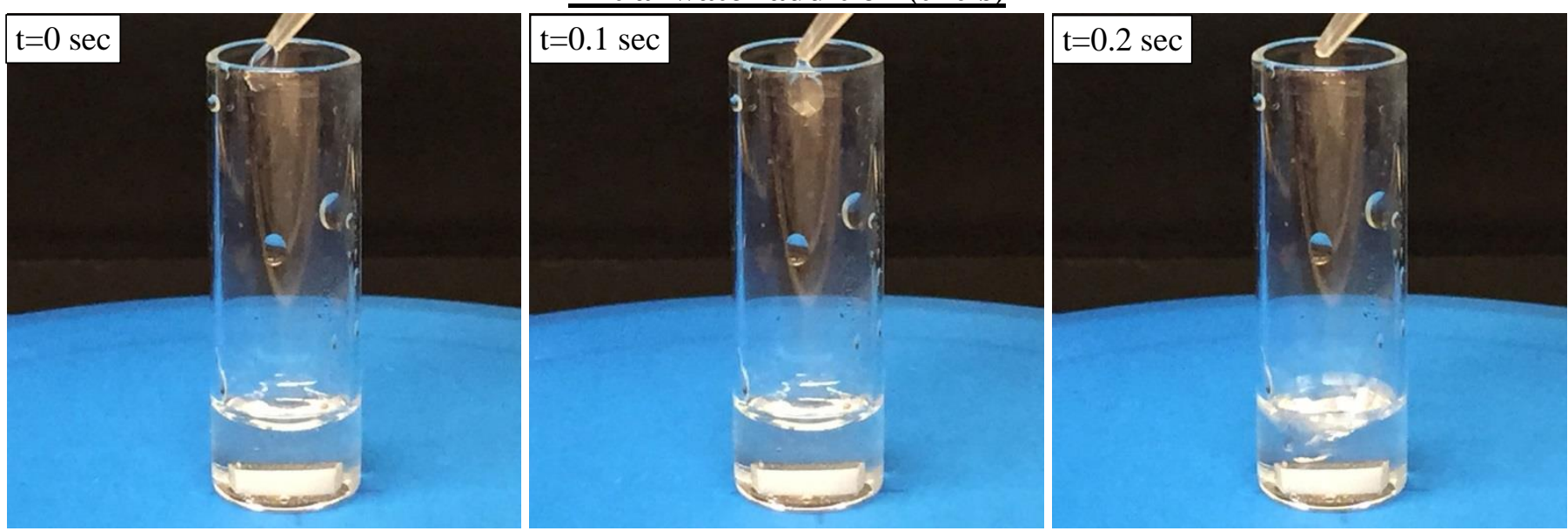

Subsequent water addition $(t=7 \mathrm{~s})$
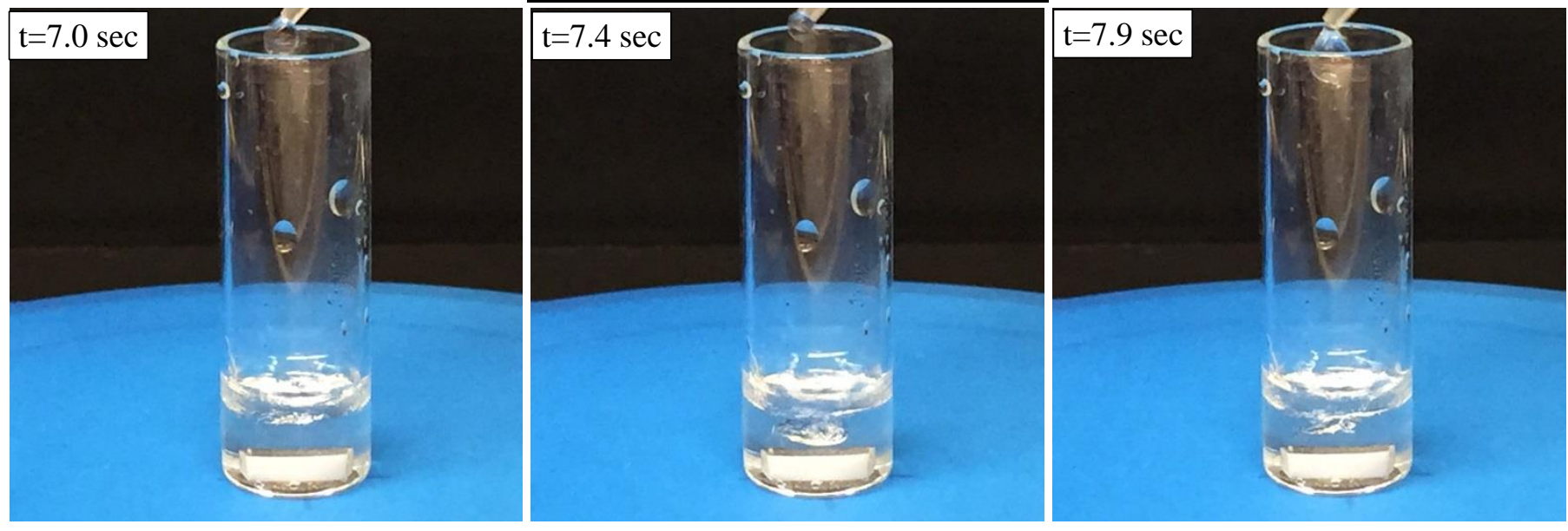

\section{Long term contact with water}

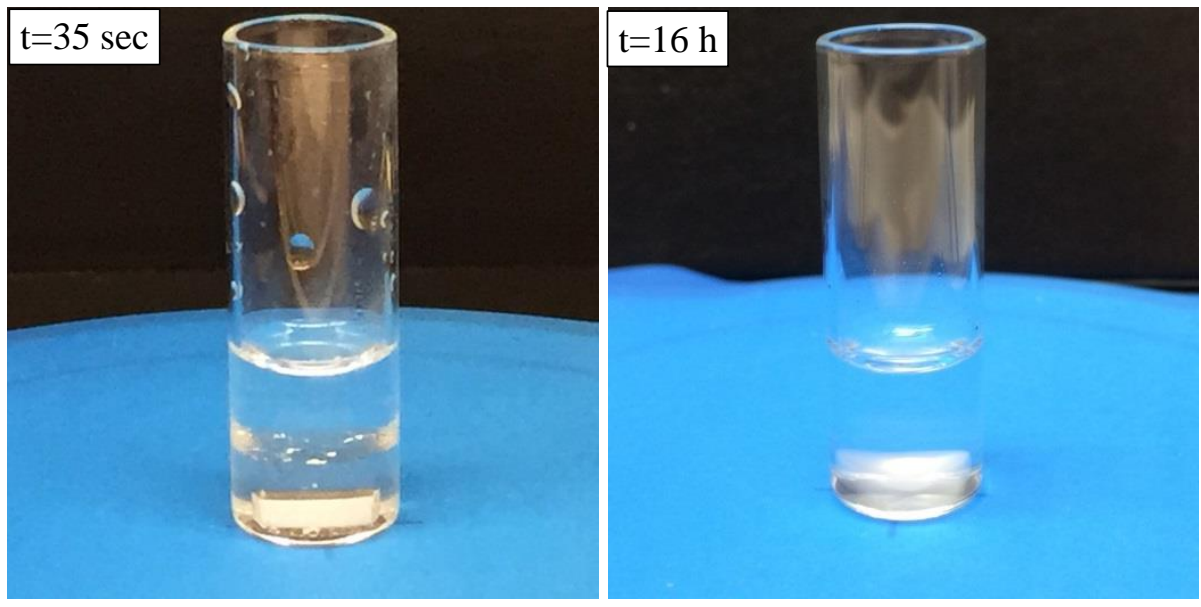

Figure S52. Snapshots of water addition to 0.75 M MMC/G4 electrolyte. 


\section{Supporting References}

[1] K. Shelly, D. C. Finster, Y. J. Lee, W. R. Scheidt, C. A. Reed, J. Am. Chem. Soc. 1985, 107, 5955-5959.

[2] R. K. Harris, E. D. Becker, S. M. C. Menezes, R. Goodfellow, P. Granger, Pure Appl. Chem. 2001, 73, 17951818.

[3] R. Mohtadi, M. Matsui, T. S. Arthur, S.-J. Hwang, Angew. Chem. 2012, 124, 9918-9921; Angew. Chem. Int. Ed. 2012, 51, 9780-9783.

[4] a) D. Aurbach, G. S. Suresh, E. Levi, A. Mitelman, O. Mizrahi, O. Chusid, M. Brunelli, Adv. Mater. 2007, 19, 4260-4267; b) E. Lancry, E. Levi, A. Mitelman, S. Malovany, D. Aurbach, J. Solid State Chem. 2006, 179, 1879-1882; c) E. Lancry, E. Levi, Y. Gofer, M. Levi, G. Salitra, D. Aurbach, Chem. Mater. 2004, 16, 28322838.

[5] G. M. Sheldrick, SADABS 2008/1; Gottingen, 2008.

[6] G. M. Sheldrick, SHELXTL, v 2008/4; Bruker AXS, Inc.: Madison, WI, 2008.

[7] a) L. J. Barbour, J. Supramol. Chem. 2001, 1, 189-191; b) J. L. Atwood, L. J. Barbour, Cryst. Growth Des. 2003, 3, 3-8. 